\title{
A Synthesis Review of Emissions and Fates for the Coal Oil Point Marine Hydrocarbon Seep Field and California Marine Seepage
}

\author{
Ira Leifer $(\mathbb{D}$ \\ Bubbleology Research International, Solvang, CA 93463, USA \\ Correspondence should be addressed to Ira Leifer; ira.leifer@bubbleology.com
}

Received 15 April 2019; Accepted 17 June 2019; Published 17 October 2019

Academic Editor: Umberta Tinivella

Copyright ( 2019 Ira Leifer. This is an open access article distributed under the Creative Commons Attribution License, which permits unrestricted use, distribution, and reproduction in any medium, provided the original work is properly cited.

\begin{abstract}
Anthropogenic oil in the ocean is of great concern due to its potential immediate and long-term impacts on the ecosystem, economy, and society, leading to intense societal efforts to mitigate and reduce inputs. Sources of oil in the ocean (in the order of importance) are natural marine seepage, run-off from anthropogenic sources, and oil spills, yet uncertainty and variability in these budgets are large, particularly for natural seepage, which exhibits large spatial and temporal heterogeneity on local to regional scales. When source inputs are comparable, discriminating impacts is complicated, because petroleum is both a bioavailable, chemosynthetic energy source to the marine ecosystem and a potential toxic stressor depending on concentration, composition, and period of time. This synthesis review investigates the phenomena underlying this complexity and identifies knowledge gaps. Its focus is on the Coal Oil Point (COP) seep field, arguably the best-studied example, of strong natural marine hydrocarbon seepage, located in the nearshore, shallow waters of the Northern Santa Barbara Channel, Southern California, where coastal processes complicate oceanography and meteorology. Many of our understandings of seep processes globally are based on insights learned from studies of the oil and gas emissions from the COP seep field. As one of the largest seep fields in the world, its impacts spread far as oil drifts on the sea surface and subsurface, yet much remains unknown of its impacts.
\end{abstract}

\section{Introduction}

\subsection{Overview}

1.1.1. Motivation. Understanding seepage requires knowledge of the geological and oceanographic controls on its emissions (where and how strong) and then oceanographic and meteorological factors that control its fate (transport and the chemical and biological evolution of seep hydrocarbons). California marine seepage over evolutionary timescales has impacted marine ecosystems both as a chemical stressor and as a chemosynthetic energy source, leading to adaptation at the species and community levels.

In this review, we summarize the state of knowledge of emissions and impacts from one of the most prolific and arguably best-studied natural marine hydrocarbon seep fields, the Coal Oil Point (COP) seep field in the northern Santa Barbara Channel, offshore Southern California, and place it in the general global context of seepage understanding.
The COP seep field lies in nearshore waters $(10-70 \mathrm{~m})$, and thus, its emissions and their fate are governed by transport and weathering in the complex Pacific coastal environment. This synthesis review places context on the role of seep petroleum hydrocarbons in the California coastal marine environment and highlights how current understanding of the COP seep field provides insights into seep processes elsewhere.

1.1.2. Definition of Seepage. Hydrocarbon seepage is the process by which hydrocarbon gases and liquids (fluids) associated with petroleum accumulation in a reservoir layer escape from the lithosphere to the hydrosphere and/or atmosphere. The reservoir layer must be fractured or porous to allow migration within. Critical to seepage is a capping layer that allowed hydrocarbon accumulation over geologic timescales and fractures and/or faults that provide migration pathways within the reservoir and through the capping layer (if not eroded allowing outcropping) to the seabed or atmosphere [1]. 
Natural marine hydrocarbon seepage occurs from intertidal depths (e.g., San Simón Bay, Galícia, Spain) to more than $4,000 \mathrm{~m}$ in the Aleutian Trench and in every sea and ocean [2]. Marine hydrocarbon seeps are termed cold seeps to differentiate them from hydrothermal (hot) systems. Both support chemosynthetic ecosystems and have some similar processes such as buoyant plumes [3]. Hydrothermal systems' hydrocarbons are limited to methane $\left(\mathrm{CH}_{4}\right)$ [4]. Cold seeps primarily emit $\mathrm{CH}_{4}$ but can produce other higher alkanes [2]. Upon reaching the sea surface, the liquid component (oil) if present, forms slicks that drift under the same processes that affect the chemical and physical evolution and transport of oil slicks from oil spills [5]. As a result, marine oil seepage provides a natural laboratory to improve our understanding of oil spill science, e.g., Leifer et al. [6], MacDonald et al. [7], and Thrasher et al. [8].

1.1.3. Seepage and Human History. Natural hydrocarbon seepage is widespread onshore and offshore and has played a notable role in human societies as far back as the Paleolithic when it was used as an adhesive in tool construction [9]. The most famous historical natural terrestrial hydrocarbon seepage lies in and near the Middle East [10], such as the Oracle of Delphi, which has been proposed to relate to hydrocarbon emissions (fumes) from geothermal vents into sacred caves [11] and eternal fires [12]. Eternal fires influenced ancient religions such as the Zoroastrian's [13] and other religions around the fires at Vulcan [10]. Bitumen from middle eastern seeps include the Dead Sea, also known as Mare Asphalticum, where large tar blocks were found floating and on the shore [14]. From these, tar was recovered and traded supporting numerous uses in antiquity, including mummification $[15,16]$. This name derives from the Persian word "mummiya," which means bitumen, an adhesive in jewelry and building mortar, for waterproofing of containers and other objects, for agricultural fumigation, and for medicinal uses [14].

Bitumen supported extensive ancient trade, with modern chemical fingerprinting showing trade routes [17]. Many of these uses, particularly waterproofing of vessels, baskets, and clothing and in jewelry, were practiced by indigenous nations in California [18]. Many terrestrial seeps have diminished due to modern production impacts on reservoir pressure, for example, major seepage near Kirkuk, Iraq, and Mene Grande, Venezuela [19].

1.2. Seepage Significance. Seepage impacts a range of important geophysical and biological processes as well as economic activities. These include the climate, marine carbon cycling, oil spill science, oil spill response, and exploration, discussed below.

1.2.1. Seep Methane Budgets. The important greenhouse gas $\mathrm{CH}_{4}$ has anthropogenic $\left(360-430 \mathrm{Tg} \mathrm{yr}^{-1} ; 1 \mathrm{Tg}=10^{12} \mathrm{~g}\right)$ and natural sources (160-240 $\left.\mathrm{Tg} \mathrm{yr}^{-1}\right)$ of biological [20] and geological origins [13]. The latter includes emissions from natural seepage, estimated in the 1990 s at $8-65 \mathrm{Tg} \mathrm{yr}^{-1}$ globally [21]. $\mathrm{CH}_{4}$ budgets have large uncertainty for many important sources [22] with greater uncertainty in future trends from global warming feedback [23] and increasing anthropogenic activities $[24,25]$.

Fossil fuel industrial (FFI) emissions comprise both anthropogenic and geologic, i.e., ancient $\mathrm{CH}_{4}$ that is isotopically light. The IPCC estimates that geologic $\mathrm{CH}_{4}$ contributes $\sim 20-33 \%$ of the natural budget or $54 \mathrm{Tg} \mathrm{yr}^{-1}$, i.e., 33$75 \mathrm{Tg} \mathrm{yr}^{-1}$ [26]. This is a much larger fraction of the ancient $\mathrm{CH}_{4}$ budget, estimated at $118 \mathrm{Tg} \mathrm{yr}^{-1}$ [27] to $175 \mathrm{Tg} \mathrm{yr}^{-1}$ [28]. This estimate includes marine seepage but not hydrates. Of this value, marine seepage contributes an estimated 20 $30 \mathrm{Tg} \mathrm{yr}^{-1}$ with terrestrial microseepage and mud volcanoes adding 30-55 $\mathrm{Tg} \mathrm{yr}^{-1}$ [29-31]. This estimate also neglects seep $\mathrm{CH}_{4}$ from submerged Arctic permafrost whose emissions could be comparable to all other global marine seepage combined [32]. Note that some Arctic seepage is isotopically light as it arises from thermogenic seepage that is partially sequestered below permafrost.

Estimates of global seep emissions are based on a very limited number of measurements. Fluxes for individual marine seep vents have been reported for the Gulf of Mexico [33], offshore Norway [34, 35], the North Sea [36], offshore Svalbard in the Norwegian Arctic [37], the arctic Laptev Sea [38], and numerous vents in the COP seep field [39].

The COP seep field is the first seep field for which gas emissions were estimated, at $10^{5} \mathrm{~m}^{3} \mathrm{dy}^{-1} \mathrm{CH}_{4}$ in 1995 based on sonar data [40] and in 2018 for the more active portions of the seep field at $2 \times 10^{4} \mathrm{~m}^{3} \mathrm{dy}^{-1}$ [41]. Additionally, sonar has surveyed seep areas in the Black Sea [42], offshore Svalbard in the Norwegian Arctic [43], the deep Gulf of Mexico [44], offshore Pakistan [45], and the East Siberian Arctic Sea [32]. In the latter, bubble modeling and a storm flushing approach was used to estimate area emissions. Video surveys can derive emissions from a constrained area [36]. Leifer [36] estimated emissions for an extremely intense, localized $\left(\sim 260 \mathrm{~m}^{2}\right)$, central North Sea seep area. Additionally, sea-air fluxes derived from concentration and wind measurements have been used to estimate area emissions [46-48] but are less certain due to heterogeneity, not including direct bubble transport to the atmosphere, water column losses, and difficulty in constraining transport, including variability in vertical transport.

Extending seep surveys to annualized emissions is problematic as a survey provides snapshots of geological systems, which exhibit high temporal variability on timescales from the subhourly [49] to decadal [50], although few studies have characterized long-term variability. Most published longitudinal time series have been semiquantitative in terms of flux, e.g., passive acoustics for eight months in the North Sea [51], year-long active acoustics offshore British Columbia [52], air concentrations downwind of the COP seep field spanning two decades [53], and dissolved $\mathrm{CH}_{4}$ for a halfyear offshore Greece [54]. Longitudinal studies are key to characterizing the flux scales associated with temporal variability in seep emissions.

1.2.2. Seep Oil Budget. The two primary marine petroleum sources [55] are natural marine seepage and consumption (Figure 1). Petroleum consumption arises primarily from terrestrial run-off and atmospheric deposition, with minor 


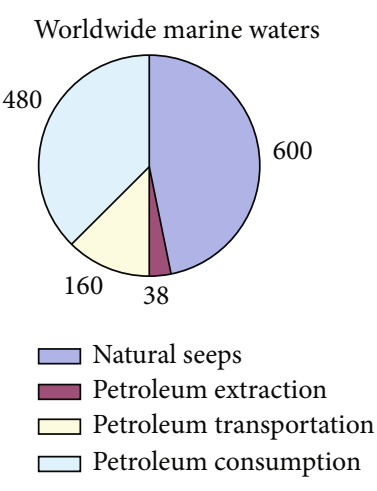

(a)

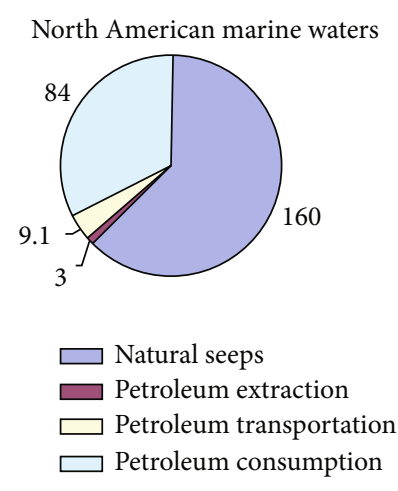

(b)

FIgURE 1: Contribution of average annual oil releases (in ktonnes) for 1990-1999 for (a) the globe and (b) North America. From NRC [55].

inputs from vessel engine operations, riverine run-off, atmospheric deposition, operational discharges, and jettisoned aircraft fuel. The third most important source is from petroleum transportation-both from pipelines and tanker vessels.

Over recent decades, oil transport safety has increased while the amount spilled into the ocean has decreased. As a result, natural seepage plays an increasingly important role in the marine petroleum budget, both globally and regionally. Natural oil seepage is estimated as the largest marine source, estimated by NRC [55] as between 200,000 and 2,000,000 tons $\mathrm{yr}^{-1}$ globally and from 80,000 to 240,000 tons $\mathrm{yr}^{-1}$ for North America. Despite its importance, published measured fluxes largely are lacking with an absence of time series studies. Thus, global estimates are from known petroleum global reservoir size and estimated leakage rates on geologic timescales [56].

There are two published quantitative oil emission estimates for a seep field or region as opposed to a single vent. One is for the COP seep field [40] estimated at $100 \mathrm{bbl}$ oil day $^{-1}\left(5,000\right.$ tons $\left.\mathrm{yr}^{-1}\right)$ or $2-6 \%$ of the North American total. Hornafius et al. [40] derived this oil estimate from a sonar estimate of gas seepage and an estimated oil to gas ratio. The Hornafius et al. [40] estimate was similar to an estimate of $50-70 \mathrm{bbl}$ oil day $^{-1}$ in 1970 from aerial imagery and assumed oil slick thickness [57].

A second value was published more recently for the Gulf of Mexico and found 2.5-9.4 $\times 10^{4} \mathrm{~m}^{3} \mathrm{yr}^{-1}$, equivalent to 22,500-85,500 tons $\mathrm{yr}^{-1}$ [58], compared to the NRC [55] estimate for all of North America of 80,000 to 240,000 tons $\mathrm{yr}^{-1}$. MacDonald et al. [58] investigated (in remote sensing data) a portion of the active seeping regions of the Gulf of Mexico. Thus, the MacDonald et al. [58] study provides a check on global and regional estimates, suggesting that the NRC [55] range is conservative. However, uncertainty remains very large both due to methodological uncertainty (parameterizations that have not been field validated) and as the studies were highly limited in space and time.

Accidental tanker spills, which in the 1970s released oil quantities comparable to seepage (320,000 tons $\left.\mathrm{yr}^{-1}\right)$, contributed just 3,900 tons $\mathrm{yr}^{-1}$ for the period 2010-2016 [59]. This figure neglects pipeline leaks including the Deepwater Horizon spill, which released 450,000 tons $[60,61]$, and nonacci- dental spills from war, such as during the Iraq war in Kuwait [62]. No medium or larger ( $>7$ tons) tanker spills have been reported in California waters in the ITOPF [59] data, which extends back to 1970 .

1.2.3. Seeps and the Marine Ecosystem. Seep petroleum hydrocarbons (including oil and natural gas) provide bioavailable chemosynthetic energy [63], which for the lowest trophic levels (microbial) have been extensively researched, e.g., see review in Levin [64]. In the case of deep sea seep chemoautotrophic ecosystems, the vast majority (to $100 \%$ in lower trophic levels) of energy derives from nonphotic sources. Seep emissions contribute to higher trophic levels, e.g., from over 3,000 $\mathrm{m}$ deep $\mathrm{CH}_{4}$ seepage off the Congo [65] and for oil and gas seepage in the Gulf of Mexico [66]. Deep sea, cold seep microbial communities support localized, rich seep ecosystems in a similar manner as for hydrothermal vent ecosystems $[3,64,67]$, with shared evolutionary histories [68]. Seep communities include predatory and opportunistic feeders such as shrimp, crabs, and fish that range over large distances $[3,65,69]$.

Impacts from cold seep ecosystems extend beyond the seepage area by mobile upper trophic-level species [64], larval dispersion [68], microbial dispersion [70], and current transport of chemoautotrophic primary productivity (waste), $\mathrm{CH}_{4}$, and other petroleum hydrocarbons. Yet, the mechanisms and contribution to the marine ecosystem outside the seep environs remain poorly studied at best, both in the deep sea and more so in shallower waters [71]. Cold seep ecosystems are highly localized, potentially dominating carbon cycles on local scales while also contributing significantly on regional scales [71].

In cold seep ecosystems, the spatial distribution of bacterial mats and microbial symbiont-bearing species, such as tube worms, varies with chemical indicators $\left(\mathrm{CH}_{4}\right.$, sulfur, reducing activity, oxygen content, etc.), including transport by currents [72], and the presence of seep-associated substrates $[73,74]$. Note that these substrates may match current or historical seepage. Diversity decreases away from the center of the seepage [75].

Both the presence of the chemosynthetic source and its chemical stresses are important to the community structure. Thus, within habitat patches along geochemical gradients, 


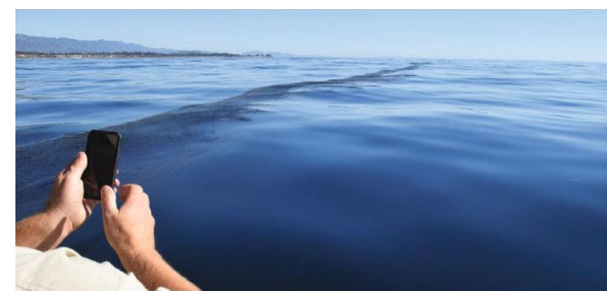

FIgure 2: Thick oil slick from the Coal Oil Point (COP) seep field. This slick stretched for kilometers. Similar COP slicks have been used for spill science, including dispersant tests [91] and studying oil slick advection [6]. Photo: Ira Leifer.

species self-sort, creating complex and heterogeneous community assemblages, while dispersal efficiency and species competition drive community succession [76]. For example, oxygen content, which can be significantly depressed in coastal and continental shelf waters, influences microbial community composition and richness and higher trophic levels, e.g., Hydrate Ridge offshore Oregon [77, 78]. Guilini et al. [77] suggested that oxygen stress selects for species that can colonize cold seeps, adapting to sulfidic conditions.

Associated, higher trophic level species are found clustered around cold seeps but with ranges that extend beyond the seep area's geochemical footprint [3], significantly in the case of top predators [71]. Still, chemosynthetic-dependent megafaunal and macrofaunal communities do not extend far beyond the seep area [75]. For example, a seep-colonization field experiment of sulfide-enhanced trays was most successful in proximity to the seep habitat [79]. In fact, the presence of dense and species-rich aggregations of megafauna is considered one of the best indicators of natural seepage [76].

The importance of seep-related substrate, typically authigenic carbonates, is significant to the diversity and richness of seep ecosystems [2], a role that can be filled by other substrate materials. For example, recent observations of asphalt seepage without active gas or oil emissions found assemblages of nonchemosynthetic megafaunal organisms [80]. Specifically, a rich diversity of megafauna, including sponges and gorgonians, was observed for asphalt seeps off Brazil at 2,700 m depth. There was no evidence of the authigenic carbonates that are indicative of prior microbial oxidation of $\mathrm{CH}_{4}$ seepage, and the isotopic signature of recovered sponges was distinct from that of asphalt. Asphalt is deficient in the light $n$-alkanes that can support chemosynthetic primary producers.

In shallower $(<400 \mathrm{~m})$ water, "normal" organisms that rely on energy derived from the photic zone tend to outcompete seep-specialist organisms [67] although typical seep species are found at strong shallow seeps [81]. For infaunal species, seeps are oases with high population density compared to the surrounding seabed, albeit at reduced species diversity $[69,75,82]$. Despite the toxicity of seep hydrocarbons, macroinfaunal densities can be higher than the surrounding seabed [83].

1.2.4. Seeps and Spill Science. Oil spill response depends strongly on spill models that include characterizations of a wide range of oil spill processes that vary on day to week timescales. These processes include wind and wave advection, spreading and surface diffusion, compression from waves and currents (into wind rows or narrow slicks), sedimentation and dissolution into the water column, emulsification, dissolution and evaporation, and photochemical and biological degradation [55]. Understanding oil spill processes is based on the laboratory [84], large tank [85], and windwave pool [86] studies, planned release experiments, and observations during planned and accidental oil spills [87-89]. However, oceanographic processes are on scales not reproducible in even large wind-wave tanks, regulatory approval for planned releases is challenging to impossible, and the focus during an oil spill is not scientific investigation [90].

Natural marine oil seepage and slicks (e.g., Figure 2) provide an opportunity to improve understanding of oil spill processes without the need for release permits. Both seep oil and spilled oil evolve under the same processes. Natural seepage provides opportunities for repeat studies and experiments under a range of real-world oceanographic and meteorological conditions [6]. Oil seepage provides an opportunity to field test new spill observational approaches [6] and response technologies [91]. Unlike planned releases or tank studies, the persistence of natural seepage allows the study of marine oil slick processes that require time on larger size scales to achieve a steady state.

1.2.5. Seepage and Petroleum Exploration. The modern oil industry largely began in Pennsylvania in 1859 with a well drilled into an oil spring (e.g., a terrestrial hydrocarbon seep) that had been used previously by the Seneca Indians and early settlers [92]. Since then, oil prospecting has used natural seeps in every petroleum-bearing province to help locate oil production [93]. With regard to offshore prospecting, California played a pioneering role; the first offshore oil facility was constructed in the 1890s in nearshore waters of Summerland, CA, in the northern Santa Barbara Channel [94], an area of natural seepage [95]. A range of seepage signatures have been used for marine oil exploration, including the presence of pockmarks and chemosynthetic communities, summarized in Thrasher et al. [8].

\subsection{Geologic Controls on Seepage}

1.3.1. Conditions for Seepage. Marine hydrocarbon seepage occurs where hydrocarbons escape from a reservoir formation that is capped by a relatively impermeable rock layer, which allows hydrocarbon accumulation, along migration pathways to the surface through the capping layer and overlying sediments [96]. Thus, seabed seepage is evidence for both an underlying reservoir and migration pathways. Hydrocarbon accumulation often occurs in anticlines and other traps [97] and reflects upward migration through the reservoir formation. For low permeability reservoir rock matrices, migration in the rock formation tends to be updip along bedding planes, crossing them where faults and fractures present a more vertical pathway [98]. Active migration also occurs at the nonconformity between the reservoir formation and the overlying capping layers [96]. Where the capping layer has 
been eroded away, the reservoir outcrops. Tar biodegradation can block migration pathways, trapping hydrocarbons by forming tar seals [99].

Seepage occurs through the capping layer and overlying sediments, migrating to the seabed along faults and fractures in these layers $[96,100]$. In these geological settings, foldand-thrust fault belts play an important role in fluid migration from deeper layers through faults and fractures, as does accumulation in anticlines [101, 102]. Furthermore, the widespread occurrence of pockmarks suggests that wherever active source rocks occur, there is some sort of seepage of the light hydrocarbon gases (methane-propane). The reason is likely that these gases represent the lightest substances in the entire sediment column (besides hydrogen and helium). These small molecules likely find a pathway to the seabed, even through thick clay layers $[2,103]$.

1.3.2. Spatial Geological Control on Seepage. Marine seepage occurs on all continental shelves, spanning geological settings from passive margins (e.g., riverine deltas, like the Mississippi or Nile Rivers, which deposit organic materials in thick sediment layers) to convergent and divergent plate boundaries where sediments are buried in subducting sediments, to transform plate boundaries (e.g., the Pacific California coast). In the latter, compression from tectonic stresses pressurizes sediments [104], which combines with heat that ultimately converts organic material (kerogen) into petroleum in the source rock [96]. Ultimately, the seal rock fails under tectonic stresses, creating fractures that allow hydrocarbon breakout. The breach eventually selfseals [105] by tar deposition from hydrocarbon migration or compressional tectonic stresses. This breakout and sealing process repeats. For example, thousand-year cycles in passive margin basins like the Gulf of Mexico are observed [106]. In some transform plate boundaries, source rock layer deformation can allow migration up to shallow, capped reservoirs and the seabed [102].

Many authors have noted a relationship between seepage and geologic structures $[1,2,97,107,108]$, including faults, diapirs, outcrops, and slumps. Near-seabed geologic structures such as authigenic carbonates [109] and low permeability sediment layers like clay [110] and ancient river valleys [38] also provide spatial control. These structures relate to low permeability migration pathways and/or allow for hydrocarbon accumulation. One exception is where the reservoir rock layer outcrops (i.e., the overlaying capping layer has been eroded away). As a result, geological structures provide first-order control of the spatial distribution of seepage and its magnitude [39]. Underlying these structures are tectonic factors; for example, mud volcanism most commonly is associated with compressional settings [111].

Sediment overburden can be a major factor in the seepage spatial distribution, particularly in accretionary settings like the Gulf of Mexico where sediment layers are kilometers thick [100]. In such areas, sediment structures such as salt diapirs and fractures provide control. For thin sediment overburdens such as for the COP seep field, sediment controls on individual vent locations are minimal with vents manifesting within short distances from the underlying fractures and faults in the underlying rock [112]. Sediment structures that divert and block seepage include oil and tar [112].

Migration pathways through sediment can be highly variable, unlike pathways through fractures in rock layers. Where sediments are coarse-grained, emissions show similarity to percolation beds as used in chemical engineering with seepage appearing to shift rapidly and randomly between semistationary vents $[36,70,112,113]$.

1.3.3. Seepage Temporal Variability. Seepage is driven by a pressure difference between the reservoir and the seabed (above hydrostatic) along multiple migration pathways with higher seepage associated with higher permeability pathways. One approach to describing this complex system is a seep electrical (SE) model (Figure 3), described in Leifer and Boles [114] and Leifer and Wilson [115]. In the SE model, fluid dynamic processes are represented by electrical circuit components. Thus, voltage (pressure) drives a current (flow) through a resistor (permeability) with resistance, $R$. The Zener diode reflects that migration must exceed a flow rate greater than the microbial (oxidation) filter (e.g., [116]), preventing $\mathrm{CH}_{4}$ emissions. Where permeability is very low (very high resistance), current does not flow and there is no seepage. A capacitor with capacitance, $C$, represents the volume of the migration pathways and shallow reservoirs. Thus, one implication of the SE model is that a seep system has natural response timescale $(R C)$, which responds to changes in the forcing, such as from tidal hydrostatic pressure. The SE model describes how seepage balances between different migration pathways based on relative pathway permeability.

Seepage is pressure-sensitive with emissions finely balanced between near-seabed reservoir recharge from below and discharge to the seabed. This drives a highly nonlinear response of seepage to changes in seabed hydrostatic pressure, with the sensitivity inversely related to flux [49].

For example, consider decreasing hydrostatic pressure, which leads to increased emissions. The increased emissions discharge the near-seabed reservoir until it is depleted. Meanwhile, deeper recharge eventually achieves a new equilibrium. Higher emissions also increase resistance through the active migration pathways in a negative feedback that limits the increase in emissions, analogous to resistive heating. Because the driving force remains, this emission self-limits, maintaining the hydrostatic overpressure thereby allowing activation of inactive migration pathways with higher $R$. The entire process reverses with increasing hydrostatic pressure. Thus, there are two timescales, depressurization of the shallow reservoir, which is based on the volume (or capacitance) and flow, and a second timescale associated with the pressure forcing from swell or tides, i.e., one would expect the strongest sensitivity where the seepage $R C$ and forcing timescales match.

There is asymmetry in the seep response to changing hydrostatic pressure. Specifically, decreasing pressure leads to a greater increase in emissions than increasing pressure decreases emissions. The underlying mechanism is unknown but could have an elastic component-higher flow and pressure open bottlenecks, decreasing migration pathway 


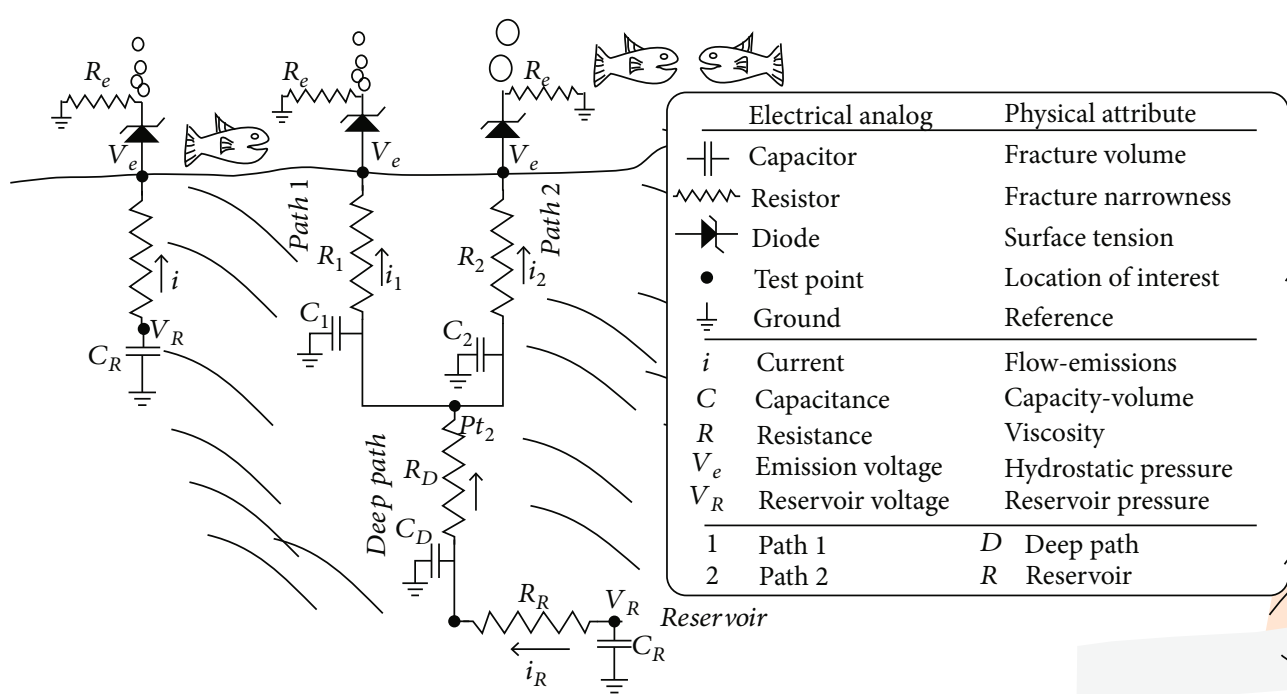

(a) (b)

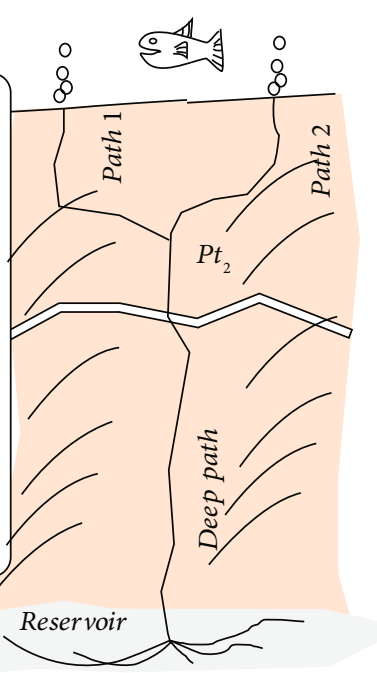

(c)

FIGURE 3: Seep electrical model for a simple seep area. Table defines the physical seep flow process and corresponding electrical component. Adapted from Leifer and Wilson [115].

resistance to flow, further increasing the flow. To summarize, waves pump emissions [51].

1.3.4. Spatial-Temporal Connectivity. Geological structures affect the details of hydrocarbon seepage to the seabed; thus, seepage from different seep vents can be hydraulically related [103]. A number of studies have documented that temporal changes and spatial changes are related $[49,53]$ due to subsurface connectivity of migration pathways. Thus, emission changes at one vent correlate more strongly with changes at vents that are closely connected and less strongly for vents that are less closely connected.

Generally, seepage is not zero sum (i.e., just shifting between vents). This is illustrated in Figure 4 where a migration pathway from a shallow reservoir becomes partially blocked (red to blue for Vent 2) causing its emissions to decrease ( $R_{\text {shallow } 2}$ increases and its current decreases). This leads to an increase in the shallow reservoir's pressure $\left(V_{\text {shallow }}\right)$, which has capacitance, $C$. The increased pressure drives greater flow through other connected migration pathways-with a greater increase for higher flow vents (Vent 3), which have lower resistance, than that for weaker vents (Vent 1). The shallow reservoir is recharged by flow from a deeper source. This recharge is reduced slightly of the overall increased resistance in $R_{\text {shallow2 }}$ and the slightly increased resistance in Vents 1 and 3 from the higher flow. The electrical analogy is that the higher flow through Vents 1 and 3 heats these resistors, causing the resistance to increase. These nonlinearities argue that blockage is not zero sum on overall emissions from interconnected seeps.

In the above discussion, emissions from the shallow reservoir change from changes in migration resistance (or permeability) between the shallow reservoir and the seabed or from seabed (hydrostatic) pressure changes. These changes in emissions and permeability drive the interplay between vents. In contrast, the effect of a change in migration flow or resistance from the deep source that feeds the shallow res- ervoir is different. Here, an increase in flow to the shallow reservoir also increases seabed emissions. However, higher flow in these pathways increases the resistance, i.e., seabed emissions increase less than the increase in flow from below. This increased pressure in the shallow reservoir partitions the increased flow among all migration pathways to the seabed, favoring larger vents, and/or by pathway activation until inflow and outflow from the shallow reservoir balance. This mechanism was proposed to explain long-term seep emission trends in the COP seep field reported by Bradley et al. [53]. Bradley et al. [53] observed that for periods when seepage was low, seepage was constrained to the core of the seep field, whereas for periods of strong seepage, seepage was more extensive.

For seepage through unconsolidated sediment, emissions are far more variable and sporadic, often transient, with high variability in the migration pathways. This is akin to a chemical engineering trickle bed. In this case, the absence of a shallow reservoir where pressure can build up (or draw down) prevents communication between vents, i.e., emissions remain uncorrelated. This uncorrelated behavior was observed by Greinert [117] in the Black Sea and proposed for North Sea seepage at the 22/4b blowout site by Leifer [36] and for emissions through loose sand in the COP seep field [70]. In the latter case, there was an absence of bacterial matts and/or oil seepage that could have cemented sand grains. Given the absence of a shallow reservoir in unconsolidated sediments, seepage likely is zero sum in such settings.

1.3.5. Seep Emission Characteristics. Hydrocarbon seepage escapes the seabed as individual bubbles, bubble streams, bubble plumes, or intense megaseep (order $10^{6} \mathrm{Ldy}^{-1}$ or greater) bubble plumes (Figure 5). The latter generally arise from the merging of numerous seep plumes. Seabed seepage tends not to escape as a dissolved fluid because of the microbial filter, which is highly efficient at oxidizing aqueous $\mathrm{CH}_{4}$. This mitigates marine $\mathrm{CH}_{4}$ microseepage [116], which is 


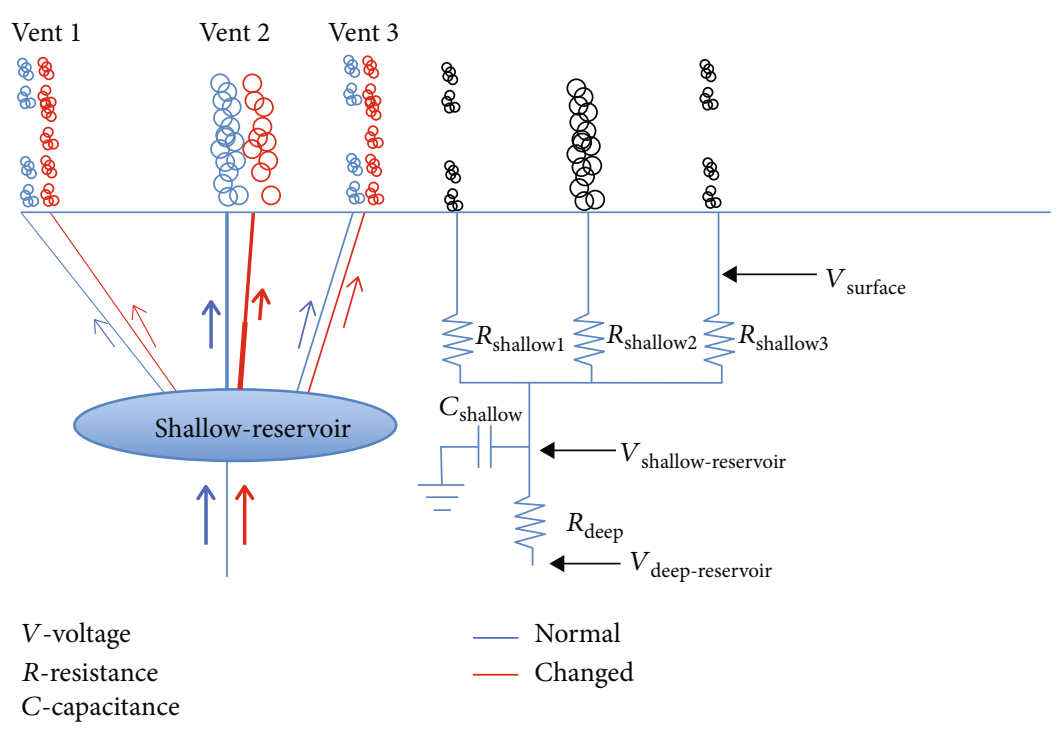

FIGURE 4: Seep electrical model schematic illustrating effect of blockage in one of multiple migration pathways from a shallow reservoir, which is fed from a deeper source. Arrow thickness indicates the flow rate.

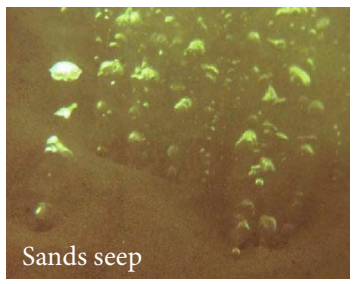

(a)

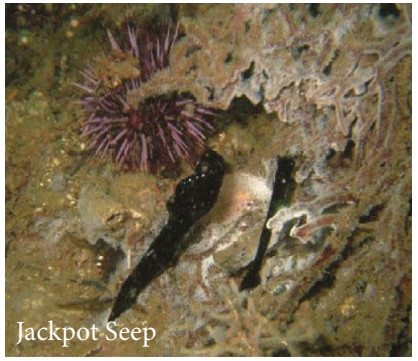

(d)

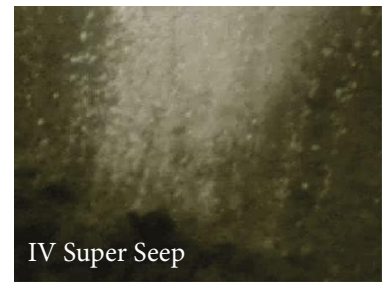

(b)

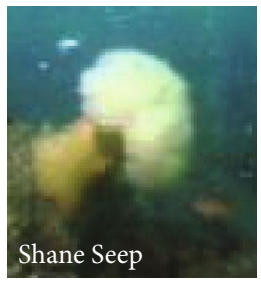

(c)

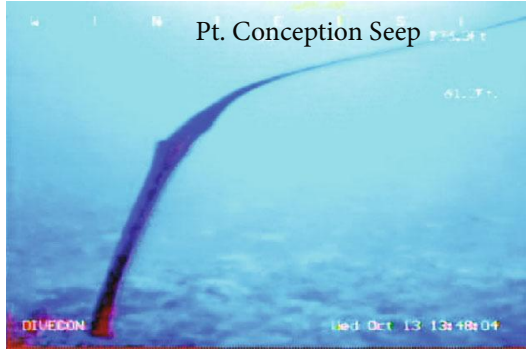

(e)

FIGURE 5: Example images of (a) mobile sediment seepage including many minor bubble plumes, (b) a megaseep where emissions arise from numerous vents that combine into a single bubble plume, IV Super Seep, (c) obstructed seep that leads to bubble aggregation into very large bubbles from Shane Seep, and (d) oil seepage from Jackpot Seep in $10 \mathrm{~m}$ water depth. From Leifer [39]. (e) Tar whip from off Point Conception. From Lorenson et al. [125].

common on land [118]. Bubbles bypass the microbial filter. Most studies have reported on single bubble streams, e.g., Sauter et al. [35], or single bubbles, e.g., Salmi et al. [119].

The fate of seep bubbles and their impact strongly depend on bubble size and seabed depth. Bigger and shallower bubbles [120] and oily bubbles [7] are more likely to reach the wave-mixed layer and sea surface. Sufficiently large bubbles can reach the sea surface with a significant fraction of their $\mathrm{CH}_{4}$ from hundreds of meters [121] to even a kilometer deep [122].

For bubble flows below a critical flow rate, bubble size depends on orifice size while for flows above the critical flow rate, bubble size depends on both orifice size and flow rate [123]. At flow rates significantly greater than the critical flow rate, the gas escapes the seabed as a jet that fragments into a spectrum of bubble sizes [124], which relates to turbulence scales. Where seep bubbles escape through unconsolidated sediment, there is an inverse relationship between grain size and bubble size [124]. Leifer and Culling [124] proposed that this arises from greater gas retention with finer grain size. Also, bubble size is inversely proportional to cross-flow speed [114].

Any plume type can contain oily bubbles; however, identifying oily bubbles by appearance can be difficult (except for very oily bubbles). Thus, the presence of oil is inferred from 


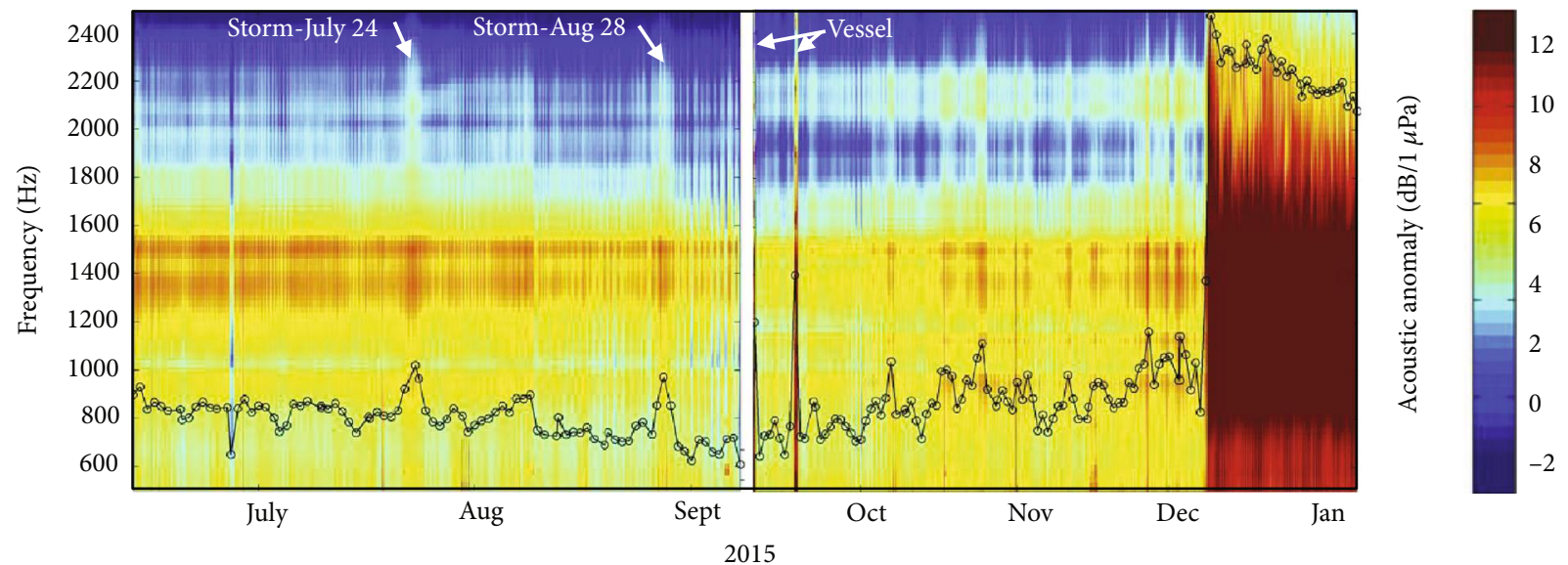

FIgURE 6: Long-term acoustic spectral observations for the North Sea 22/4b seep site and daily average (right axis). Fine striations (subdaily) are tidal emission variations. The acoustic spectrum relates to the bubble size spectrum. The September data gap reflects retrieval and deployment of a second recorder. From Wiggins et al. [51].

slowed bubble rise [39] or surface oil slicks (which require sufficiently calm seas). Hydrocarbon seepage also can escape as liquid oil (no bubbles) droplets, tar slugs, or tar whips $[50,125]$.

As bubbles rise, their contents- $\mathrm{CH}_{4}$, higher alkanes, and other trace gases [126], including volatile oil components [60]-dissolve into the water column. This loss is preferential for lighter gases and more soluble gases, leading to enhancement of larger and less soluble gases in the bubble. Due to their greater buoyancy, bubble rise speeds are orders of magnitude faster than for similar size oil droplets [127], i.e., vertical bubble-mediated oil transport is markedly more rapid than bubble-free oil droplet rise. This significantly reduces water column transit time. If seep bubbles are in a narrow size range, then dissolution occurs in a thin layer where remnant trace gases can be deposited [128] along with transported oil and other adsorbed, surface-active compounds and substances. Rising oil droplets may lose buoyancy by incorporation of water (emulsification) and sediment (mineralization) leading to horizontal drift or even sinking.

Synergies allow bubbles in a plume to rise higher, retaining more of their initial gases to shallower depths or the sea surface. The most important synergy is the upwelling flow, where a fluid flow is driven by the bubbles' buoyancy [129]. For megaseep bubble plumes, the upwelling flow can be significant—-to a meter per second [113].

1.3.6. Temporal Variability in Emissions. Seep emissions vary on second [130] to hourly [49] to diurnal [131] to decadal [50] timescales due to many factors, including swell, tides, and storms. In addition, seeps can be transient, with bubbles escaping in pulses lasting seconds to minutes [70, 117]. In unconsolidated sediment, this may arise from subsurface pathway shifts $[36,112]$ and shallow accumulation until elastic failure creates transient emissions [132]. This introduces significant uncertainty in annualized emissions. Only a few longitudinal studies (outside the COP seep field) have been published. A 13-month time series was collected for offshore British Colombia in $1250 \mathrm{~m}$ deep water [52], 24 hours for Hydrate Ridge in 790 m, offshore Oregon [133], 8 months for the North Sea in $100 \mathrm{~m}$ [51], and 19 days in 3-5 $\mathrm{m}$ water in the South China Sea [134].

The first reports of tidal forcing of seep emissions were in the COP seep field for seep oil emissions [135], for oily bubble plumes [131], and for oil and gas emissions from a shallow abandoned well offshore Summerland, California [115]. Tidal forcing has been observed for seepage elsewhere, including the North Sea from $120 \mathrm{~m}$ (Figure 5) and in deep water $(1,250 \mathrm{~m})$ offshore British Columbia [52]. In shallow water, tidal forcing arises primarily from hydrostatic pressure fluctuations $[131,134]$ based on tent data sealed against the seabed. Earth tides have been proposed to affect an analogous geological migration system (geysers) [136], although recent studies on Yellowstone geysers found no relationship [137]. Swell hydrostatic forcing of seepage occurs on shorter subtidal timescales, i.e., seconds to tens of seconds, at least in the shallow COP seep field $[49,70]$. Both hydrostatic pressure changes and near-seabed fluid motions contribute [114].

Seasonal trends have been identified in the North Sea passive acoustic data (Figure 6), in decadal long COP seep field air quality data [53], and in deep offshore British Columbia sonar data [52]. In these datasets, storminess correlated positively with higher emissions due to higher wave hydrostatic pressure variations. Wiggins et al. [51] associated short-term increases with the passage of individual storms (Figure 6).

Interannual data only are available from two COP seep field datasets: repeat (i.e., discontinuous) sonar surveys [40, $102,138,139$ ] and long-term air quality data [53]. Bradley et al. [53] proposed variability on these timescales related to changes in the reservoir overpressure that drives seepage (Figure 3). Specifically, decreasing emissions were correlated with decreasing spatial extent-consistent with the SE model. In the SE model, low resistance migration pathways have higher flux whereas high resistance migration pathways have lower flux and are the first to deactivate when emissions decrease (and reactivate when reservoir overpressure increases). Decadal timescale trends show significant COP seep field area extent changes between 1946 and 1973 [140]. Between 1973 and 1996, the area of seepage around 
Platform Holly decreased, which was ascribed to production reducing reservoir pressure [139].

Temporal and spatial changes are related at large (interannual and kilometer-e.g., Bradley et al. [53]) and small scales (meter and subhourly-e.g., Leifer and Boles [49]). This spatial-temporal relationship arises from connectivity in subsurface migration pathways. On short distances, oil and gas emissions between nearby vents can syncopate, with the oil slug flow forcing gas through the other vent [115].

Where sediments are unconsolidated, emissions are sporadic and highly variable, often transient, with rapidly varying vent location $[36,70,112,114]$. This is distinct from vents associated with migration through fractures in rocks or consolidated sediments. This migration shares similarity to chemical engineering percolation beds [141]. Similar transient behavior was observed in sonar data for the Black Sea [116], Hydrate Ridge [133], and offshore Vancouver Island [52].

1.3.7. Eruptive Emissions. As with many other geologic systems, large and abrupt emissions (eruptions) can occur. Eruptions of, for example, mud volcanoes (terrestrial and marine seeps that emit both $\mathrm{CH}_{4}$ and mud fluids) are well known globally and may be triggered by seismic activity $[142,143]$. Marine seeps often are associated with pockmarks, which are crater-like seabed features, whose formation mechanism remains unclear although it has been proposed that they relate to eruptive events [2].

Given the absence of long-term, seep-monitoring studies, there are few observations of large seep eruptions. Leifer et al. [130] reported on a small eruption for a seep in $20 \mathrm{~m}$ deep water offshore California, which SCUBA diver video showed causing the formation of a bubble with dimensions comparable to the pockmark wall. For a central North Sea seep pockmark, long-term acoustic data recorded a large event that subsequent ROV surveys revealed was associated with a deepening of the crater wall [51]. In Wiggins et al. [51], the acoustic energy time series (which relates to emissions) showed a short cessation followed by a burst that was far stronger than normal, followed by a brief cessation. This was followed by repeat bursts which occurred over the next minutes, eventually establishing a new normal at a higher acoustic level. This same eruptive pattern was observed in the SCUBA diver video, reported in Leifer et al. [130], and for a much smaller event that was observed by a flux tent over a seep in the COP seep field [114]. In the latter event, the eruption increased permeability (cleaned the pipes) leading to higher flow. Leifer et al. [130] proposed these eruptions related to the sudden failure of temporary tar seals of the main migration pathway(s), which were blown free by the eruptive event that also depressurized the migration pathway and near-seabed reservoir. In the absence of oil and tar, selfsealing can occur from carbonate formation [105] or by hydrate formation in the deep sea. A different type of eruptive emission occurs from seismic events that create new migration pathways [144]. This allows formerly trapped, high-pressure gases and fluids to depressurize explosively towards the seabed. Such events can overcome impediments (blockage and constrictions) along the migration pathway.
1.3.8. Seepage and Seismicity. Seep migration often occurs through faults and fractures that penetrate the overlying capping layer, which provide migration pathways. As a result, there is a connection between seismic activity and emissions [145]. Seismic activity can affect migration and ultimately emissions by either breaking existing migration pathways (emission cessation), increasing compressional stress on existing migration pathways (reducing emissions), or decreasing compressional stress and/or the creation of new pathways (increasing emissions). New pathway creation may or may not be eruptive. In the case of new pathway formation, evidence is provided by seafloor features including pockmarks and ridges have been reported to form for a number of different seismic events [145]. In addition, seismic shaking can fracture sealing layers, initiating seepage that can persist for decades [146]. Seismic effects can be extensive. Obzhirov et al. [147] report new seepage stretching $50 \mathrm{~km}$ off Sakhalin Island after an earthquake; Géli et al. [148] report similar extent of new seepage after an earthquake in the Sea of Marmara. Seepage changes also may presage seismic activity [145]. Mechanistically, the buildup of deep fluid pressure can act as a lubricant, allowing the sudden release of seismic energy [149].

Seismicity need not be local to affect geofluid flows. For example, geyser systems have been affected by earthquakes thousands of kilometers distant [137]. Earthquakes can trigger mud volcano eruptions [97] with the distance over which an effect can be detected inversely correlated with strength [150]. Rudolph and Manga [150] found that mud volcano emissions showed greater sensitivity to longer period seismic waves, which they argued was consistent with mobilization of trapped bubbles and sediment grains.

Seismicity also affects overlying marine sediments (that may be gas-charged) by liquefaction, subsidence, and dislocation, as well as sediment failure and translation including submarine landslides [151]. These processes can facilitate gas and oil migration to the seabed. Still, direct linkage of seismicity to seepage can be difficult to establish as most resulting changes occur subsurface, manifesting at the seabed after unknown time lags.

1.4. The Fate of Seep Oil. Marine oil seepage escapes the seabed as oily bubbles or oil droplets, rises, and surfaces within a footprint whose size relates to varying water column currents [7]. On the sea surface, it forms oil slicks that drift from currents and winds and evolve chemically and physically [5]. Slick advection and drift processes are the same for oil from an accidental release as for natural marine oil seepage.

1.4.1. Seabed to Sea-Surface Oil Transport. Seep oil rises slowly as droplets, or far more rapidly as oily bubbles, which have a far greater buoyancy [7]. As oil droplets rise, they lose lighter components (including gases) to the water column through dissolution [60]. Even liquid oil droplets may form bubbles due to effervescence as they rise and hydrostatic pressure decreases [152].

For shallow oil seepage, water column dissolution and current drift are minimal and the oil arrives at the sea surface in a narrow surfacing footprint and forms a slick with similar composition to when it was released. These slicks 


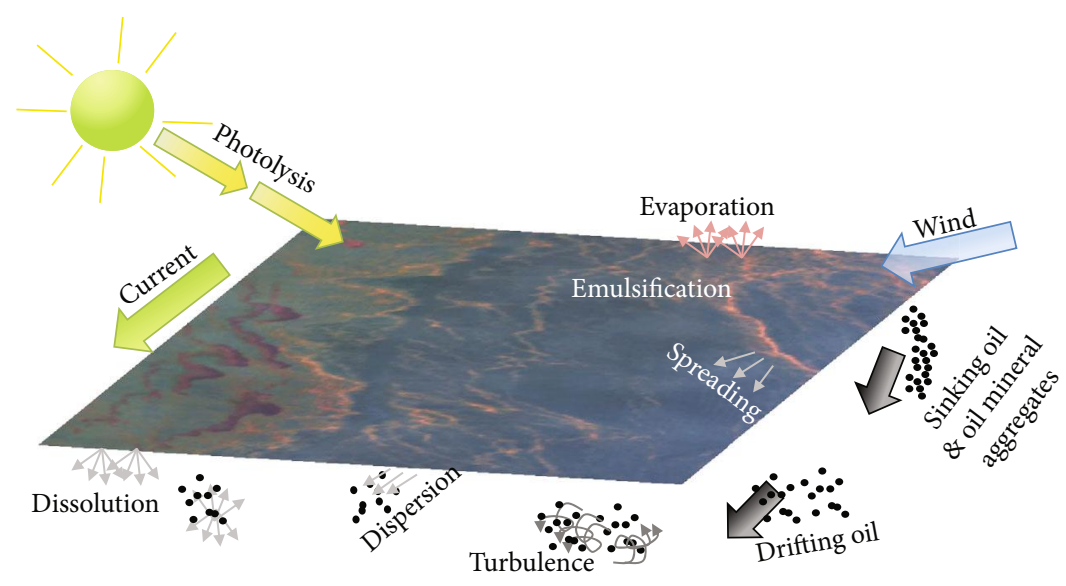

FIgURE 7: Schematic of important early oil slick processes on timescales of up to a few days. Oil image derived from the Airborne Visual Infrared Imaging Spectrometer of the Deepwater Horizon oil spill. Wind and current directions are approximate based on the spatial pattern of the oil slicks. Adapted from Leifer et al. [90].

drift and weather, with the latter transforming the petroleum's chemical and physical properties [5]. Short timescale weathering processes include emulsification, evaporation, and photooxidation (Figure 7) and microbial degradation on longer timescales. As the processes affecting a seep and spill slick are the same, researchers can leverage natural, persistent seepage to understand better oil spill processes [6].

1.4.2. Sea-Surface Transport. Wind and currents drive largescale oil slick movement. Although winds are generally referenced to $10 \mathrm{~m}$ height and currents are measured at a depth of tens of centimeters to meters, the actual interfacial drift velocity lies between the two. Generally, oil is presumed to drift at the vector sum of the currents and wind speed after applying a windage factor of $2-3 \%$ [153], which assumes the interface drifts at the current velocity. Leifer et al. [154] tracked an oil slick in the COP seep field and found that for a $3 \%$ windage factor, there should be a current factor (i.e., not $100 \%)$.

Although several slick processes suggest that oil slicks should disperse [5], oceanographic processes tend to aggregate slicks including Langmuir cells [153], current convergence zones and current shear zones, which can arise from bathymetric effects [90] and other processes, and coherent large-scale turbulence eddies [155]. Typical wind-driven oil slicks are asymmetric [90] due to gravitational and surface tension spreading $[156,157]$, which tend to oppose wind drift in the upwind direction. Additionally, wind momentum is transferred to the slick's leading edge, which abuts oil-free water (mobile interface), more effectively than over the slick, where the interface is immobile. This causes the slick to "bunch up," a tendency that spreading opposes [90].

1.4.3. Evaporation, Dissolution, Emulsification, and Photooxidation. Evaporation causes the slick to lose its lighter components, with faster loss of lighter components [158], leading to a progressive increase in the slick's molecular weight, viscosity, and density $[5,6]$. This process is slower for thicker slicks because the components must diffuse within the oil to the air interface, particularly if the upper surface develops a waxy crust and/or if the oil becomes emulsified [159]. The evaporation rate depends strongly on temperature [158]. For a light gulf crude, evaporation can remove $55 \%$ of the slick mass [158]; for heavier crudes and in cold climates, this can be just a few percent.

For surface slicks and for shallow oil seepage, dissolution negligibly affects oil mass, generally much less than $1 \%$, although this varies with oil type and age, i.e., the volatile fraction. In general, dissolution preferentially involves the lightest components, such as the gasoline fraction, which also are the most toxic [5]. Sublethal and lethal impacts occur at very low concentrations. For example, impacts on larval herring from eggs exposed to $0.7 \mathrm{ppb}$ petroleum polycyclic aromatic hydrocarbons (PAHs) have been identified [160] and at $1 \mathrm{ppb}$ for salmon eggs [161]. Sublethal exposure can induce a delayed (to one year) cardio-function response that alters swimming capacity and survival [162].

Dissolution competes with evaporation, which occurs faster and dominates in the loss of soluble compounds for surface slicks and shallow pipeline leaks and seepage. For deep sea emissions, dissolution losses can remove most of the volatiles before the oil surfaces and forms a slick-with decreased evaporation [60].

Emulsification is the process of water incorporation into oil, creating an oil-water mixture. Oil slick emulsions can be $85 \%$ or more water, greatly expanding slick volume [55]. Emulsions readily form in most light crude oil slicks that are thicker than a few tens of micrometers. For example, remote sensing data for Deepwater Horizon showed that most of the floating oil was emulsified [60, 163]. Driving emulsification is energy input from wave breaking, winddriven turbulence, and human activities. Oil-water emulsion mixtures have distinct physical properties from the original oil, including significantly higher viscosity [5]. Emulsions also volatilize more slowly [159]. By incorporating water into the oil, the oil slick's density increases to near that of seawater (less buoyant) making it more amenable to dispersion into the water column. Stable emulsions can persist for long times, with stability related to asphaltene content, whereas unstable 
emulsions rapidly demulsify, with the water separating from the oil, typically in a few hours [166].

Solar photooxidation breaks molecular bonds in oil components, converting larger and less volatile molecules into smaller and more volatile molecules and fragments that may react with other components. This increases evaporation [165-167]. Currently, oil slick models do not consider photooxidation except for its potential to increase toxicity [168]. Photooxidation reduces the aromatic fraction and increases the asphaltene fraction [169], which should enhance stable emulsion formation. Photooxidation preferentially degrades larger PAHs compared to smaller PAHs and more alkylated compounds before their less alkylated congeners [166]. As with processes like evaporation, the importance depends on solar insolation and oil type.

1.4.4. Dispersion, Sinking, and OMAs. Turbulence can break up surface oil slicks into a dispersion of fine oil droplets that remain "suspended" subsurface [170]. With increasing viscosity, droplet size increases and decreases with turbulence energy. Most natural dispersion is from wind-driven wave breaking [171]. During the Braer oil spill [172], winds and breaking waves rapidly dispersed oil droplets to depths where currents transported them to the southeast (wind-driven surface currents were to the northeast).

Submerged droplets drift with currents until resurfacing once winds subside and turbulence decreases; larger droplets first. For example Braer oil resurfaced when winds calmed. Langmuir circulation likely plays a role in dispersing the oil droplets to greater depths than solely from surface wave breaking [153]. One process that can prevent resurfacing is the formation of oil mineral aggregates (OMAs) [171] or aggregates with other marine particles such as marine snow, termed Marine Oil-associated Snow (MOS). MOS is the aggregation of oil with natural organic material including bacteria, phytoplankton, and zooplankton and natural suspended matter such as flocs and detritus [173]. Daly et al. [173] report that marine snow settles at 10 to $85 \mathrm{~m} \mathrm{day}^{-1}$, slower than MOS sinking rates, which are estimated at 68 to $553 \mathrm{~m} \mathrm{day}^{-1}$ based on laboratory studies. The upper sinking rate is for the largest (tens of centimeters) particles.

Additionally, if the oil is negatively buoyant, or becomes negatively buoyant from evaporation or dissolution, it will sink. For very weak currents (less than $\sim 10 \mathrm{~cm} \mathrm{~s}^{-1}$ ), the oil will sink to the seabed, but stronger currents and turbulence can maintain sunken oil in suspension [174].

1.4.5. Biological Degradation. Biodegradation by natural microbial populations is an important mechanism that removes petroleum and other hydrocarbons from the environment on days to week and longer timescales depending on the petroleum compounds and environmental factors [55]. Susceptibility of oil components to microbial degradation in general decreases from linear alkanes to branched alkanes to small aromatics to cyclic alkanes [166, 175]. Some compounds, including high molecular weight PAHs may not biodegrade [176] allowing their use as biomarkers [166], even in prehistoric bitumen [9]. Numerous microbes that utilize PAHs have been identified and prefer aerobic conditions, although microbial PAH degradation in anaerobic environments, typical of seabed sediments, occurs [177]. Factors affecting microbial oil degradation include hydrocarbon availability, temperature, and nutrients [175]. Photooxidation [169] and biosurfactants [175] can increase the oil's bioavailability.

\subsubsection{Nearshore and Beach Processes}

Overview. Because currents must, by continuity, parallel the coast, onshore winds are required to drive oil, both surface and shallowly submerged, towards the beach in the nearshore ocean. During advection through the surf and swash zones, the longshore current adds an alongshore velocity component. Tar that is stranded on the beach weathers and incorporates sand into its matrix. If buried, erosion can expose the tar later, returning the tar to the swash and surf zones. If not buried, it may return to the swash zone with the next high tide. If negatively buoyant, the undertow then transports the tar offshore, veering to alongshore transport at the breaking point (where bars form) or further offshore if carried by rip currents (Figure 8). In the former case, if wave transport is stronger than the mean offshore transport by the undertow, the tar returns to the beach (unless buried in shallow offshore sediments). Storms amplify these processes.

Nearshore: Beach Waves, Currents, and Transport. Absent a sharp change in shoreline orientation (e.g., a point), oil slicks require an onshore wind (generally the daytime sea breeze) to approach the coast from beyond the shoaling zone. The landsea temperature gradient drives the daytime sea breeze, reversing into the weak offshore nocturnal land breeze. The sea breeze is superimposed on larger-scale winds that may advect oil towards onshore or towards offshore. The land breeze opposes shoreward transport; however, nocturnal winds often separate from upper level winds near the sea surface due to stable atmospheric stratification, nearly vanishing at the sea surface [178].

Once oil reaches the shoaling zone, the rising seabed causes waves to become nonlinear (i.e., not deep water waves) with an onshore transport component [179]. By continuity, water transported onshore must induce a near-seabed return flow-the undertow and rip currents. Between the breaking point and the beach lies the surf zone, whereas the swash zone covers where breaking waves advance up and then retreat down the beach (Figure 8).

The undertow transports sediments offshore, across the surf zone, towards the wave breaking point, and beyond, where the seabed flow reverses to weakly onshore [180]. This convergence leads to sand bar formation in low wave-energy conditions [181]. Transport is strongest near the seabed, decreasing rapidly with height [182].

As the beach slope changes due to sediment deposition and erosion, the breaking point shifts. Thus, for high waveenergy conditions, sediment and bars move offshore, whereas for low wave-energy conditions, they move onshore [181]. During storms, transport in the surf zone can reverse to onshore-with onshore coherent wave transport 


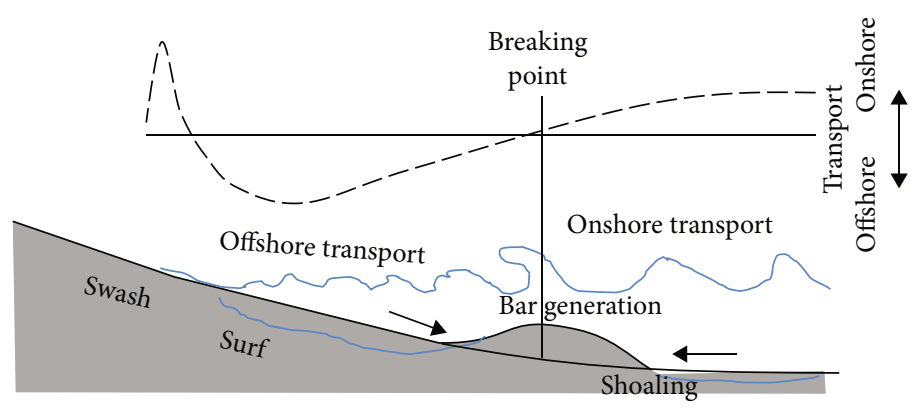

(a)

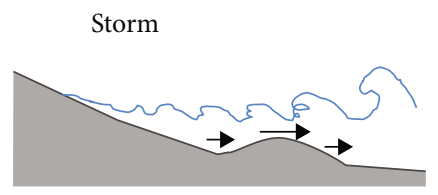

(b)

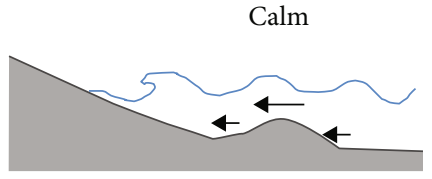

(c)

FIGURE 8: Schematic of nearshore transport. Shape function of velocity moments of the equation for time-averaged sediment transport.

overwhelming the mean offshore transport, i.e., undertow [182]. Swash zone sediment transport is onshore, stranding tar at the highest tide level [178, 183].

Rip currents are high-speed $\left(>0.5 \mathrm{~m} \mathrm{~s}^{-1}\right)$ offshore flows that can be persistent or transient and are driven by uneven alongshore flow. Uneven alongshore flow arises from variations in wave breaking height, seabed bathymetry, wave focusing, and wave shadowing along the coast [184]. Rip currents can rapidly flush out the surf zone, transporting sediment and pollutants including tar (and even bathers), to well beyond the shoaling zone. Currently, the strength of rip currents remains hard to predict, exceeding $1 \mathrm{~m} \mathrm{~s}^{-1}$ during storms [184].

Where waves impact the beach at an angle, the onshore flow has a longshore component, typically $0.3-1 \mathrm{~m} \mathrm{~s}^{-1}$ [178]. By continuity, this longshore component reverses beyond the breaking point [185]. The longshore current's velocity depends on wave angle, wave height, wave period, and beach slope. Simple empirical models, e.g., Harrison [186], and theoretical models, e.g., Longuet-Higgins [187], have been developed for sediment transport application. There also are more sophisticated models based on wave stress that allow for flow convergence in the alongshore direction [188]. Furthermore, field data suggests that winds play a role [185], a process neglected in the Dalyander et al. [188] model.

Although more sophisticated treatments of the longshore current exists, beach parameters are continuously changing, highly complicated, and generally unknown, due in part to sand removal during winter storms and summer buildup. Additionally, adaptation of these sediment transport models to tar is not trivial; tar does not behave as sand. Specifically, direct observations (Leifer, unpublished observation, 2005) suggest that longshore transport occurs beyond the swash zone, though details such as the water depth of transport and where in the swash zone this transport occurs remain unknown. Also, tar is a minor fraction of the beach (sand is the beach) that is nonuniformly distributed on the beach. Specifically, tar strands mostly at the high tide mark [178], returning to the ocean during the next tidal cycle that floods sufficiently high [189]. As a result, beached-tar longshore transport occurs for half a day every day or two.

Stranded Beach Tar. Oil strands at the high tide mark of the flood tide [178] with a size distribution that depends on wave energy and the floating oil's physical characteristics. Wave-breaking turbulence in the surf zone can modify strongly the tar ball size distribution with larger swell leading to more energetic beach wave-breaking that fragments tar balls into smaller sizes. Del Sontro et al. [189] found an inverse correlation between wave height and tar ball size for COP, California.

In the Gulf of Mexico, burial and subsequent reintroduction of beach tar into the surf zone by beach erosion have been documented for stranded Deepwater Horizon tar [188]. On California beaches, buried tar is not found [189]; however, California coastal wave energy is much greater than that for the Gulf Coast. Dalyander et al. [188] found that outside of storms, centimeter-sized tar-sand aggregates were not transported in the Gulf of Mexico. Repeat tar surveys by Del Sontro [190] showed that tar was stranded at the highest swash line by the ebbing tide until the next tide reached the same point on the beach, generally 1-3 days depending on tides. As a result, 
the residence time of beach tar in the Santa Monica Bay, California, was 1-2 tidal cycles [191].

Stranded tar weathers more rapidly than floating oil (same solar insolation) due to warmer beach sand temperatures. Weathering increases the tar's density, as does incorporation of sand into its matrix, rendering it less buoyant. Note that tar buoyancy can increase by incorporation of vegetative material. Upon retrieval from the beach by the flood tide, weathered beach tar is more likely to roll along the seabed or drift and bob above in a sufficiently energetic wave field, than to drift at the sea surface.

\section{Southern California Coastal Seepage}

2.1. Overview. The COP seep field has played an important role in the overall understanding of marine hydrocarbon seepage, due to its significant size and accessibility-an hour by boat from Santa Barbara, CA. COP seep field emissions are the most intense in North America. For comparison, COP emissions are 6-25\% of the estimated Gulf of Mexico oil emissions, arising from just $\sim 13 \mathrm{~km}^{2}$ [40] compared to Gulf of Mexico seepage that covers $11,200 \mathrm{~km}^{2}$ [58], i.e., the COP seep field covers just $0.1 \%$ of the area of Gulf of Mexico seepage. Given its emission strength, impacts from the COP seep field dominate both locally and at significant distances. Impacts are spatially asymmetric, extending further in the direction of coastal currents and prevailing winds.

Seepage occurs along much of the southern and central California coast; thus, as the influence of COP seep field emissions diminishes with distance, the impact from local seepage becomes increasingly important. Still, even in the Santa Monica Bay, $130 \mathrm{~km}$ from the COP seep field, the COP seep field's influence is notable. For example, Hartman and Hammond [191] ascribed 20\% of Santa Monica Bay beach tar balls to the COP seep field.

The ecosystem impacts of seep oil decrease with distance due to dispersion and weathering (which reduce its toxicity). In the case of the COP seep field, it has influenced the local and regional ecosystems for at least 500,000 years [192], i.e., evolutionary timescales. These impacts are positive and negative; seep petroleum is both a bioavailable energy source (chemosynthetic) and an environmental stressor [71].

\subsection{Historical Seepage in the Santa Barbara Channel. Seepage} has influenced regional indigenous people's culture and lives for thousands of years in the Santa Barbara area and elsewhere in California. For example, the Chumash Indians of the Santa Barbara region used tar for waterproofing canoes [193], bottles and utensils, and in clothing and jewelry [19]. Asphaltum-waterproofed bottles have been identified on the San Nicholas Islands dating from 4450 to 4850 years ago [194]. Sources included mainland seeps but also floating tar from marine seepage, which was used by the Island Chumash [195]. Terrestrial tar was considered higher quality and sourced from seepage in the Santa Barbara and Ventura Counties and the South San Joaquin Valley and also Los Angeles [196], which includes the La Brea Tar Pits. The tar pits have been active for at least a million years [19] and are a well-known, modern tourist attraction. As in the Middle
East, asphaltum's value spawned an active trade in its liquid form (transported in baskets) and as hand-molded pads, formed after heating [198]. Tar trade routes were extensive; the Yokuts Indians in the San Joaquin Valley collected tar from oil seeps, which was traded as far as the Mojave Desert [197].

2.3. Spatial Distribution of Seepage. Geologic basins with gas and oil fields are found along the entire coastal length of California, in the Transverse Mountain Range, and in the San Joaquin Valley (Figure 9). In California, at least 52 gas and oil fields were discovered after drilling near seepage [19], highlighting the close relationship between oil basins and seepage. Some of these reservoirs are in geologic basins that extend from onshore (where oil production is located) to offshore, indicating the potential for offshore oil and gas seepage [198]. Seepage requires both hydrocarbon accumulation in a reservoir formation (a trap) and a migration pathway to the seabed or atmosphere for terrestrial seepage. In most of California, the Miocene-age Monterey Formation is the main hydrocarbon formation, serving as both the source reservoir and formation reservoir [199]. Examples include the Monterey Formation hydrocarbon reservoirs in the coastal Ventura, Santa Barbara, and Santa Maria Basins [200], and the interior San Joaquin Basin [199].

The presence of a trap is critical. Much of the onshore Santa Barbara Basin has no trap potential and thus no potential for accumulation and associated seepage [200]. One mechanism for trap formation is tectonic, which manifests as faults and folds [106]. Faults, in addition to creating hydrocarbon accumulation traps, also can provide migration pathways for seepage $[100,102]$. Examples include the faults and folds along the northern Santa Barbara Channel [201] and the San Andreas Fault on the western edge of the San Joaquin Valley [202]. Faults also fracture the overlying capping layer, providing migration pathways through the overlying rock layers and sediments to the seabed [102] as do slump scarps [201].

There is active hydrocarbon formation in these basins. In the COP area, active formation occurs in the Monterey Formation deeper than $\sim 3$ to $4 \mathrm{~km}[203,204]$ and deeper than $2 \mathrm{~km}$ near Point Conception [200]. The Monterey Formation is a fractured reservoir with high porosity (10-30\%). Although its permeability is low (30\%), fractures provide highly permeable migration pathways [205]. This permeability leads to strong vertical geothermal gradients of $25-50^{\circ} \mathrm{C} \mathrm{km}^{-1}$ in the Santa Barbara Channel and Santa Maria fields.

California offshore marine seepage is widespread and has been documented in the Ventura-Santa Barbara Basin, with seepage near Point Conception, COP, and Rincon Point, and in the Los Angeles Basin, with seepage in the Santa Monica Bay and offshore Long Beach (Figure 10). Additional isolated areas of seepage have been reported near several Channel Islands. More recently, Lorenson et al. [125] identified seepage offshore of Santa Maria (northwest of Point Conception), in the Monterey Bay and in Half Moon Bay, and offshore in several Northern California offshore basins (Figure 9).

The COP seep field is arguably the best-studied offshore seepage and among the largest in the world [40]. The COP 


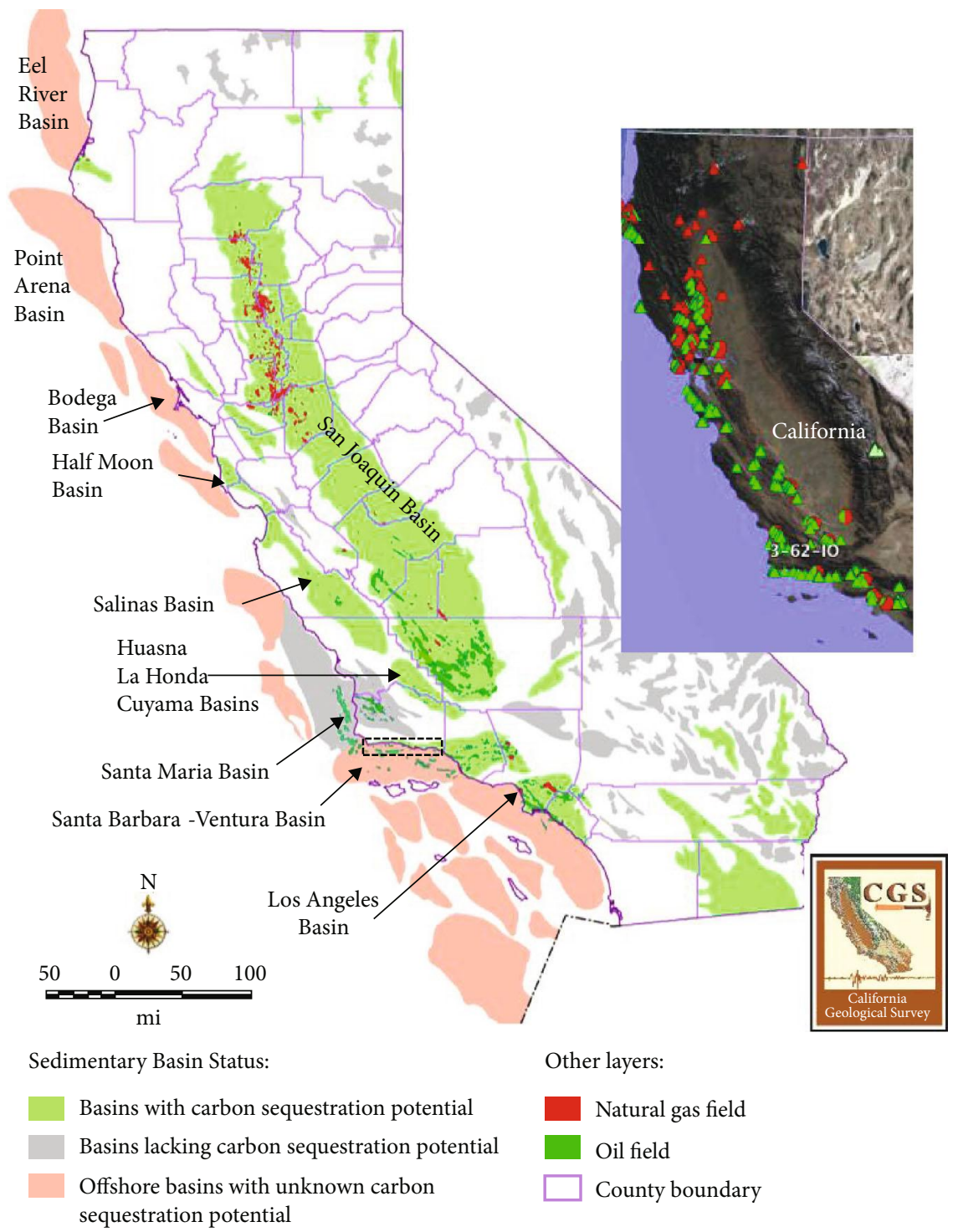

FIgURE 9: California Geologic Basins with oil potential and oil and gas fields. Adapted from WESTCARB [258]. Box shows location of north Santa Barbara Channel geologic transect in Figure 11. Inset: known seepage locations. Original data from Lorenson et al. [125] displayed in Google Earth. Note that this map neglects seeps located in active production fields, but which predates the field.

seep field sources from an offshore extension of the Ellwood oil field, which extends from beneath Goleta, CA. The offshore extension's structure is complex due to faulting and folding [206]. Seepage also occurs offshore Ventura. This seepage sources from the offshore extension of the reservoir that underlies onshore natural seepage in the upper Ojai Valley area [207] along the Santa Clara River and Santa Paula River [208] and other nearby areas such as the Carpentaria bluffs and beaches [198].

Important seepage also occurs to the west of the COP seep field, in waters offshore Point Conception, where asphalt mounds to $18 \mathrm{~m}$ tall cover an estimated $5.4 \mathrm{~km}^{2}$ of seafloor. These seep fields also emit oil and gas [209-211].

Seepage is widespread in the Los Angeles Basin, including the oil and gas seepage of the La Brea Tar Pits [19]. The tar pits are a significant source of both $\mathrm{CH}_{4}$ and nonmethane hydrocarbons (NMHC) to the Los Angeles Basin. Weber et al. [212] estimated La Brea Tar Pits' $\mathrm{CH}_{4}$ emissions of $0.9 \mathrm{Mg} \mathrm{yr}^{-1}$ from 100 active seeps located in the park; Etiope et al. [213] estimated $0.3-0.6 \mathrm{Gg} \mathrm{yr}^{-1}$ from the park proper. These values are a small fraction of the $61 \mathrm{Gg} \mathrm{CH}_{4} \mathrm{yr}^{-1}$ emissions from the tar pits and associated nearby geologic formation estimated by Farrell et al. [214], suggesting that geological emissions outside of the park contribute significantly. For comparison, Hsu et al. [215], in a bottom-up estimate, suggests the Los Angeles County $\mathrm{CH}_{4}$ budget is $200 \mathrm{Gg} \mathrm{yr}^{-1}$, whereas Peischl et al. [216] in a top-down estimate suggests around $400 \mathrm{Gg} \mathrm{yr}^{-1}$, and Wennberg et al. [217] found $440 \mathrm{Gg} \mathrm{yr}^{-1}$, also from a top-down estimate. Peischl et al. [216] suggested that the difference with Hsu et al. [215] is from natural seepage and/or pipeline leakage. It is notable that the La Brea Tar Pits are only one of several geologic seep areas in the basin. Natural seepage occurs along the Palos Verde Fault extending offshore around Redondo Beach 

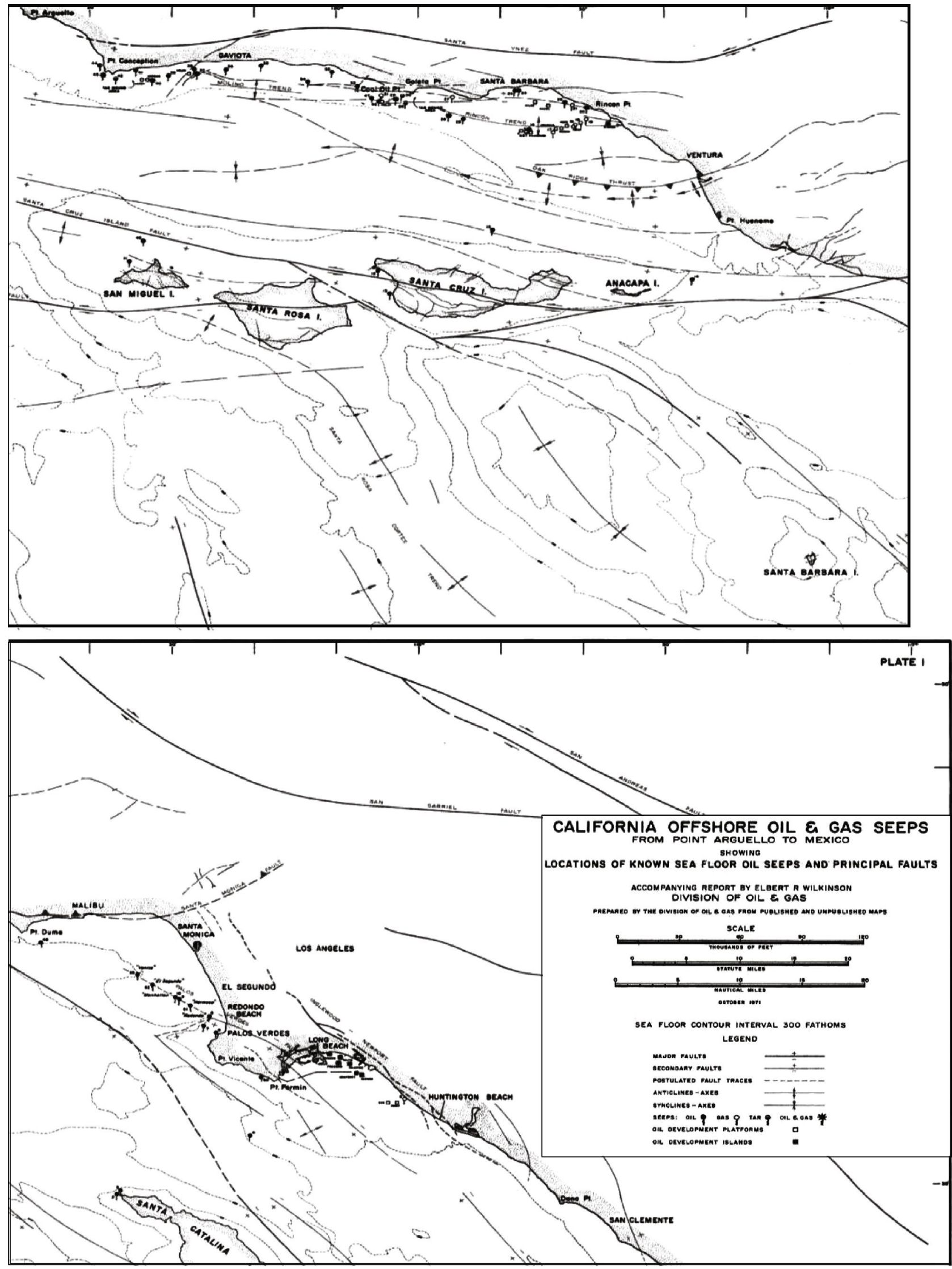

FIGURE 10: Southern California offshore seepage and major faults. Arrows show fault direction. From Wilkinson [198]. 


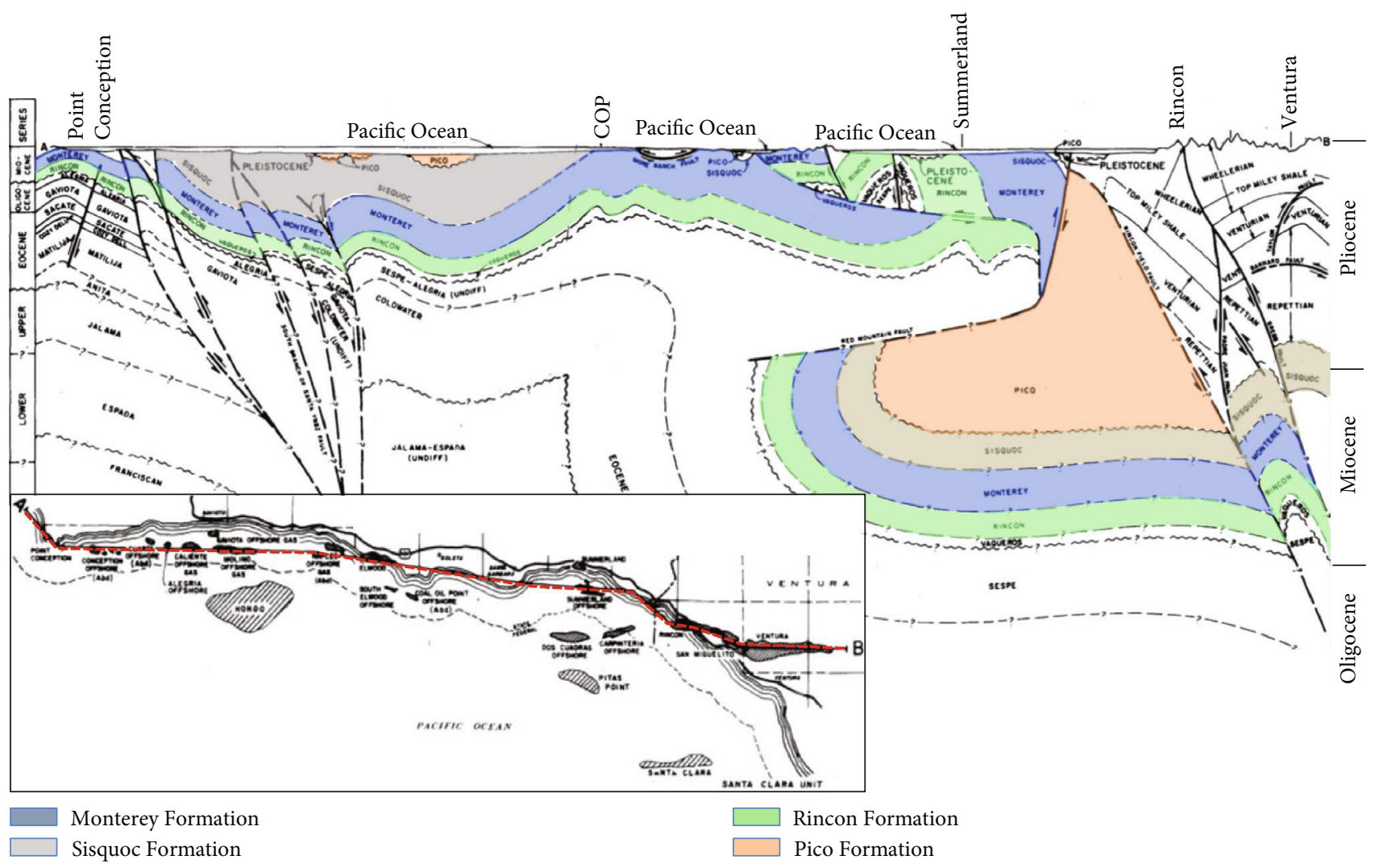

Figure 11: Generalized northern Santa Barbara Channel geological cross section from Point Conception to Ventura. Adapted from CDOG [259].

and Manhattan Beach and into the Santa Monica Bay [198]. Thus, geologic emissions could play an important role in the discrepancy between the bottom-up and top-down estimates. Using the $\mathrm{CH}_{4}$ to NMHC $\left(\mathrm{C}_{2}-\mathrm{C}_{5}\right.$ : ethane-pentane) ratio measured for La Brea seep gas and the Farrell et al. [214] $\mathrm{CH}_{4}$ emission estimate, Weber et al. [212] estimated La Brea Tar Pits' NMHC emissions of $1.7 \mathrm{Gg} \mathrm{yr}^{-1}$ or $2-3 \%$ of the total Los Angeles Basin's light alkane emissions.

2.3.1. COP Seep Field Geology. The COP seep field is by far the largest and most intense marine California seep field with respect to gas emissions and its oil emissions are the largest or second largest in California with the other largest oil seepage from seep fields near Point Conception [40, 125]. Most COP seep field seepage arises from reservoir traps at $\sim 1 \mathrm{~km}$ depth [102]. A key factor is the capping Pliocene-age Sisquoc Formation, which overlays the Monterey Formation, allowing hydrocarbon accumulation [204]. Gradual folding created a major anticlinal trap where hydrocarbons accumulate while also fracturing the overlying Sisquoc Formation along and parallel to a major fault. Fractures and faults above the anticline are noncompressional, allowing hydrocarbon migration to the seabed. In contrast, nearby compressional faults and fractures block migration and hence seepage [102].

The geologic setting is critical - the strongest marine seepage in the Santa Barbara-Ventura Basin occurs where the Monterey Formation crests-around Point Conception and offshore Goleta (i.e., the COP seep field, where portions of the formation outcrops). The Monterey Formation also outcrops offshore Summerland, but folds isolate the shallow reservoir that drives Summerland offshore seepage from the deeper Monterey Formation (Figure 11). As a result, Summerland wells went dry after a few decades of production in the early 1900s [94].

Leifer et al. [102] presented a structural geologic model (Figure 12) for the COP seep field that adds to the overall details in the northern channel structural model (Figure 11). The model shows good spatial correlation between crests of the Monterey Formation, faults, and location of the strongest seepage and its absence. The relationship between seep location and the structural model shows that migration is three dimensional-both updip towards the "ridge" of the Monterey Formation parallel to the coast and along the ridge (along-coast) towards local crests [102]. Intersecting faults are important as they create brecciated rock chimneys with numerous migration pathways and thus are resistant to permanent tar sealing.

The strongest seepage occurs close to above the anticline crest, slightly offset to the south due to the dip of the S. Ellwood Fault-more properly the S. Ellwood Fault System (SEFS) with several parallel faults mapped. A thick damage zone is associated with the SEFS. Additional seepage is found inshore of the Red Mountain Fault. In contrast, minimal seepage is found from where the Monterey Formation outcrops at the seabed. In part, this is from near-surface biodegradation that forms tar seals that block hydrocarbon migration [99] and also because an outcropping does not 


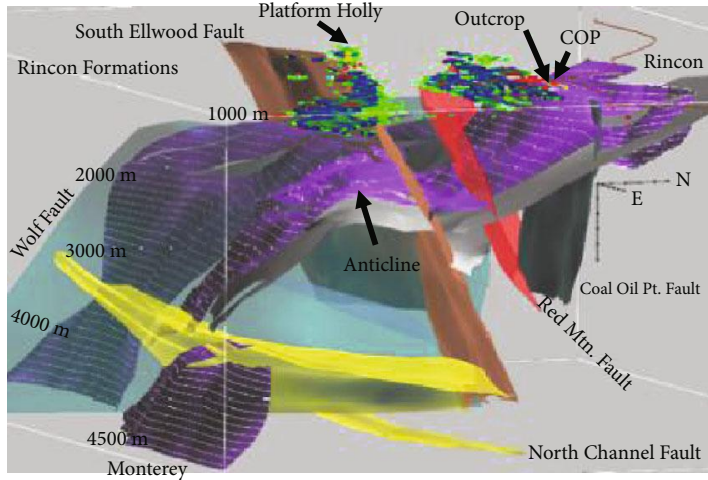

(a)

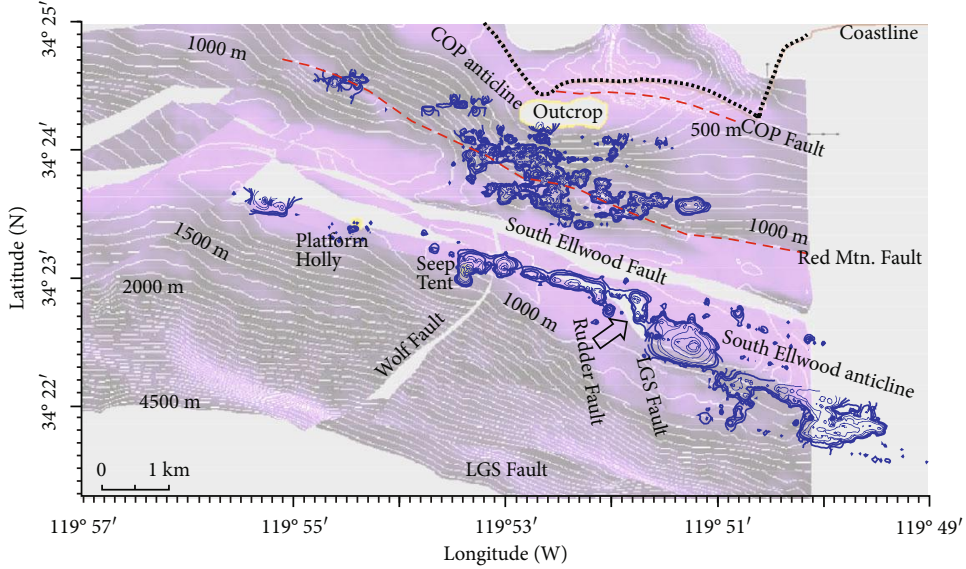

(b)

Figure 12: Coal Oil Point (COP) seep field sonar map (red: strong emission, blue: weak) and underlying geologic structure: (a) oblique view from above looking northwest; (b) overhead view of Monterey and Rincon Formations and faults labeled. The Monterey Formation outcropping is a sea surface projection. Projection is uniform with orientation axis with size scale dots on the axis every $200 \mathrm{~m}$; contours are $100 \mathrm{~m}$. Figure by Mark Kamerling, Venoco Inc.

allow hydrocarbon accumulation. Also contributing is that because hydrocarbon migration occurs most strongly along the nonconformity with the overlying Sisquoc Formation, seepage outlines the outcropping, primarily to the south and west-updip migration [102]. Thus, seepage at the outcropping's edge is in the direction of the faults that define Coal Oil Point, where seepage extends the closest towards shore and shallowest-into the swash zone at depths of a few meters. Also contributing to the weakness of seepage around the outcropping is that updip migration along bedding planes towards the outcropping loses hydrocarbons to the seabed through fractures parallel to the Red Mountain Fault during its migration. Some of these vertical migration pathways are associated with strong seepage [102], with their emissions reducing the amount of seepage that eventually reaches the seabed along the nonconformity. The geologic model is discussed in greater detail in Section 2.4.6, in regard to seep surveys spanning 60 years.

\subsubsection{Point Conception and Summerland Seepage Geology.} South of Point Conception, seepage is noted over two trends, the Conception seep field and the Cojo seep field, which follow the major offshore anticline and associated faults that allow hydrocarbons to accumulate (Figure 13). These seep trends span almost $9 \mathrm{~km}$, significantly more extensive than the COP seep field trends (Figure 12). Underlying this greater extent likely is the intersection of the north-south trending faults with the east-west trending faults that define Point Conception. This more complicated fault zone could create more extensive traps than in the comparatively simpler geologic setting of the COP seep field.

More recently, north-south trending seepage in the offshore extension of the Santa Monica Basin (Figure 9) was mapped by Lorenson et al. [125] to the west and northwest of Point Conception. Driving this seepage is the Monterey Formation's shallowness, which includes outcropping (Figure 11). Beneath the Monterey Formation lies the Pliocene-age Pico Formation, which also is a hydrocarbon reservoir, with formations identified in the Santa Maria Basin [218]. Based on the onshore Santa Maria Basin location of oil production, such as the Guadalupe Field to the west of Santa Maria near the coast, offshore seepage almost certainly extends further north along the central California coast than has been mapped, e.g., Lorenson et al. [125].

Point Conception seepage includes gas, oil, and tar, with observations of tar whips escaping from tar mounds (see Figure 5(e)). Many seeps are pure oil, unlike in the COP seep field where oil is almost always accompanied by gas. These tar seeps lead to tar balls on beaches around Point Conception that are far larger than tar balls near COP [125].

Fischer [50] argues that the low gas to oil ratio relates to these seep field's maturity; however, the underlying mechanism likely is more complicated. One possibility is that migration from the deeper Monterey Formation is impeded in part by nonconformities due to branches of the northsouth Santa Ynez Fault (Figure 12), which includes the Gaviota Fault. Sporadic seepage has been identified between the Point Conception seep fields and the COP seep fields, generally along the same anticline [50]. Underlying this seepage sparseness is the far greater depth of the Monterey Formation for these seep fields (Figure 11). Still, most details of the relationship between geology and seepage for the Conception and Cojo seep fields remain uncharacterized.

The Monterey Formation outcrops in Summerland, $\sim 40 \mathrm{~km}$ east of the COP seep field, which was the site of the first offshore US oil well [95]. Numerous wells were drilled from piers extending offshore, providing fine-scale detail on near-surface geology [94]. Oil has accumulated in overlying formations, such as the Casitas Formation. Seepage arises from a nearshore anticline associated with the Summerland Fault [219]. In a more recent study, Leifer and Wilson [115] mapped an offshore seep trend of oil and gas that aligned with the onshore Ortega Fault, which transects Ortega Hill, the site of a well drilled in 1886 [220]. Some of the abandoned oil wells offshore Summerland continue to leak [127]. Summerland seepage is minor compared to the COP seep field 

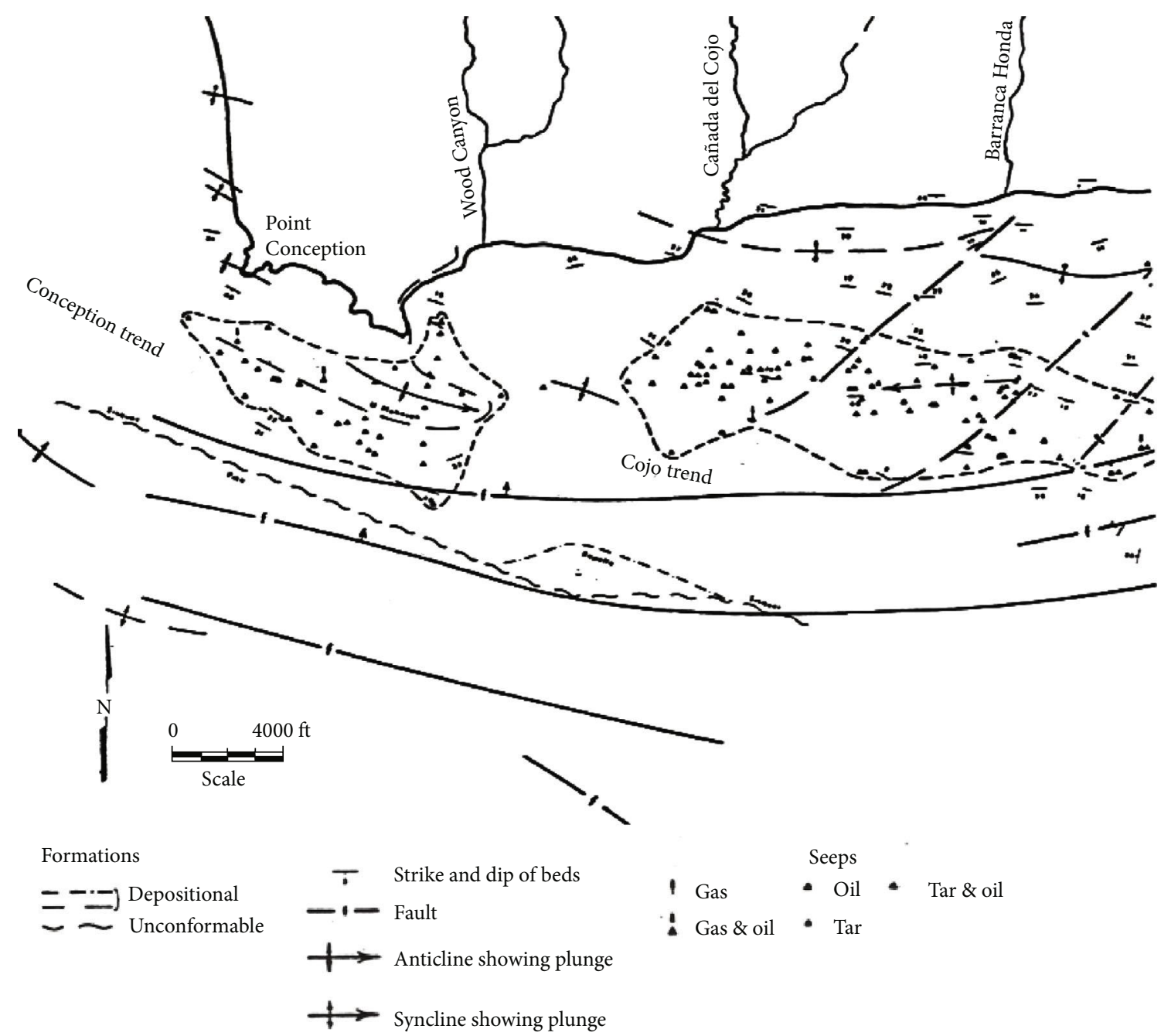

Figure 13: Geology and gas and oil seepage off Point Conception. Legend on the figure. Adapted from Fischer ([50], Fig. 5).

due to disconnection of its shallow reservoir from the deeper Monterey Formation source (Figure 11).

\subsubsection{Santa Monica Bay: Redondo Beach Seepage. Seepage} has been documented for a number of locations in the Santa Monica Bay extending along the Newport-Inglewood Fault into deeper water and across to offshore of Point Dumé (Figure 10). The Long Beach and Seal Beach oil fields lie to the east of San Pedro Bay and Redondo Beach [221], an area of reported marine seepage [125]. Oil is produced from structural traps formed by fault deformation in the NewportInglewood Fault Zone. The reservoir formation is the upper-Miocene Puente Formation and the lower-Pliocene Repetto Formation at depths of $\sim 1,400 \mathrm{~m}$ [221].

2.3.4. Channel Islands Seepage. The Monterey Formation, which is the source of seepage on the northern rim of the Santa Barbara Chanel where it rises near the coast, also rises on the southern rim of the Santa Barbara Channel around the Channel Islands. Fischer [50] reports marine seeps in the southern Santa Barbara Channel (Figure 14), several of which lie along the Santa Cruz Fault and its branches. Tar balls that were found on Santa Cruz Island were assessed as having derived largely (65\%) from offshore seepage near the island's western end [222].

2.3.5. Riverine Seepage. Terrestrial seepage in coastal hills and mountains potentially can enter streams and rivers and ultimately the ocean. Distance to flowing water is important; thus, seepage near or in streambeds and riverbeds is far more likely to contribute to riverine oil fluxes. Oil readily forms oil mineral aggregates in energetic, shallow rivers and can be buried in river/streambed sediments or permanently attaches to debris and vegetation; thus, distance to the coast also is important. For example, seepage in the Amazon River mouth [56] is certain to reach the ocean, whereas oil seepage in the San Joaquin Valley, Central California, that reaches nearby streams is far more likely to deposit in the riverbed/streambed rather than reach the distant ocean. Finally, higher fluvial flow allows oil to bypass catchment pools with decreased losses to sediments and vegetation [208]. Thus, increased river flows from storms increase the inland distance that riverine flows can transport oil to the ocean.

Where geologic basins extend from onshore to offshore, there is increased potential for riverine seep oil inputs to the ocean. For example, Leifer and Wilson [208] 


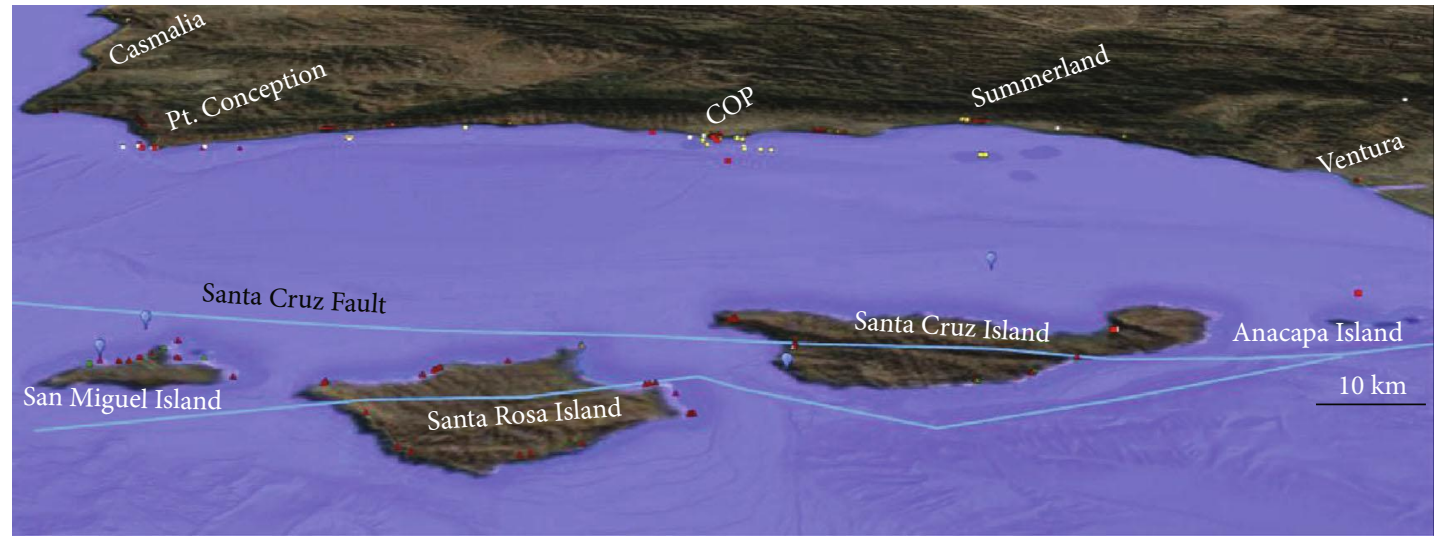

$\begin{array}{ll}\nabla \text { Source rock } 0 & \square \text { Seep } 0 \\ \oplus \text { Production oil 0 } & \square \text { Seep 1 } \\ \oplus \text { Production oil 1 } & \square \text { Seep 2 } \\ \oplus \text { Production oil 2 } & \square \text { Seep 3 }\end{array}$
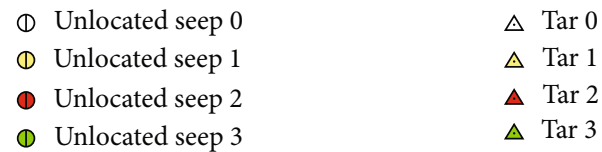

FIGURE 14: Visualization of major faults and location of seeps around the Channel Islands. Based on data in Fischer [50] and tar ball sample location from Lorenson et al. [125]. See data key for tar sample "tribes" or chemical grouping. Displayed in the Google Earth environment.

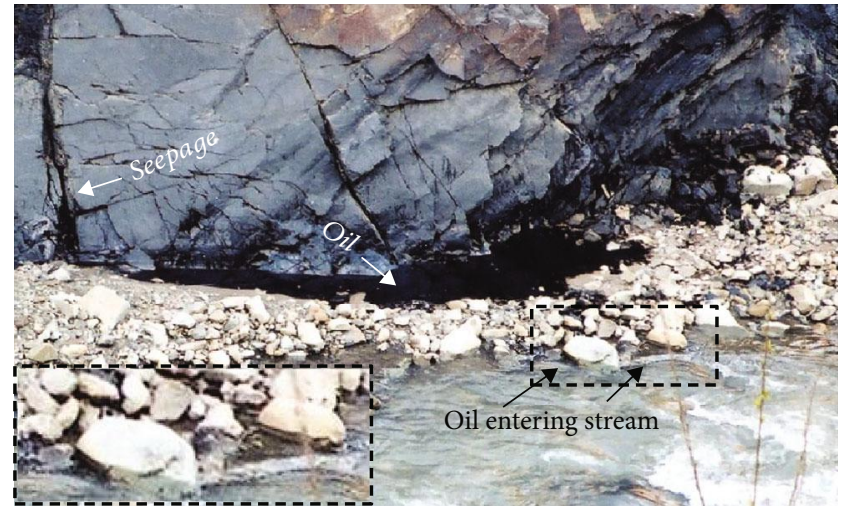

FIgure 15: Photo of oil accumulation in the Santa Paula River from riverbank seepage. Tar is visible in fractures in the exposed rock matrix. Inset shows an enlarged area where oil enters the water and flows downstream. Photo: Ken Wilson and Ira Leifer.

documented seepage in the riverbed and riverbanks of the Santa Paula River that accumulated in pools (Figure 15) and on vegetation. Leifer and Wilson [208] documented that these pools overflowed for elevated rain (storms) with the oil reaching the $35 \mathrm{~km}$ distant Pacific Ocean-causing the Ventura Oiled Bird Incident (VOBI). The VOBI extensively oiled marine birds from Santa Barbara to the Santa Monica Bay with the distribution of VOBI-oiled birds clustered around the Santa Clara River mouth, through which Santa Paula River water outflows to the Pacific [223].

For oil seepage near a river, downslope flow is very slow and decreases as the oil weathers, leading to the tar flow freezing in structures resembling lava flows, preventing them from reaching flowing water [207, 208]. Tar flow (oozing) is temperature-sensitive; thus, tar flows further in summer. Still, the tar from Ojai area seepage studied by Duffy et al. [207] showed no indication of reaching flowing water, even in summer. Additional riverine input occurs when oil in sediments associated with terrestrial seepage erodes into flowing water, either from erosion under normal fluvial flows or from enhanced erosion during high flow periods. The latter was identified as a contributing factor to Santa Paula River oil transport to the Pacific Ocean [208].

Riverbed catchment structures (natural from fallen vegetation, and rocks, or engineered) play a dualistic role-preventing downstream oil transport while enabling accumulation of floating oil in pools (Figure 15) that then weathers. However, when the river rises and overflows the catchment structures, accumulated oil can be released in a large pulse that is likely to travel further downstream than a slow trickle of similar total volume. Higher river flows also reduce vegetation contact, by either sweeping away vegetation or by submerging it, reducing oil interaction and potential adhesion to the vegetative matter during downstream transport. Additionally, oil that may have been buried in riverbed and riverbank sediments can be released into the flow by erosion. Oil from river bank sediments in the Santa Paula River was a contributing factor to the VOBI [223].

Despite the well-documented widespread occurrence of terrestrial seepage in several coastal petroleum basins [125], there is virtually no literature on river transport of natural seep oil in California or elsewhere, its inputs to the ocean, its impacts, and fates. This knowledge gap is significant and important, given the magnitude of VOBI as documented by Leifer and Wilson [223] for the Santa Barbara-Ventura Basin. Similar riverine impacts could occur for the Los Angeles, Eel River, and Santa Maria Basins.

\subsection{Temporal Variability of Seepage}

2.4.1. Overview. Natural hydrocarbon seepage varies on timescales from second to decadal both for continuous emissions and for episodic emissions. Additionally, continuous emission systems can episodically erupt. Finally, temporal and spatial emission variability often is interconnected with emissions shifting between connected subsurface migration pathways. 
2.4.2. Waves and Hydrostatic Pressure. Hydrostatic pressure variation affects emissions on timescales as short as those of ocean swell-first documented in the COP seep field $[49,70]$, where typical swell is $\sim 10 \mathrm{~s}$. Stronger seepage was observed to be modulated, whereas weaker seepage was observed to be episodic and correlated with swell [70]. This is consistent with the resistance model (Figure 3) where higher resistance migration pathways have lower flux and thus are the first to deactivate when the driving force (hydrostatic pressure) increases. These deactivated vents also are the first to reactivate when pressure decreases $[115,131]$. Thus, the resistance model implies that tidal emissions activate and deactivate seepage on both tidal and swell timescales. Leifer and Boles [49] measured seabed emissions with a turbine tent that isolated seepage from swell surge so that modulation was purely from well hydrostatic forcing.

Isolation from surge is important in this type of measurement as Leifer and Boles [114] showed a clear correlation between flux and surge velocity from swell at $60 \mathrm{~m}$ deep seepage in the COP seep field from video bubble measurement data. These surge observations agreed with lab studies that show that cross flow lessens the energy of bubble formation [224], enhancing seepage. Thus, both seabed surge flows and hydrostatic pressure play a role in wave forcing.

Seasonal variations in emissions have been identified in decadal-long COP seep field air quality data [53]. Seasonal variations in emissions also have been identified in other datasets, e.g., Römer et al. [52] for $1250 \mathrm{~m}$ deep water and Wiggins et al. [51] for $100 \mathrm{~m}$ deep water, with higher emissions and higher variability correlated with storms. In coastal waters, storms are associated with increased wave height and surge at the seabed, which can move sediment that may obstruct a seep vent. Although in deep water $(1,250 \mathrm{~m})$ offshore British Columbia, hydrostatic pressure fluctuations are very small and there is no surge, a clear signature from storminess was observed [52]. These data suggest that hydrostatic pressure is the dominant mechanism affecting seepage from swell to synoptic timescales.

2.4.3. Mechanism of Hydrostatic Pressure Change and Seepage. The reaction of seepage to very small pressure fluctuations at 1,250 m suggests extreme pressure sensitivity with emissions finely balanced between near-seabed reservoir recharge from below and discharge to the seabed. This drives a highly nonlinear response of seepage to changes in seabed hydrostatic pressure, with sensitivity inversely related to flux [49].

Interplay between gas vents (Figure 4) was documented for Shane Seep in the COP seep field by Leifer and Boles [114] and between oil and gas emissions in Leifer and Wilson [115] for a two-vent seep system for a leaking, abandoned oil well offshore Summerland. Oil emissions were observed to be slug flow, with oil blocking gas emissions from one vent, driving increased gas emissions from the other vent. As the oil slug cleared and gas flow resumed from the first vent, the second vent's emissions decreased as more of the flow began passing through the now more open, first vent. This interplay depends on pressure buildup and discharge from the near-seabed reservoir.
2.4.4. Eruptive Emissions. Whereas hydrostatic pressure affects the driving pressure at the seabed, geological processes can affect the driving pressure on the reservoir side by altering the reservoir pressure through increases or decreases in recharge and by alterations in the migration pathway resistance(s), including opening or activation of new migration pathways and narrowing through deposition or destruction of existing migration pathways. Geologicaldriven changes can be slow and evolutionary, or they can be abrupt, producing large transient (eruptive) emissions.

Few quantitative observations are available for eruptive emissions for the COP seep field or elsewhere. As a result, the eruptive contribution to overall annualized emissions remains uncharacterized.

The only detailed, quantitative observation of a seep eruption is from a turbine seep-tent network deployed in $20 \mathrm{~m}$ water at Shane Seep in the COP seep field, which recorded seep fluxes at $1 \mathrm{~Hz}$ [114]. The time series (Figure 16) showed a trend with similar characteristics to qualitative observations in the SCUBA diver video for Shane Seep reported in Leifer et al. [130], during a different campaign, and in acoustic, semiquantitative observations for a seep eruption in the North Sea [51].

Based on these observations, Leifer et al. [130] proposed that these types of eruptions relate to a temporary seal of the main migration pathways, which then blows free during an eruptive event that also decompresses the migration pathway leading to a cessation of flow. During the temporary seal, seepage in other migration pathways backflows from the now sealed (deeper) migration pathway. The eruption observed in Leifer and Boles [114] lasted $\sim 5$ seconds and comprised $\sim 6$ bursts (Figure 16(b)).

Eruptive events can affect migration path permeability by freeing (eroding) and transporting sediment, tar, and other unconsolidated blocking materials on timescales that are much longer than the eruptive event (Figure 16(a)). This increased flow slowly depressurizes the deeper reservoirs that feed the shallower reservoir leading to a gradual decrease in post-eruption emissions. Eventually, tar and other sediments begin to reconstrict migration pathways, trending emissions towards pre-eruption conditions. Thus, the overall impact from eruptive emissions arises not from the (short-lived) eruption but from the relatively long-term increase in overall emissions during the "adjustment" period.

2.4.5. Seasonal Variability. Seasonal variations in COP seep field emissions were identified in long-term atmospheric total hydrocarbon (THC) data from West Campus Station (WCS), located near Coal Oil Point and the COP seep field. Specifically, winter THC concentrations are higher than in the summer (Figure 17). Since summer winds are weaker, this implies that THC seasonality at WCS underestimates the magnitude of seasonality in field emissions (dilution is more in winter than in summer).

Seasonal storms likely play an important role in seep emission seasonality. Potential storm forcing mechanisms could relate to hydrostatic pressure, seabed scouring, and aquifer recharge. Aquifer recharge causes increased reservoir pressure from seasonal rains. For both offshore British 


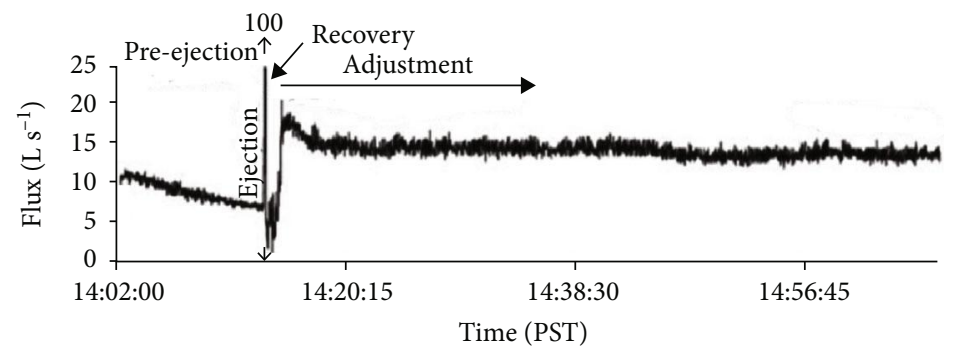

(a)

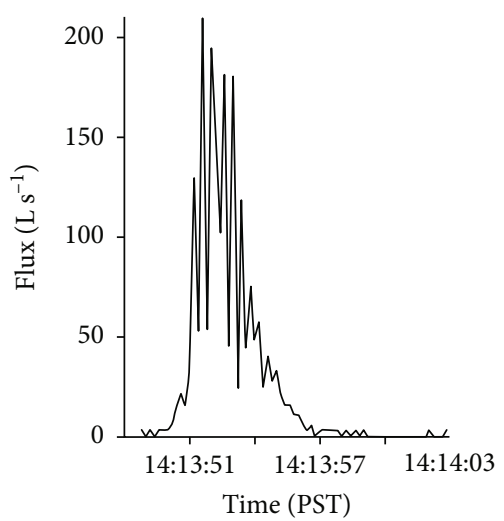

(b)

Figure 16: (a) Emission time series of a seep eruption at Shane Seep (20 m) in the Coal Oil Point seep field. (b) Detailed time series of the eruption. Adapted from Leifer and Boles [114].

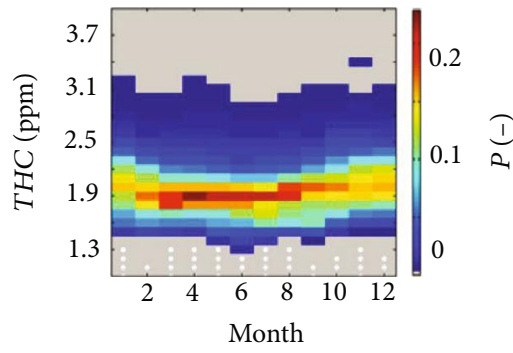

(a)

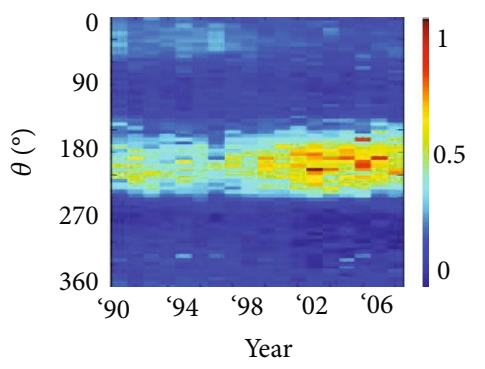

(c)

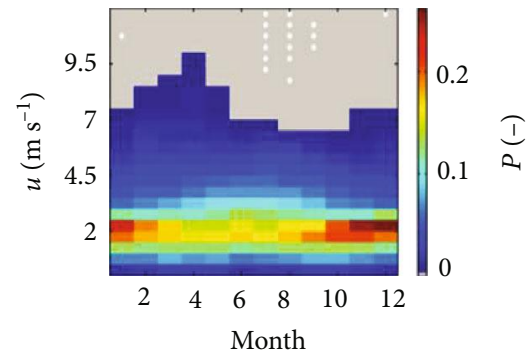

(b)

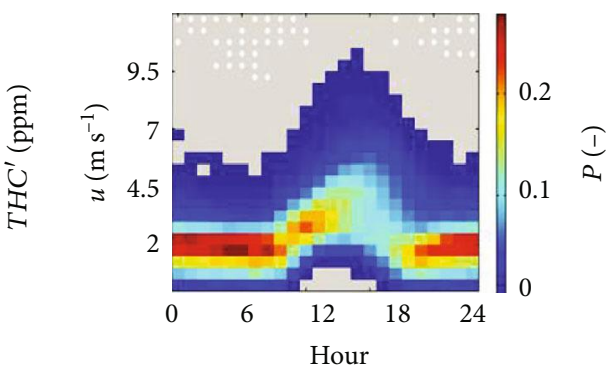

(d)

FiguRE 17: Normalized probability histogram $(P)$ of (a) monthly averaged total hydrocarbon $(T H C)$ concentration for West Campus Station for 1991-2009 for (b) wind speed $(u)$ showing seasonal trends. (c) THC anomaly (THC) relative to non-seep directions versus wind direction $(\theta)$, and (d) $P$ of $u$ relative to hour showing diurnal trend. From Bradley et al. ([53], Figs. 4 and 6).

Columbia [52] and the North Sea [51], seepage is too deep and/or too distant from shore for aquifer recharge or seabed scouring to be responsible. The first process, wave hydrostatic pumping, has been demonstrated for non-storm waves [49] and should be significantly greater for storm swell. Given the close correlation between oil and gas seepage, which use the same migration pathways, increased oil emissions also are likely during the stormy season.

2.4.6. Interannual Trends. Interannual to decadal datasets are only available for the COP seep field. Data include repeat (i.e., noncontinuous) sonar surveys $[40,41,50,102,139]$ and continuous air quality data [53].

Decadal trends are evident in areal extent changes from 1946 to 2005 (Figure 18) in maps for the mid-1940s and early 1970s from Fischer [50], mid-1990s from Hornafius et al. [40], and mid-2000s from Leifer et al. [102]. Comparison between surveys had to consider deficiencies from differing equipment, areas surveyed, and reporting.

New data outlines were drawn for the 1940s data, ignoring oil reports, because oil droplets can drift significant distances before surfacing. Specifically, the map shows oil seepage (but not gas seepage) between the Ellwood and COP seep trends where the geologic model [102] suggests that seepage is extremely unlikely (Figure 12). Specifically, this is over the compressional dropped block that should prevent migration to the seabed. As such, the geological mechanism is unclear, and these seeps were not outlined. Additionally, some surveys were not comprehensive-the 1946 survey includes emissions in Goleta Bay and to the west 


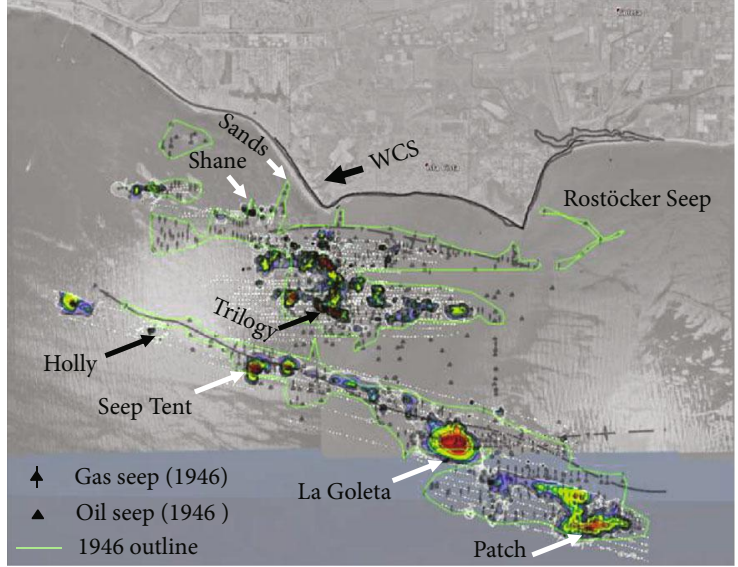

(a)

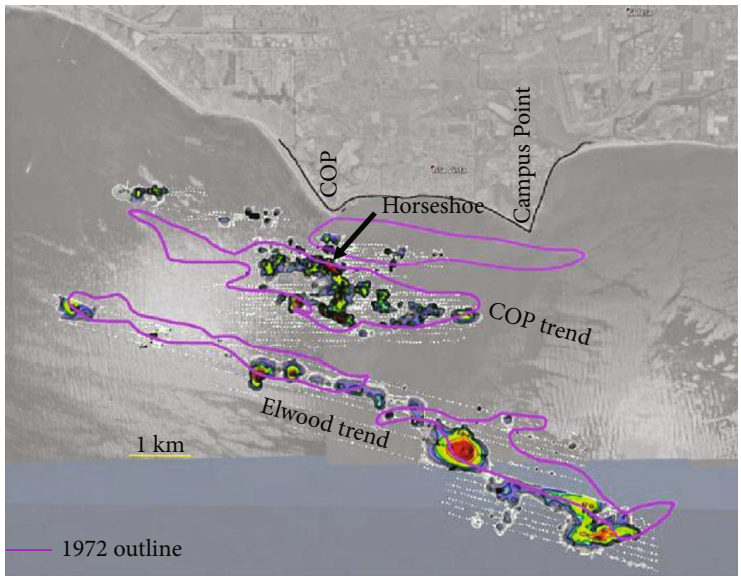

(c)

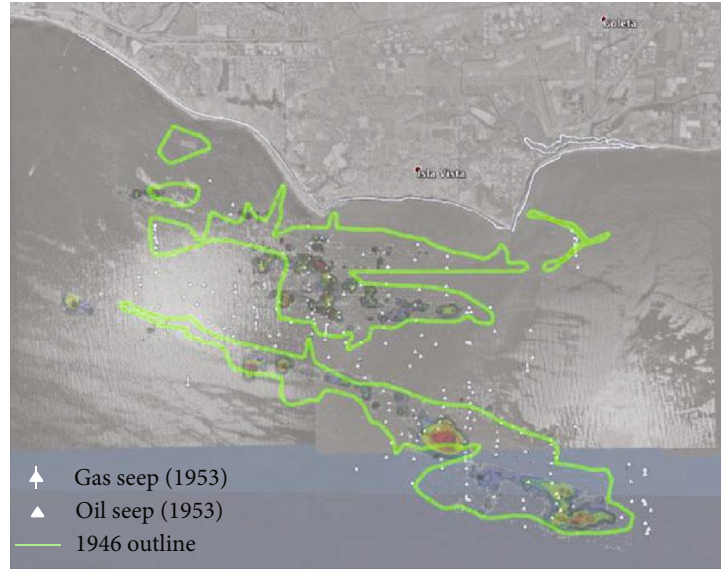

(b)

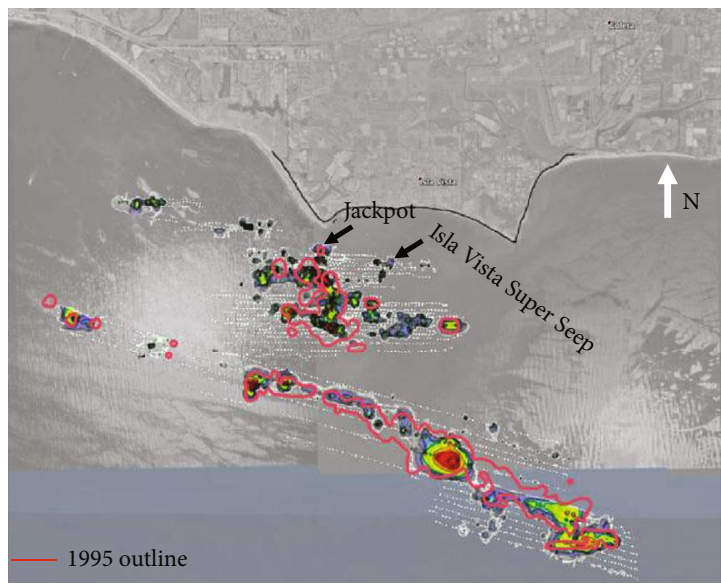

(d)

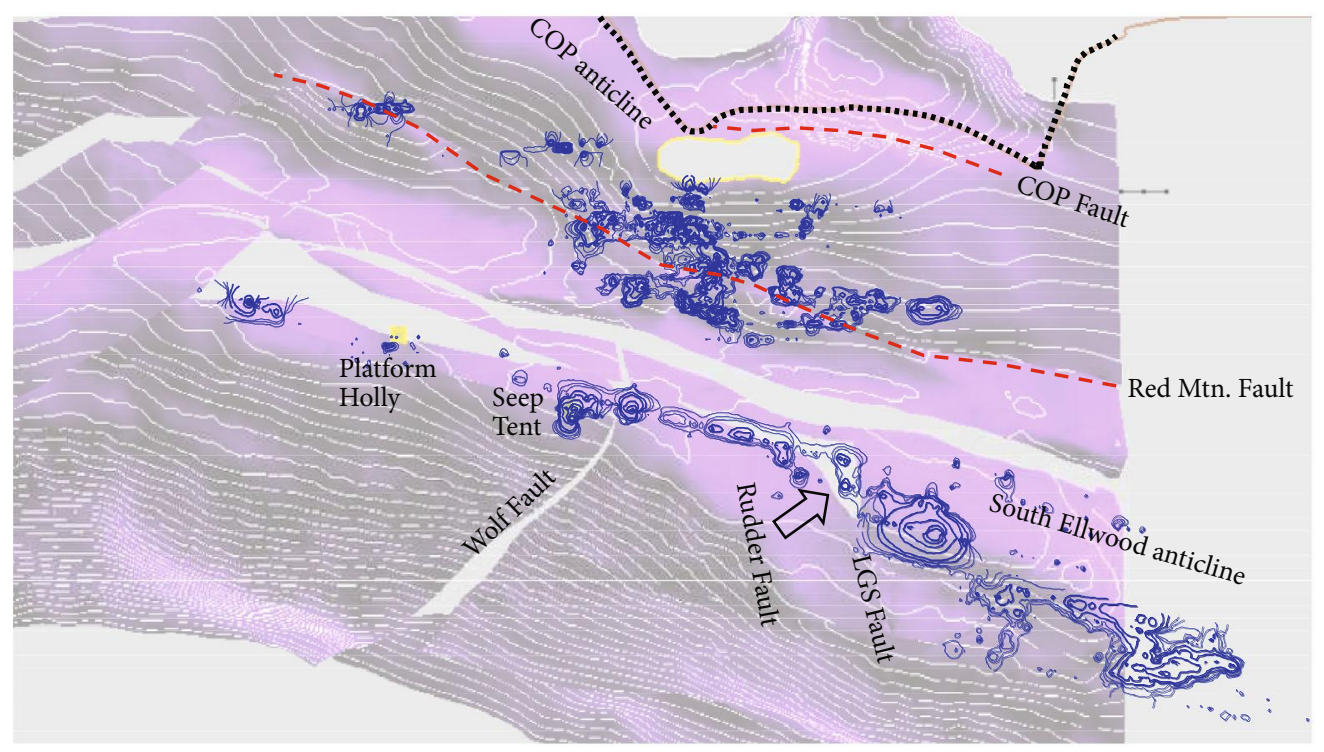

0.150

0.100

0.050

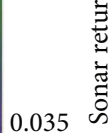

0.020

(e)

FIGURE 18: Sonar return map for 2005 from Leifer et al. [102]; white dots indicate survey lines. (a) 1946 gas seep area outline (this study) and mapped oil and gas seeps; (b) 1953 seep area outline (this study) and mapped gas and oil seeps; 2005 sonar data contrast lowered; (c) 1972 gas seep area outline from Fischer [50]; (d) 1995 gas seep area outline from Hornafius et al. [260]. Displayed in Google Earth showing aerial image from Sept. 1994. (e) Monterey Formation (MF) depth and location of faults and 1995 sonar contours. See Figure 12 for MF depths and geolocation. 
of Shane Seep and in extremely shallow $(\sim 3 \mathrm{~m})$ waters off Sands Beach. The 2005 survey used a near-seabed following window (reducing the impact of dissolution on bubble flux) and was limited to $15 \mathrm{~m}$ deep water, missing the shallowest seeps observed in 1946, some of which are among kelp beds that prevent sonar analysis but not surface visual surveys as used in 1946. The 1995 survey was limited to $\sim 20 \mathrm{~m}$ water and used a sea-surface following window at 15-20 $\mathrm{m}$ deep, which would miss weak seeps that disperse or dissolve during rise and also would have greater spatial uncertainty due to displacement of the plume by currents. The 1995 survey did not map west of COP (e.g., Shane Seep) nor inshore to the east of Campus Point. The 1953 survey reported almost solely oil seeps, and thus, an outline was not developed.

The surveys mapped a significant decrease in the overall seep field area over the 60-year period (Figure 18) as well as for most major seep field areas, albeit nonuniformly. Note that a spatial extent decrease does not necessarily correspond to an emission decrease. Thus, greater emissions can arise from a smaller area if migration pathways of higher permeability develop that rechannel migration from nearby, lower permeability pathways and associated vents.

One possible example is for the field's largest seep, the Seep Tent Seep. The Seep Tent Seep was tented in 1982, with two tents collecting oil and gas that were piped to shore [131]. The Seep Tent Seep appeared transiently in 1970 and then permanently in 1973. Although the Seep Tent Seep area in 1946 included significant oil, few slicks were mapped in the Seep Tent Seep area in 1953. Its appearance corresponded to a reduction of spatial extent from 1946 to 1995 , and the formation of the largest seep in the field, rechanneling emissions from weaker, higher resistance pathways in the area. This is consistent with the resistance model of a high flow/low resistance pathway (Figure 3 ). Similarly consistent, Bradley et al. [53] found in long-term pollution station data (since 1990) that when overall seep field emissions decreased to a minimum in 1995, they were focused on the Seep Tent Seep (Figure 17(c)).

Overall, long-term, continuous WCS data (Figure 17(c)) suggest that field extent correlates with field emissions. Underlying this relationship is the vent activation model wherein increasing emissions activate inactive vents, expanding field extent. Thus, seep field extent is a proxy for seep field emissions, albeit not a strong proxy.

The eastern Ellwood trend features the persistent La Goleta Seep area, whose extent remained similar from 1946 to 1972 (with an eastward offset in 1972 relative to the 2005 survey, possibly from current differences). The La Goleta Seep clearly decreased by 1995 but remained unchanged between 1995 and 2005. Similarly, the Patch Seep area appears largely unchanged over the decades.

The La Goleta Seep lies along a projection of the eastern coast of Campus Point, suggesting that a fault connects the two. Additional support for an unmapped fault is the trend of oil seepage noted in 1946 along this trend, a trend that matches a linear trend of oil seepage in the 1953 survey. Leifer et al. [102] also showed significant control by the Rudder Fault, which crosses the dropped block and transects the Red Mountain Fault and the west edge of the outcropping
(Figures 12 and 18(e)). A combination of flexure in the anticline and intersecting faults at the crest tends to create a damage zone and open fractures allowing migration. The La Goleta Seep connects to the shallowest point of the Monterey Formation anticline-i.e., the top of a hydrocarbon accumulation trap, likely the result of stress from the faults converging on it. Damage zones create numerous migration pathways that apparently allow migration around temporary tar seals. Furthermore, faulting enhances vertical migration within the Monterey Formation (across bedding planes) facilitating accumulation in the formation's crests. The longterm stability of the areal extent of the Patch Seep likely relates to its absence of a focused major seep and proximity to the peak of the Monterey Formation. Specifically, seep area is highly sensitive to the major seep's flux; a small redistribution from a major seep, such as the La Goleta Seep, can activate or deactivate many smaller seeps. In one of the sonar surveys underlying the sonar data presented in Leifer et al. [102], the La Goleta Seep was inactive, and the area of seepage extended to the Wolf Fault, similar to the extent reported in the 1946 surveys. One possible explanation is that the La Goleta Seep was sealed at the time of the survey.

Both the Seep Tent Seep and La Goleta Seep overlie shallow crests on the Monterey Formation anticline, delineated to the north by the multiple parallel faults of the S. Ellwood Fault System and thus are preferential seepage locations. The Seep Tent Seep also is located adjacent to a major crossing fault, the Wolf Fault (Figure 18(e)), similar to the multiple fault intersections for the La Goleta Seep. In 1946, seepage was documented extending along the Wolf Fault, indicating damage zones in the Monterey Formation; however, no focused seepage was noted in 1946, nor was seepage noted in 1953.

For the western area of the S. Ellwood trend, a significant decrease in seepage extent was mapped between the 1970s and 1990s. Quigley et al. [139] identified this as related to production. However, little seepage was mapped here in 1946, highlighting the complexity in the relationship between production and seepage. Specifically, the overall trend is that seepage extent increased with the onset of production from Platform Holly and then decreased afterwards.

The inshore COP trend, which includes the modern Trilogy and Horseshoe Seeps, appears to occupy a similar area extent over the period, with apparent spatial reduction due in part to improved resolution and better mapping accuracy in 2005 than the 1970s. In 2005, more extensive seepage was found than in 1995 and also more focused along the faults controlling seepage from the Trilogy Seep area. The major controlling fault trends towards one side of the Coal Oil Point fault and was active in 1946.

In 1946, two seepage trends were identified in Goleta Bay [138], one of which trends along the east-west trending COP syncline [102] parallel to the Isla Vista coast. This area was not visited in the 1995 and 2005 surveys; however, seepage was identified in 2015 during a campaign to Röstocker seep [70]. This campaign mapped dozens of gas seep vents within an $\sim 10$-meter diameter area. Interestingly, Goleta Bay seepage was identified as oily in 1946 and 1953. 


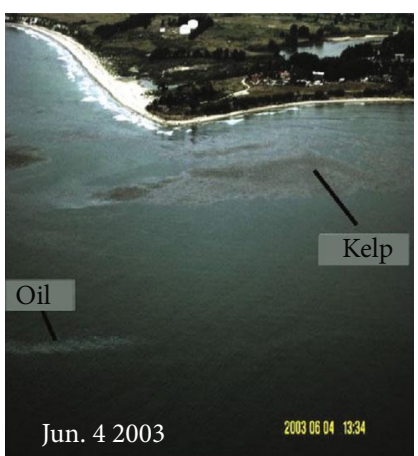

(a)

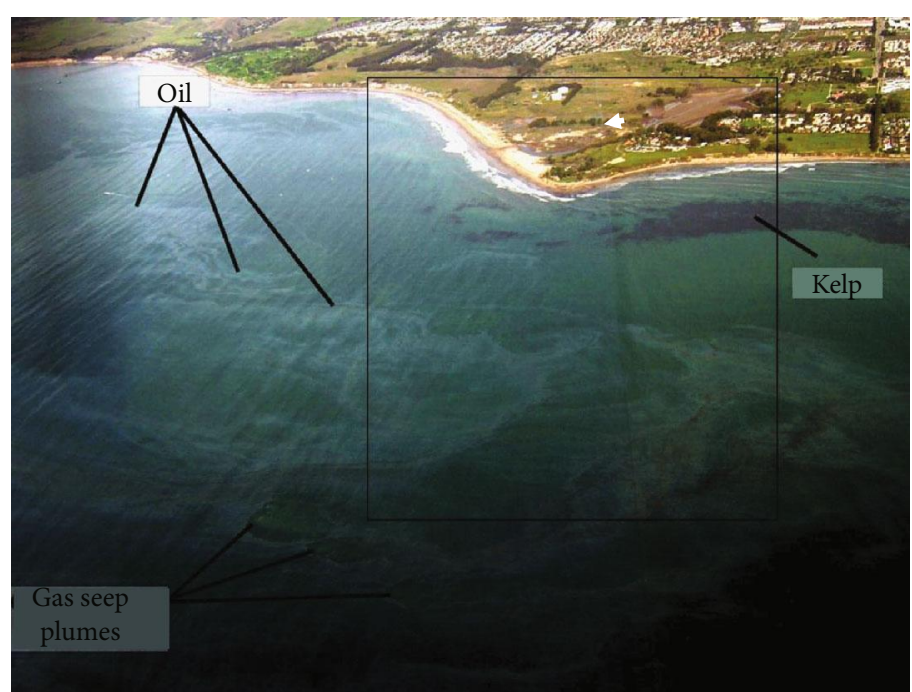

(b)

Figure 19: (a) Extensive oil slicks offshore Coal Oil Point following strong storms in Jan. 2005 and (b) comparison image for Jun. 2003. From Del Sontro [190]. Photo courtesy: Chris McCullough (DOGGR) and Ira Leifer. WCS: West Campus Station, location shown.

Similarly, the Isla Vista Super Seep was oily in the late 1970s [225] emitting oil droplets; however, in the 2000s, it emitted only gas-no surface oil slicks (Ira Leifer, personal observations, 2018). Current analysis of IV Super Seep bubbles observed by video in 2017 suggests that some bubbles are oily (Ira Leifer, unpublished data, 2018).

Oil seepage was reported along linear north-south trends over the dropped, compressional block between the inshore and offshore seep trends south of both COP and Campus Point in both 1946 and 1955. This seepage was not mapped in recent sonar surveys yet is suggested in the 1994 aerial imagery (Figure 18, background image) by a north-south line of oil slicks located to the east of the 1940s north-south trend. The presence of an oil slick absent sonar observations suggests oil emissions with very little to no gas emissions. Alternatively, the seepage could be transient and/or seasonal.

Shane Seep was mapped in 1946 and is suggested in 1953. Currently (Ira Leifer, unpublished observations, 2018), as in the earlier studies, Shane Seep produces oil; however, it was absent in the 1972 map, which included very shallow seepage offshore Isla Vista (even among the kelp beds). During the 2000s, Shane Seep has been a persistent feature and the subject of numerous studies [6,39, $49,114,130,226]$ including mapping in the 2005 sonar survey [102]. These data suggest multidecadal transiency of Shane Seep. Meanwhile, the seepage trend to the west of COP and south of Shane Seep in the 1940s and 1970s has been inactive in more recent decades.

Overall, the changes in area extent are consistent with the 18-year WCS data (Figure 17(c)) that shows a minimum in 1995 , with a general increase thereafter through 2008. Moreover, this increase corresponded to a spatial extent increase of the COP seep trend. These changes are consistent with the resistance model, suggesting that the COP seep field's central migration pathway was the Seep Tent Seep-the strongest seep in the field in the 1990s and 2000s. Seep Tent Seep emissions were estimated by a seep buoy [226] at $5.7 \mathrm{~m}^{3} \mathrm{dy}^{-1}$
(Nov. 2002), slightly larger than the combined emission for the three Trilogy Seeps of $4.8 \mathrm{~m}^{3} \mathrm{dy}^{-1}$ (Sep. 2005) and $3.3 \mathrm{~m}^{3}$ $\mathrm{dy}^{-1}$ (Dec. 2002) for the Horseshoe Seeps.

Frequent field studies in the 2000s observed a significant change first documented in 2005, the appearance of the Trilogy Seeps. Prior work in the 1990s identified the largest inshore seepage as from the Coal Oil Point Seep, which became inactive around 2000 (Thor Egleton, Personal Communication, 2005). The Trilogy Seeps are aligned with the fault that defines the Coal Oil Point. Their appearance was first noted after two exceptional rainstorms in January 2005, during an airborne survey of massive oil slicks off Coal Oil Point (Figure 19). Although rain from these storms was exceptional, an associated swell was typical for major Southern California storms. Thus, Del Sontro [190] proposed aquifer recharge, whereby rain enters onshore aquifers that extend offshore, increasing pressure in the reservoir and/or migration pathways, leading to the opening of new migration and seepage along the Trilogy Seep trend. This event was accompanied by exceptionally extensive thick oil slicks (Figure 19). When a deactivated seep (probably from tar and oil deposition in migration pathways) is reactivated, the plug of oil and tar can be ejected, driving significant oil emissions. Such emissions also can occur from tectonic activities. For example, area beaches were reported covered by thick tar oil matts at the time of the 1925 Santa Barbara earthquake [227].

\subsection{Transport and Evolution of Coal Oil Point Seep Oil}

2.5.1. Overview. Winds and currents drive oil slick transport, with currents comprising bulk currents, tidal currents, wind-driven surface currents, current shears, convergence flows, and Langmuir circulations. As the oil is transported, it rapidly emulsifies (if not a sheen) and loses its more volatile components to evaporation. Evaporation increases rapidly with temperature and thus is slower at night and during winter. For reference, the volatile component of oil 
$\mathrm{N}$

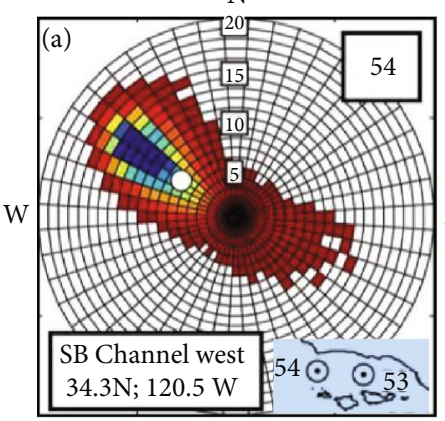

S

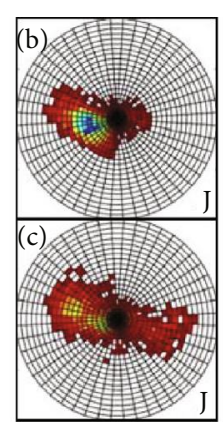

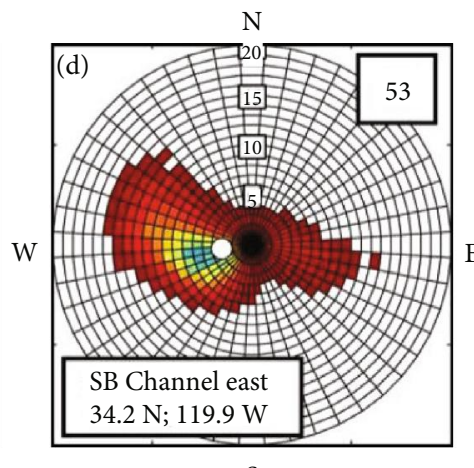

$S$

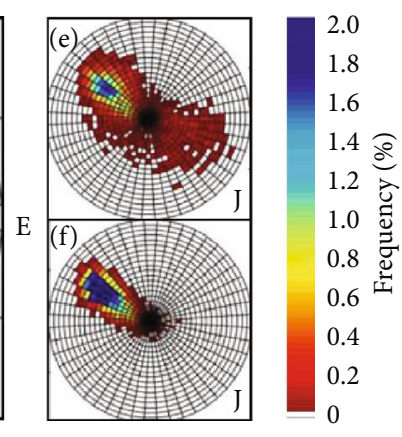

1.4
1.2
1.0
0.8
0.6
0.4
0.2
0

Figure 20: Wind roses for the NOAA East (46053 - labeled 54) Channel buoy for (a) full year, (b) winter (January), and (c) summer (June) and West (46053 - labeled 53) Channel buoy for (d) full year, (e) winter (January), and (f) summer (June). Adapted from Beckenbach [230].

from the COP seep field and for typical temperatures is reported at 30\% [228]. Loss of the lighter components increases oil density and viscosity. With increasing viscosity, the oil becomes less mobile, spreading less and coalescing into thick slicks, i.e., spreading is constrained. With increasing density, the oil becomes less buoyant, eventually sinking and drifting as submerged oil.

In the following sections, we describe oil transport at the sea surface as fresh oil slicks, (Section 2.5.2, 2.5.3), its loss to the water column through sinking (Section 2.5.4), its transport and accumulation on area beaches (Section 2.6), and its proposed offshore transport after removal from the beach by subsequent high tides (Section 2.7 ).

2.5.2. Winds in the SB Channel. The meteorology of the Santa Barbara Channel results from the coupled interactions between the lower troposphere, ocean, and coastal mountain ranges [229] - the east-west trending Santa Ynez Mountains along the Northern Santa Barbara Channel ( 1,300 m high) including directly north of the COP seep field. These mountains shelter the Santa Barbara Channel, particularly its northern edge [230]. On large scales, the semipermanent, eastern Pacific high-pressure system plays a dominant controlling role in coastal weather from the Santa Barbara Channel to the Los Angeles Basin. This high-pressure system drives weak winds and strong temperature inversions that act as a lid, restricting convective mixing to lower altitudes, i.e., a shallow planetary boundary layer [231].

Prevailing winds are from the northwest with weaker and far less frequent winds from the east-southeast. Winter prevailing winds are primarily from the west with very infrequent and weak easterly winds. Prevailing summer winds are from the west-northwest with significant winds from the east-southeast (Figure 20). Winds from the south and from the north are very infrequent and weak. Prevailing east channel winds are more closely aligned with the transverse mountain range-east/west-than for the west channel.

The strongest winds tend to occur in early afternoon, particularly in spring, and the weakest winds in the early morning (Figure 17(d)), especially during winter, with $60 \%$ of presunrise hours during November and December being calm [230]. Sometimes, stronger winds (particularly westerlies) continue into early evening and later, occasionally until after midnight. Land-sea breeze circulation patterns result in a diurnal reversal with gentle nighttime downslope subsidence flow. Nearshore local variations occur for canyon flow, with channelized winds flowing offshore based on topography. Canyon flow winds control near coastal winds, shifting prevailing winds further offshore [232]. Canyon flows are not dominant around the COP seep field but do occur at multiple locations to the west and east. For example, the Gaviota Pass $(\sim 30 \mathrm{~km}$ west of COP) is well known for extremely strong wind outflows late into the night $[233,234]$.

An alternate wind pattern of strong offshore flow occurs in fall and winter, the Santa Ana winds. The Santa Ana winds are strong, mountain lee side, surface-following winds. Santa Ana winds are driven by synoptic-scale pressure and/or temperature gradients between the coast and the interior desert [235], reaching hurricane strength in some locations [232]. The Santa Ana winds push the normal sea breeze and prevailing winds offshore, with the latter reasserting themselves once the Santa Ana winds diminish, typically fater one to three days (1.5 day mean), although Santa Ana winds can persist up to five days [232]. As with canyon flows, Santa Ana winds tend not to occur around Santa Barbara but do occur to the east and west. Thus, Santa Ana winds primarily affect the COP seep field by the swell they generate.

Another key meteorological feature of the coastal Santa Barbara Channel is the cool, dense marine atmospheric boundary layer, which is particularly important in the summer when its thickness varies from 300 to $350 \mathrm{~m}$ for late morning to late afternoon, thinning significantly at night [229].

\subsubsection{Currents in the Santa Barbara Channel. The Santa Bar-} bara Channel (Figure 21) is an east-west trending body of water defined at the north by the California mainland coastline and to the south by the Channel Islands [236]. Combinations of structural and depositional features control its bathymetry. The Channel's east entry is narrow and shallow whereas the western edge is relatively broad and deeper. Two dominant regimes control Channel currents, the southward flowing offshore California Current that originates in the North Pacific and the northwards flowing, warm, inshore Davidson Current (also the California Undercurrent). Due to the shoreline orientation shift from north-south to east- 


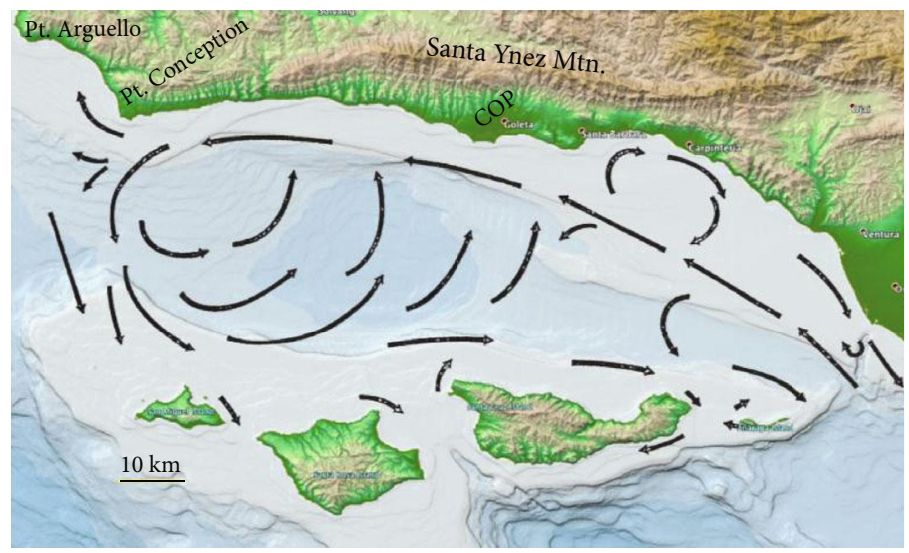

(a)
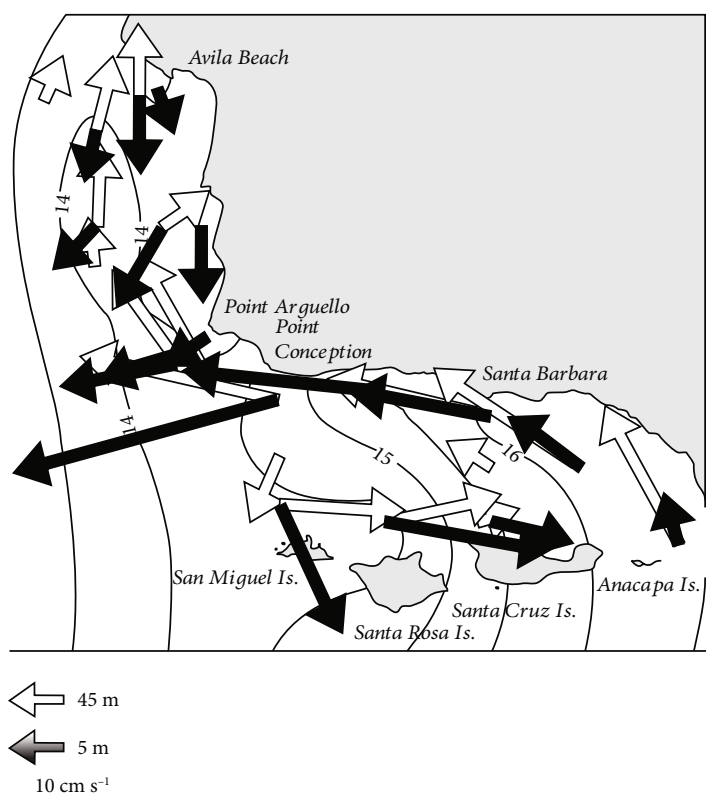

$\mathrm{cm} \mathrm{s}^{-1}$

(b)

Figure 21: (a) Santa Barbara Channel bathymetry and generalized currents. Adapted from Divins and Metzger [261] and Kolpack [236], respectively. (b) Annually averaged temperature contours and annual mean current at 5 and $45 \mathrm{~m}$ depth. Adapted from Winant et al. [237].

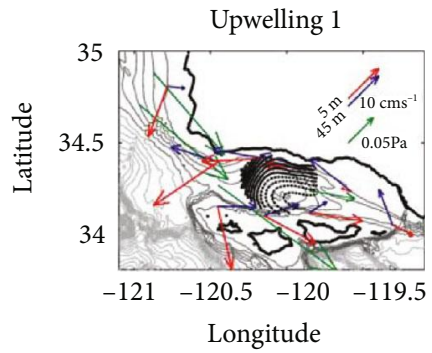

(a)

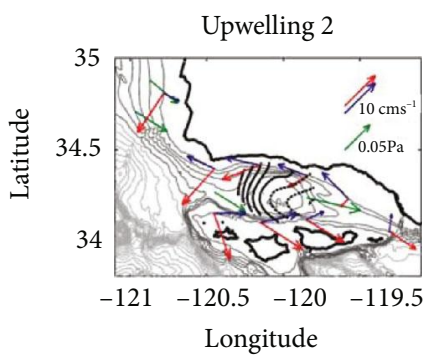

(c)

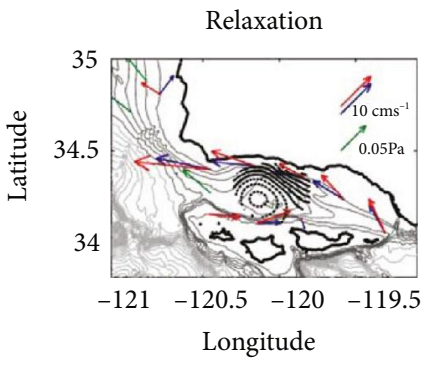

(b)

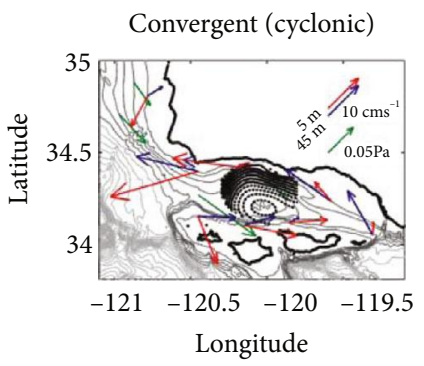

(d)

Figure 22: Mean wind stress patterns, currents, and CODAR flow patterns for (a) upwelling 1 and (b) relaxation, (c) upwelling 2, and (d) convergent flow patterns. See text for details. Current data from Oct. 1992 to Jan. 1996 also shown. Data key on figure. After Beckenbach [230].

west from the west to the east of Point Conception, much of the California Current bypasses the Channel; however, some portion enters on the channel's southern margin, flowing along the islands.

These two currents define a channel-scale counterclockwise eddy at shelf depth or less [237]. This eddy slowly propagates westwards and is replaced by a new eddy at the east after leaving the channel with a 10-20-day cycle. Due to blocking by the Channel Islands, swell arrives primarily from the west, driving an eastward, longshore current that opposes the westwards alongshore flow from the Davidson Current. In combination with the presence of coastal irregularities (points), this supports the formation of small-scale clockwise eddies along the Oxnard-Santa Barbara coast. During winter, the Davidson Current continues up the coast around Point Conception, whereas in the summer, it joins the counterclockwise circulation at the western boundary of the Santa Barbara Channel. 


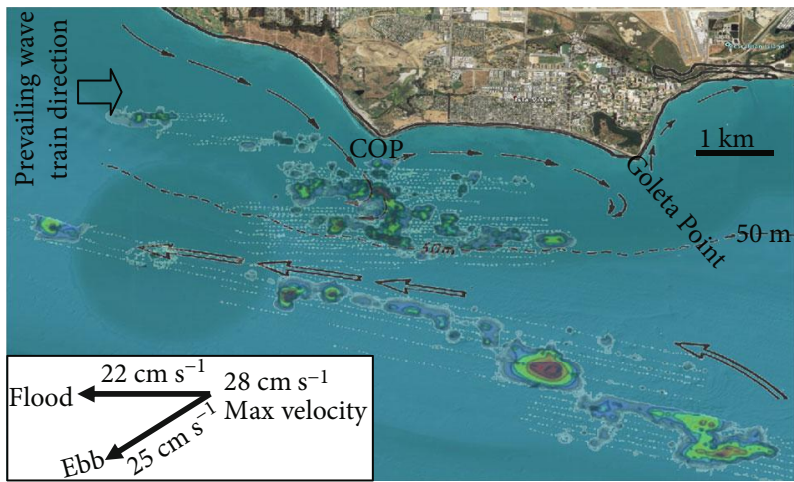

FIGURE 23: Generalized nearshore currents (not surface) for the COP seep field area showing generalized offshore currents for the COP seep field. COP seep field sonar map for 2005 added for spatial reference (see Figure 18 for sonar legend). Currents based on Fischer [50].

Near-surface water currents (Figure 22) are affected by basin currents and surface winds (generally westerly-Figure 20) with important seasonal variations. Winant et al. [237] identified three patterns-upwelling, relaxation, and convergent. Each pattern persists for several days and exhibits clear seasonality in occurrence rates. Upwelling occurs when Santa Maria Basin currents and winds are to the south with water flow through the channel exiting to the southeast from the eastern Santa Barbara Channel. Relaxation is the reverse of upwelling with north flow in the Santa Maria Basin and inflow from the east into the channel. Convergent flow occurs when the weak winds combine with southward flow in the Santa Maria Basin, currents flow westwards at Point Conception, and currents flow northwest alongshore in the east channel [237]. Convergent flow leads to strong cyclonic circulation in the channel, particularly at $5 \mathrm{~m}$ depth. Beckenbach [230] also identified a second upwelling pattern (Figure 22(c)) under weaker southeast winds that featured greater surface current outflow to the east.

Upwelling generally occurs late winter through early summer when winds are stronger (Figure 22) and generally transports water eastwards [237]. Relaxation generally occurs late summer through early winter during periods of low wind stress and generally transports water westwards. The convergent pattern is equally likely year-round and accompanies strong westward flow along the northern channel coastline.

Swell generally arrives from the west, driving a strong, eastward longshore current along the beaches west of COP, which is significantly weaker for the sheltered beaches east of COP (Figure 23). Sharp shifts in beach orientation (e.g., $\mathrm{COP}$ ) induce a strong wave-stress gradient around the point, which generates rip currents [184]. Observations confirm a strong offshore flow (to the south) from COP with velocities to 22 and $25 \mathrm{~cm} \mathrm{~s}^{-1}$ for the ebb and flood tides, respectively [138]. These offshore currents flow southwards down the west flank of the submerged ridge south of COP [102] that extends to Trilogy Seep, removing sediment. For example, Jackpot Seep in $15 \mathrm{~m}$ of water is observed to have exposed tar mounds and just centimeters of sand above rock [39, 57], and low tide exposes formation rock at COP. This offshore flow merges with the Davidson Current that follows the coast to the west. These currents transport submerged tar and sediments offshore, beyond the shoaling region (Figure 8), as well as removing sand and exposing rock.

2.5.4. Sinking/Dispersing Seep Oil. COP seep oil primarily rises buoyantly on bubbles or as droplets to the sea surface where it forms surface slicks. The nonvolatile oil slick components then either wash onto nearby or more distant beaches, sink and deposit into seabed sediments, form tar balls, or disperse into the water column and ultimately drift out out of the channel. Partitioning between these fates is largely unknown, although the lack of significant permanent stranded tar on Santa Barbara Channel area beaches [189] demonstrates that beach deposition plays only a transient role in COP seep field oil's fate.

Although poorly documented, sinking appears to play a critical role in the fate of COP seep field oil slicks. The initiation of oil sinking has been observed during slick tracking studies, e.g., Del Sontro [190] and Leifer et al. [6], and is a major finding of Del Sontro et al. [189, 190], specifically, that low wind speeds allow slicks to remain undispersed and provide more time to reach the beach, increasing beach tar accumulation.

Weathering and subsequent oil sinking also were documented during an oil booming experiment in the COP seep field (Figure 24), described in McClimans et al. [238]. This experiment tested a bubble oil boom mounted on two oil booms connected in a U configuration. Sinking oil was documented by underwater video of the oil collected in the boom and for the oil slick near the seep bubble plume. This experiment followed a prior effort (Figure 25) to use an oil boom to collect oil during which the oil sank after one to two hours.

In addition, during several slick-tracking experiments (Leifer, unpublished observations), it was observed that about an hour after the morning fog (also termed "marine layer") clears, oil slicks weather to where the slightest disturbance causes dispersion, i.e., the oil does not resurface. In contrast, entrained oil from a similar disturbance an hour prior would have resurfaced. These observations are consistent with photooxidation fragmenting larger hydrocarbon molecules into smaller ones that evaporate (Section 1.4.3), increasing the oil's density until its buoyancy is neutral to negative and it sinks. Typical channel winds are calm in the morning, strengthening into the afternoon, 


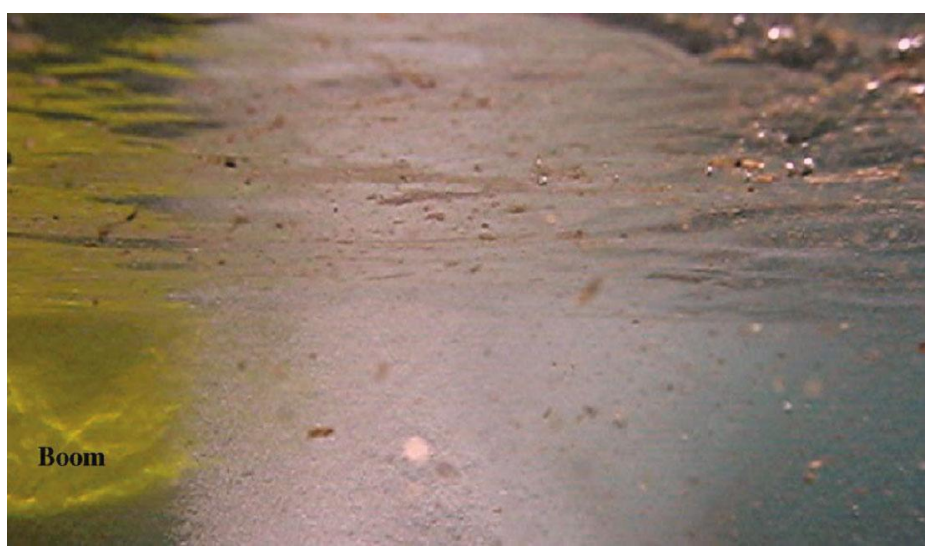

Figure 24: Image of submerged (dispersed) oil in the Coal Oil Point seep field during a bubble oil boom test, described in McClimans et al. [238]. Foreground oil emulsion globules are a few millimeters across. Photo is red contrast-enhanced to highlight oil. Photo: Ira Leifer.

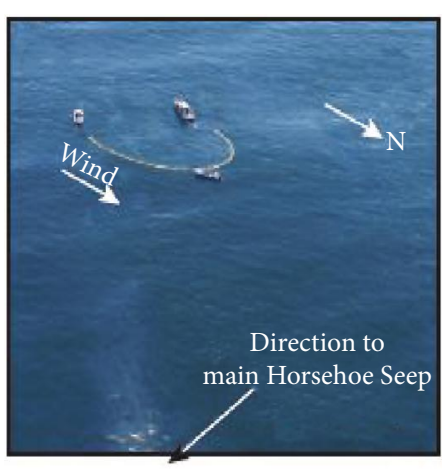

(a)

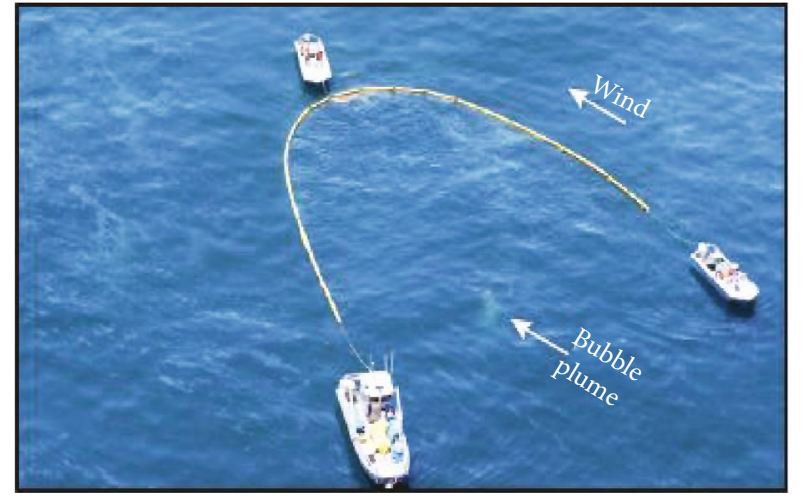

(b)

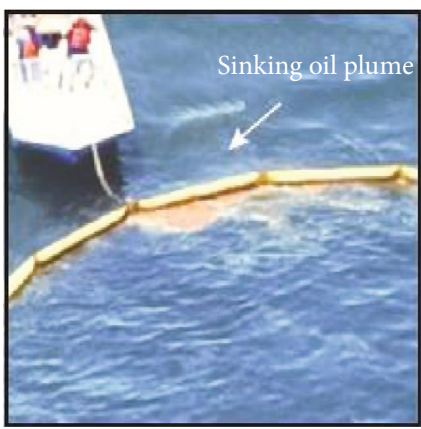

(c)

Figure 25: (a, b) Photos of a seep oil assessment experiment for a single, isolated seep plume near Horseshoe Seep. (c) Zoomed image of collected surface oil. From Lorenson et al. [125]. Photo courtesy: Chris McCullough, California Dept. of Conservation.

and with whitecap wave breaking common in the mid- to late afternoon. As waves develop and winds strengthen, dispersion begins.

Submerged oil can sink to the seabed and become buried under sediments. Farwell et al. [239] reported a "sediment hydrocarbon plume" or a "plume-shaped" area of sediment where hydrocarbon concentrations were elevated, stretching tens of kilometers to the west of the COP seep field. The plume was mapped from 15 sediment samples with a halfwidth of $\sim 1-2 \mathrm{~km}$ and extends for $\sim 5 \mathrm{~km}$ to the west of the field (i.e., $5-10 \mathrm{~km}^{2}$ ) where concentrations decrease abruptly. Further to the west, a weak plume of near background concentrations continues to $\sim 30 \mathrm{~km}$ from the COP seep field (near Gaviota). The plume's hydrocarbon mass was estimated $0.3-3 \times 10^{6} \mathrm{~m}^{3}$, equivalent to $50-500$ years of COP seep field emissions based on the Hornafius et al. [40] estimate of $100 \mathrm{bbl} \mathrm{oil} \mathrm{dy}{ }^{-1}\left(\sim 6,000 \mathrm{~m}^{3} \mathrm{yr}^{-1}\right)$ for the COP seep field. Yet, the seep field has been active for at least 500,000 years [192] implying several cubic kilometers of emitted asphalt, at least. The absence of extensive subaerial tar reefs or a tar island downcurrent of the COP seep field indicates that the vast majority of emitted seep oil is transported out of the Santa Barbara Channel either directly or after a relatively short sediment residence time (compared to the field lifetime) in this downcurrent sediment plume. In the latter case, the plume should not show an abrupt decrease at $\sim 5 \mathrm{~km}$ but should decrease continuously and gradually to the west. One possibility unaddressed in Farwell et al. [239] is that the far field, weak sediment plume likely originates from the Cojo and Conception seep fields. Lorenson et al. [125] reports larger beach tar accumulations from Point Conception area seeps, indicating a need to address the contribution of non-COP seep field seepage to regional sediment petroleum loads. Additionally, the structural strength of asphalt tar mats is such that a mechanism for liberating it from near-field buried sediments at 40$100 \mathrm{~m}$ depths is unclear-seabed tar formations near Point Conception clearly are robust against storms.

Comparison between the sediment plume volume and seep field emissions implies that a very small fraction of overall field emissions are buried in downcurrent sediments. When oil sinks or disperses naturally, it is slightly negatively buoyant-likely comparable to marine snow and smaller MOS $[173,240]$ which settles at $\sim 75 \mathrm{~m} \mathrm{dy}^{-1}$. This requires $1 / 2$ to 1 day to reach the seabed for the sediment plume's water depths (50-100 m). At typical currents of 10-20 $\mathrm{cm} \mathrm{s}^{-1}$ [241], dispersed oil drifts from 5-8 to $8-17 \mathrm{~km}$ in these time period ranges, i.e., it would reach the seabed significantly downcurrent of the observed plume. Farwell et al. [239] used a much faster settling 


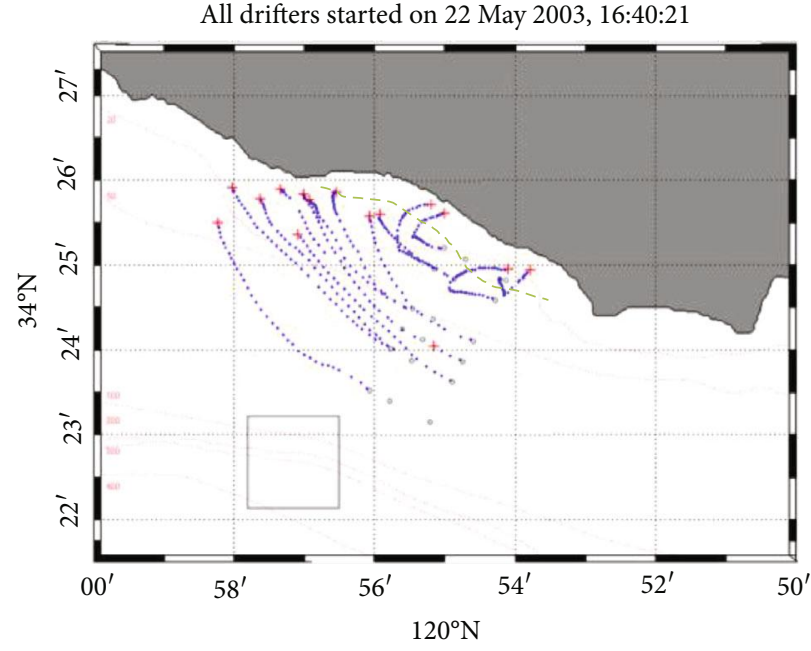

(a)

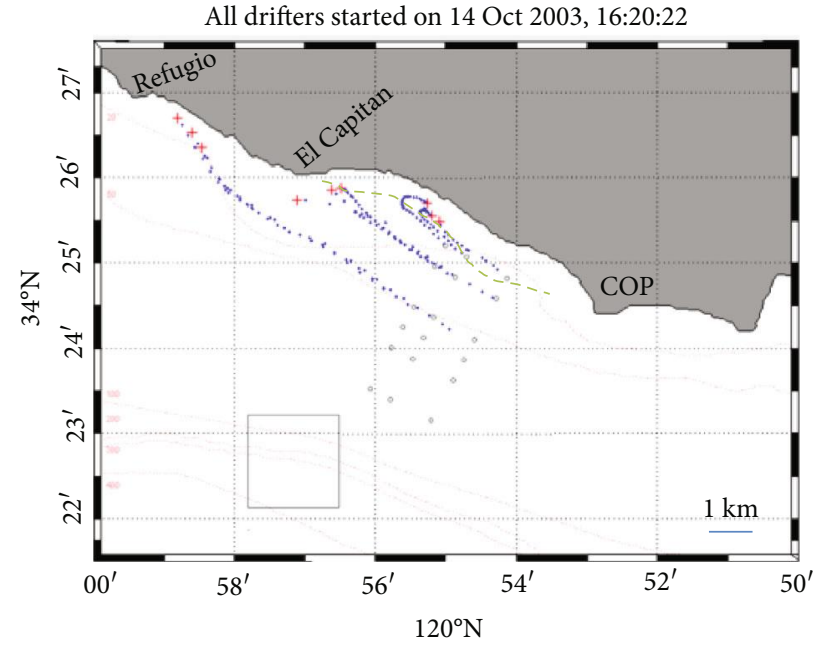

(b)

Figure 26: Drifter data for Santa Barbara Channel, west of Coal Oil Point (COP). Dashed green line shows where offshore currents shift to an inshore countercurrent. Box shows CODAR coverage. Adapted from Ohlmann [241].

rate which requires a hypothesized direct-sinking mechanism. This mechanism is termed in this review for discussion purposes but was not explicitly proposed by Farwell et al. [239]. Alternate mechanisms include (infrequent) storm mixing that extends the wave-mixed layer, typically $20-40 \mathrm{~m}$ in the Santa Barbara Channel ([230]; Figures 2-11), to the seabed, or from remobilized beach tar, discussed in Section 2.6.

A more plausible hypothesis is that under typical (nonstorm) Santa Barbara Channel conditions, the majority of dispersed COP oil remains in the wave-mixed layer, forming oil mineral aggregates with sediment (OMA) or with algae and microbes (MOS) that slowly sink while drifting west with the Davidson Current into the open Pacific Ocean, and/or recirculated by the Santa Barbara gyre into the California Current and then drifting south and east.

Under the very infrequent stormy conditions in Santa Barbara, the wave-mixed layer extends to the shallow seabed, mixing oil directly to the seabed, as well as forming fast-settling (large) OMAs with storm-mixed sediments. Thus, storms could provide an efficient deposition mechanism. The storm deposition hypothesis could explain in part the several orders of magnitude mismatch between seep field emissions and the sediment plume's mass based on the infrequency of storm$s$-one to three per year - but OMAs would have to permanently deposit into sediments - equally likely storm-disturbed sediments could resuspend sediment oil into the water column.

\subsubsection{Generalized COP Seep Oil Transport. The fate of COP} seep field oil depends on currents (Davidson Current, longshore current, nearshore countercirculation eddies, and wind-driven surface currents) and winds.

Data from West Campus Station, $\sim 1 \mathrm{~km}$ inshore of COP (see Figure 19 for location), show that typical overnight, near-coastal winds are weakly offshore-i.e., north winds [53]. In the morning, these winds tend to shift to weak easterly $\left(\sim 2 \mathrm{~m} \mathrm{~s}^{-1}\right)$. Nocturnal stratification breaks down mid- to late morning, often in tandem with the lifting of low, marine layer clouds, and winds shift to southerlies. By late morning to early afternoon, winds shift to prevailing westerly and strengthen (to $4-9.5 \mathrm{~m} \mathrm{~s}^{-1}$ ).

Thus, the typical pattern is the formation of a series of quasiparallel, along-coast oil slicks oriented west-northwest arising from different active portions of the seep field once winds calm down in early evening ( 18:00 PST). Absent wind forcing, oil slicks cannot approach land [178]. Thus, the late morning shift in winds towards the coast is critical to driving alongshore-oriented slicks to the beach. As winds then veer to westerlies, the slicks (which remain aligned with the coastline) drift towards COP. Supporting this transport is a counter circulation eddy (which lies inshore of CODAR current data, which begins $3 \mathrm{~km}$ offshore [230]) that has been documented by drifter studies (Figure 26).

Winds compress the oil slicks into streamers due to higher wind stress at the slick's leading edge (where the sea surface is mobile) than over the slick where oil suppresses capillary waves [179] and renders the sea surface immobile. This change in boundary condition changes momentum transfer from winds to the slick, causing slick aggregation.

If conditions are such that oil weathering is slow, oil washes ashore onto area beaches in pulses corresponding to different streamers associated with different seep sources in the seep field. Offshore, the Davidson Current transports oil slicks westward, which shifts in the shoaling zone to an eastward transport by the longshore current. Complementing the longshore transport is onshore transport by the sea breeze and the counterclockwise inshore eddy, which advects oil slicks into the surf zone. In the surf zone, wave breaking fragments the oil slicks. Del Sontro [190] found that the tar size distribution depends on the wave height (i.e., breaking wave energy). Surface water transport in the surf zone drives oil towards the swash zone where the oil strands as tar balls on the beach.

There are several atypical wind patterns that affect the oil's fate, including calm winds all day, strong prevailing winds into the night, and storm winds. For calm winds, there are necessarily no onshore wind components and the oil does 
not approach the shoreline, drifting westwards along the coast. If foggy and cold, oil can drift tens of kilometers on the sea surface, e.g., Estes et al. ([242], Fig. 3), whereas if warm and sunny, sinking occurs close to the seep field-e.g., Leifer et al. [6].

If strong prevailing winds continue through late evening, COP seep oil can be driven far east. For example, floating, oil slick streamers tens of meters to hundred meters long are observed offshore Santa Barbara early in the morning (Leifer, personal observation, 2016). Oil that is driven this far east contributes to beach tar accumulations between Santa Barbara and Goleta, where COP seep field tar balls are found [125].

Both field observations and quantitative assessment of beach tar (Section 2.6) suggest that a significant fraction of the COP seep field oil sinks after weathering rather than reaching area beaches. Westerly afternoon winds can drive freshly surfaced seep oil eastwards with some of the oil drifting back across the COP seep field. Afternoon winds very often cause wave breaking, which disperses fresh oil subsurface into the wave-mixed layer of the upper water column [172]. This submerged oil then drifts with the upper water column, whose current is coupled to the winds (if winds are strong). Dispersed oil remains in suspension by wave-breaking turbulence [172] and Langmuir circulation $[153,243]$ until winds die down and the oil resurfaces if still buoyant, i.e., it has not yet formed oil mineral or oil marine snow aggregates.

\subsection{Beach Tar}

2.6.1. Overview. Tar is common on southern and central California beaches due to chronic oil emissions from natural oil seeps in its petroliferous regions [6, 125, 191, 244]. Given their proximity to the COP seep field, COP beaches have among the heaviest tar accumulations along the United States west coast [244]. Beach tar accumulation depends on three factors-source strength, transport, and residence time.

Surface oil slick and tar ball transport depend on the combined effect of surface currents and winds, typically calm overnight with currents transporting the oil along the coastline-to the west-northwest and towards shore by the sea breeze and prevailing westerlies. The nearshore current flow field is complex, particularly due to a clockwise recirculation eddy inshore of a rough line between COP and the El Capitan Beach (Figure 26). Thus, once winds transport the oil slick into the eddy, currents are aligned with the prevailing wind or the sea breeze and the oil drifts towards the beach more quickly. Due to blocking by the Channel Islands, swell is from the west, impinging most strongly on Sands Beach to the west of COP and far more weakly on Devereaux Beach to the east (Figure 27). Thus, beach orientation ensures longshore transport from the west towards COP, which protrudes offshore into this current's path. On a small scale, rocky outcroppings directly south of COP are exposed at low tide, affecting tar accumulation.

2.6.2. Beach Tar Study Approach. In the only published quantitative longitudinal beach tar study, Del Sontro [190] and

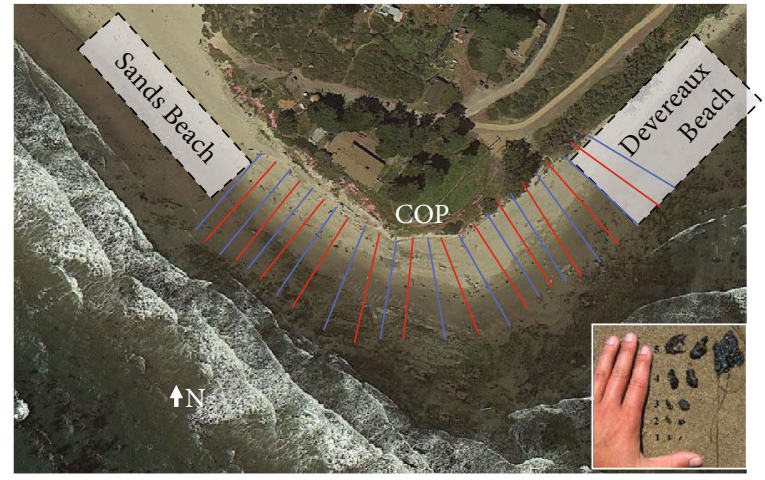

FIgURE 27: Location of transects 1-12 for COP and coverage by $2 \mathrm{~m}$ quadrats as used in beach tar surveys. Inset: example images of tar ball size classes 1-5.

Del Sontro et al. [189] surveyed a $200 \mathrm{~m}$ beach swath centered on COP along 12 transverse transects separated by $10 \mathrm{~m}$ at the top of the beach (Figure 27). Surveys laid a transect tape from rebar that was hammered into sand at the base of the bluffs (to ensure repeatability) at the top of the beach into the swash zone. All tar balls in $2 \mathrm{~m}$ quadrats for each transect were counted for 4 size classes. Larger tar balls' (class 5) dimensions were measured with a ruler and recorded. For each of the size classes (1-4), 100 tar balls were collected and weighed to determine the average mass for each class. The 100 tar balls then were dissolved, and the tar size class mass was corrected for aggregated sediment-i.e., the remains after filtration. Masses for classes 1-4 were $0.006 \pm 0.0035$, $0.022 \pm 0.011,0.073 \pm 0.037$, and $0.169 \pm 0.096 \mathrm{~g}$, respectively. Equivalent sizes for classes $1-4$ were $0.125,0.250,0.500$, and $1 \mathrm{~cm}$ radius. The standard deviation represents the size range defined for each class. To estimate beach coverage, the number of tar balls in each class is multiplied by the class surface area assuming a cylindrical shape. Larger tar balls in class 5 are assumed to have a density of $1 \mathrm{~g} \mathrm{~cm}^{3}$ for mass, and their surface area is measured and used for the class 5 surface area.

A total of 57 irregularly timed surveys were conducted in 2005, reported in Del Sontro et al. [189]. Additional surveys were conducted through 2009, reported in Lorenson et al. [125]. The study ended in 2011, for a total of 187 surveys. Data were analyzed to determine total tar mass for the study area and secondly to determine total tar coverage and mass in tar aggregations - tar is highly unevenly distributed with distance from the swash zone on the beach. For tar aggregations, the total area of tar in contiguous quadrats and nearcontiguous quadrats (allowing for only $2 \mathrm{~m}$ of contiguous tar-free beach within an aggregation) is calculated and normalized to the contiguous area. Note that data are from perpendicular transects that sample along-beach aggregations and thus do not provide information on the tar aggregations' along-beach continuity and extent. Values are reported as mass per linear meter of beach and fractional area.

2.6.3. Beach Tar Seasonality. Summer beach tar accumulation is higher than winter accumulation (Figure 28), a similar seasonal trend that was for Santa Monica Bay-higher tar 


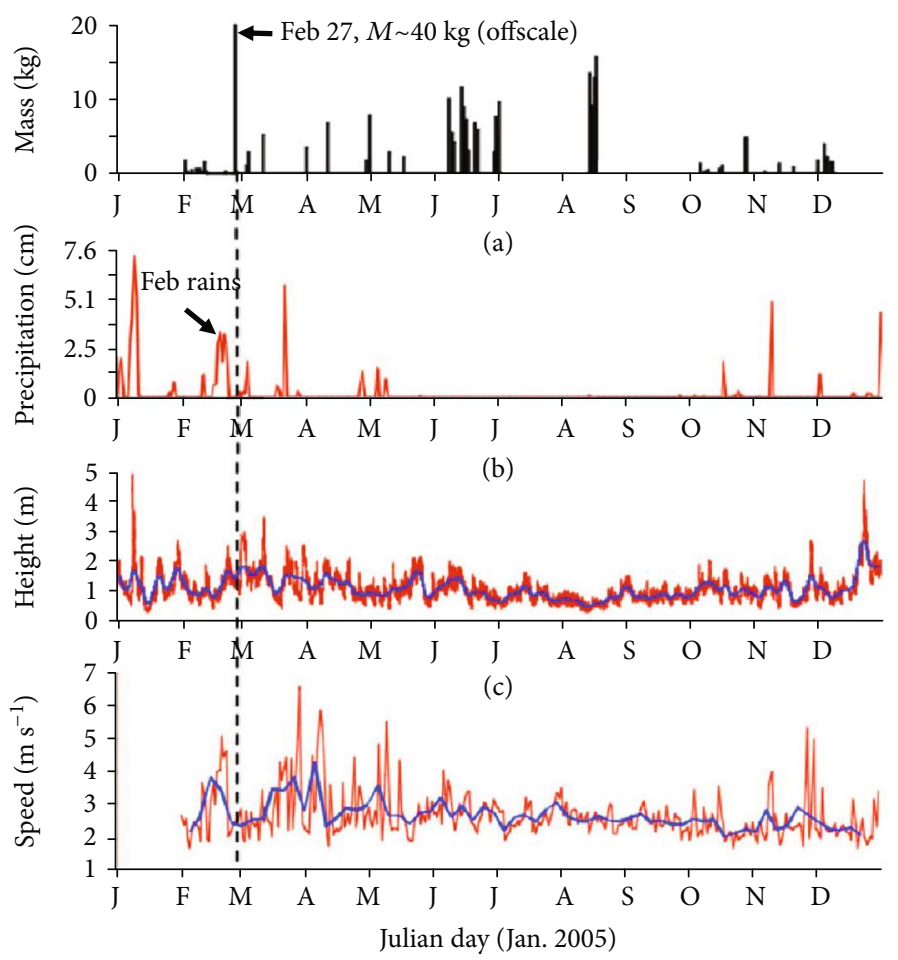

(d)

Figure 28: Beach study area tar (a) mass accumulation (M), (b) precipitation at West Campus Station, (c) swell height, and (d) daily and 5-day averaged wind speed. Adapted from Del Sontro [190].

accumulation in summer and spring than fall and winter [191]. Hartman and Hammond [191] identified tar transport from the COP seep field as underlying the seasonal variation. Specifically, Hartman and Hammond [191] proposed that COP seep field oil travels to the western boundary of the Santa Barbara Channel during spring and summer where offshore flow associated with northerly winds and the channel gyre transports the oil south into the California Current that then transports it eastwards towards Santa Monica Bay. They proposed that during winter, the offshore gyre flow does not capture tar from the northerly Davidson Current, leading to COP seep oil drifting northwards. More recent understanding of currents in the Santa Barbara Channel [237] indicates that transport to Santa Monica Bay relates to upwelling (late winter-spring) and convergent (all year) current patterns (Figure 22). Given that weathering is strongly temperature-dependent, seasonal temperature cycles likely also are important, discussed below.

Important differences between winter and summer include temperature (cooler winter implies slower weathering), winds (stronger winter winds imply reduced transport time to beaches but also more days with wave breaking and sinking), and low clouds associated with the atmospheric marine layer (less marine layer (as occurs in winter) implies more photooxidation and sinking). Whereas cooler winter temperatures increase the likelihood of oil reaching the beach than in summer, reduced marine fog (mostly summer) counters this as does wave breaking and sinking from higher winds.

For long-range transport, losses from photolysis and wave breaking during the multiple days of transport and interaction with currents likely are dominant. For shortrange transport (i.e., from the COP seep field to nearby beaches), other slick processes are more important and the dependency on winds is complex $[5,6]$.

Specifically, coastal marine winds exhibit clear diurnal cycles including sea and land breezes as well as prevailing winds and nighttime decoupling of surface winds from upper level winds. Additionally, the strengths of these winds and the timing of shifts exhibit seasonal cycles. Del Sontro [190] found that the strongest factor affecting COP tar accumulation was the wind speed approximately 10 hours prior to the surveys. This is consistent with the typical transport pattern summarized in Section 2.6.1. Specifically, whether evening winds were strong (or weak) leads to long (or short) eastward oil advection, which if strong enough may lead to permanent loss by dispersing the water column. This evening pattern is followed by westward drift after winds diminish at night. The sooner winds die down, the less time fresh oil is advected eastwards and then to drift to the west where it is positioned for daytime advection onshore by the sea breeze and prevailing winds.

Based on field observations, it is likely that the timing of the disappearance of the marine layer and the onset of morning winds within a few hours after the marine layer breaks down are important to beach tar. As noted in Section 2.6.4, oil is observed to sink within a few hours after the marine layer lifts and photolysis begins. Although diurnally-averaged winds are weaker in the summer than winter (Figure 28), the key afternoon sea breeze winds are $\sim 20 \%$ stronger in the summer than winter, with median wind speeds of 


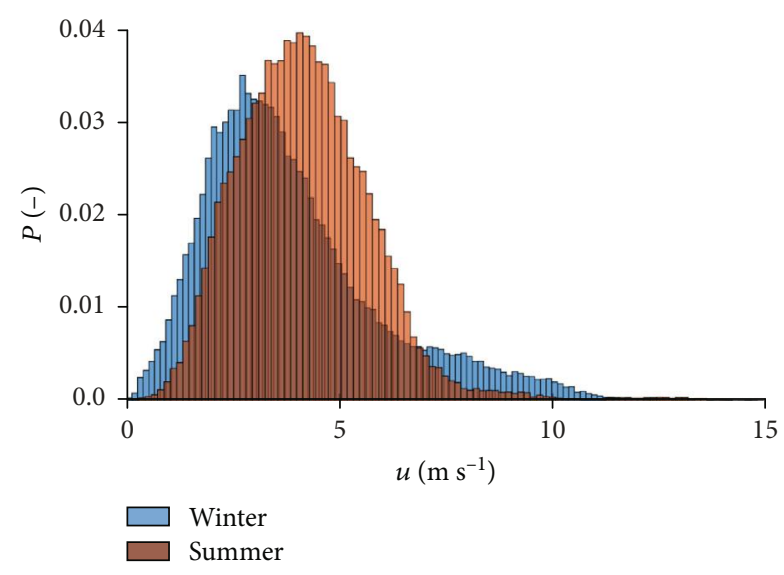

Figure 29: Winter (May-Aug) and summer (Jan-Apr) afternoon $(1200-1800 \mathrm{LT})$ wind speed $(u)$ probability $(P)$ for $1990-2009$ for West Campus Station.

$4.07 \mathrm{~m} \mathrm{~s}^{-1}$ versus $3.44 \mathrm{~m} \mathrm{~s}^{-1}$, for summer versus winter afternoon winds, respectively (Figure 29). Wind distributions are fairly skewed, with higher probability of very strong winter winds (and wave breaking). This suggests strong seasonal nonlinearity in beach tar accumulation with respect to wind speed. Based on the location of the major seeps, oil tends to form multiple oil slick streamers parallel to the coast. Thus, tar arriving at COP from further offshore oil streamers is more likely to suffer significant sinking losses.

The $40 \mathrm{~kg}$ of tar for the study area on 27 Feb. 2005 was exceptional compared to the annual average of $3.49 \mathrm{~kg}$ for the study area, moreso for winter when tar coverage is less. Beach tar coverage was near $75 \%$ from the swash zone to the bluffs and extended with similar coverage at least several kilometers to the west based on a beach survey. If we assume that the tar distribution falls off as a Gaussian with a length scale on the order of $\sim 5 \mathrm{~km}$ (based on the beach survey), there could have been several cubic meters of oil on the beach. Based on Hornafius et al. [40], field emissions of $100 \mathrm{bbl} \mathrm{dy}^{-1}$ and that average beach tar accumulation on 27 Feb. 2005 were ten times higher than average, a conservative estimate of seep field oil emissions for 27 Feb. 2005 of 1,000 bbl day ${ }^{-1}$. This estimate requires typical environmental conditions (which they were). One mechanism that could explain this exceptional increase in emissions, proposed in Del Sontro [190], was aquifer recharge by the exceptional rainstorm a few days prior (Figure 19). The resulting increase in pressure in the reservoir or in migration pathways that intercept onshore aquifers may have created new migration pathways or blown clear oil and tar (seals) clogging existing pathways.

A more extensive beach tar dataset spanning 2005-2011 than just the 2005 data that was available to Del Sontro et al. [189] was analyzed and provided improved resolution of seasonal trends (Figure 30). Tar accumulation showed three peaks, a spring peak (March-April), a weak, midsummer peak (June-July), and a much larger early fall peak (September). The spring and summer peaks include sharp increases followed by steady declines, whereas the fall peak rises slowly and then drops rapidly. Average daily winds are close to constant from June through September, decreasing slightly afterwards (Figures 17(d) and 28) and thus cannot explain the seasonal peaks. Meanwhile, swell increases in September and again in October (Figure 28). From March to April, swell is greater and winds are stronger due to storms, correlating with the spring peak. Swell does not affect oil transport; however, swell affects seep gas emissions [49]. Given that gas and oil emission rates are interrelated for the same seep vent [115] and interconnected vents [112], swell likely affects oil emissions. Additionally, Leifer and Wilson [115] showed that tidal pressure changes affects both oil and gas emissions; thus, swell pressure variations affect both gas and oil.

If oil emission rates relate to swell, then low-swell periods correspond to periods of low emissions during which migration pathways likely become clogged, i.e., self-seal, as discussed in Hovland [105]. These reduced permeability pathways allow subsurface oil accumulation in near-seabed reservoirs that is released with the onset of strong swell in fall. As migration pathways reopen, or new ones are formed, tar and oil buildups are driven out as oil slugs, a process documented by Leifer and Wilson [115], on hour timescales for anthropogenic seepage off Summerland. This depressurizes the near-seabed reservoir, with oil recharge from deeper occurring slower than for gas. Supporting this hypothesis is the increase in seep gas emissions in August/September after the lengthy period of low summer emissions (Figure 17). Given that swell is fairly constant all summer, the midsummer peak likely relates to transport processes including weaker nocturnal winds and stronger afternoon winds (sea breeze) and factors including the prevalence of the marine cloud layer. The largest storms and swell of the year are in the spring when there also is a peak in beach tar accumulation. The spring peak could be smaller than the fall peak due to the continuously stronger winter swell reducing subsurface oil accumulation by driving above-average oil emissions, i.e., less oil accumulated for spring release. Data are too sparse to develop hypotheses as to why the fall peak decrease is so much faster than the decrease of the other peaks.

Although individual surveys showed no clear wind speedtar accumulation relationship, monthly averaged data show a clearly increasing trend to $\sim 3 \mathrm{~ms}^{-1}$, above which tar mass appears to be either unrelated to wind speed or slightly negative (Figure 30(c)). This would be consistent with a transport pattern that for wind speeds faster than $3 \mathrm{~m} \mathrm{~s}^{-1}$, the transport time to the beach is shorter than typical weathering and sinking timescales. At higher wind speeds (Figure 29), wave breaking and dispersion losses are greater.

2.6.4. Spatial Variability of COP Beach Tar. Due to longshore current and the beach configuration around COP, Devereaux Beach to the east of COP is far broader than Sands Beach to the west (Figure 27). In general, tar is stranded primarily at the upper reach of the last high tide's swash zone [178] and the upper reach of the swash zone at the time of the survey [189]. Transect 7 is located immediately east of COP, which features rock outcroppings with the highest tar accumulation of $\sim 55 \mathrm{~m}$ from the bluffs where the outcroppings protect the beach, rather than towards the bluffs. Daily total tar mass accumulation on Sands Beach $(290 \mathrm{~g} / 120 \mathrm{~m})$, west of COP, is less than on Devereaux Beach $(590 \mathrm{~g} / 120 \mathrm{~m})$, east of COP 


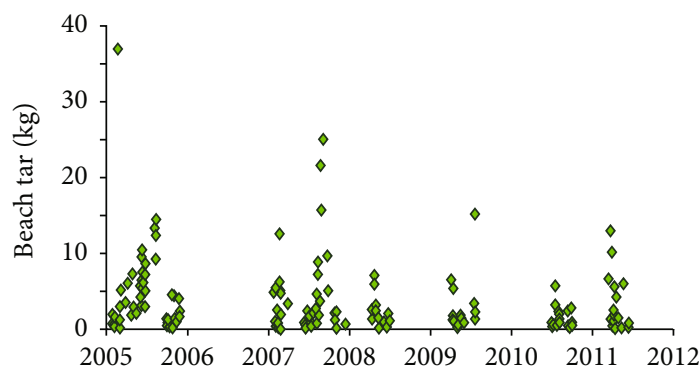

(a)

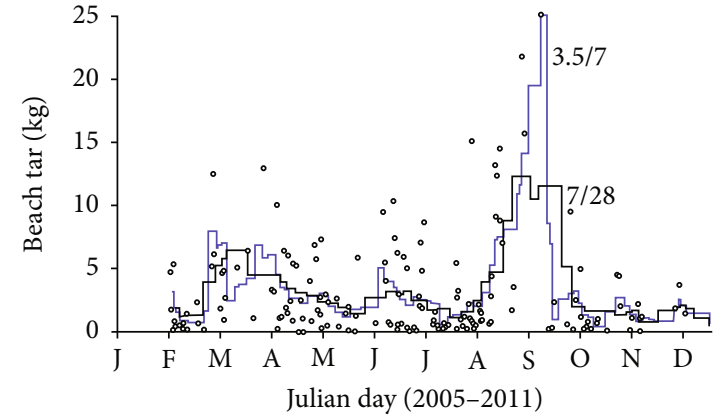

(b)

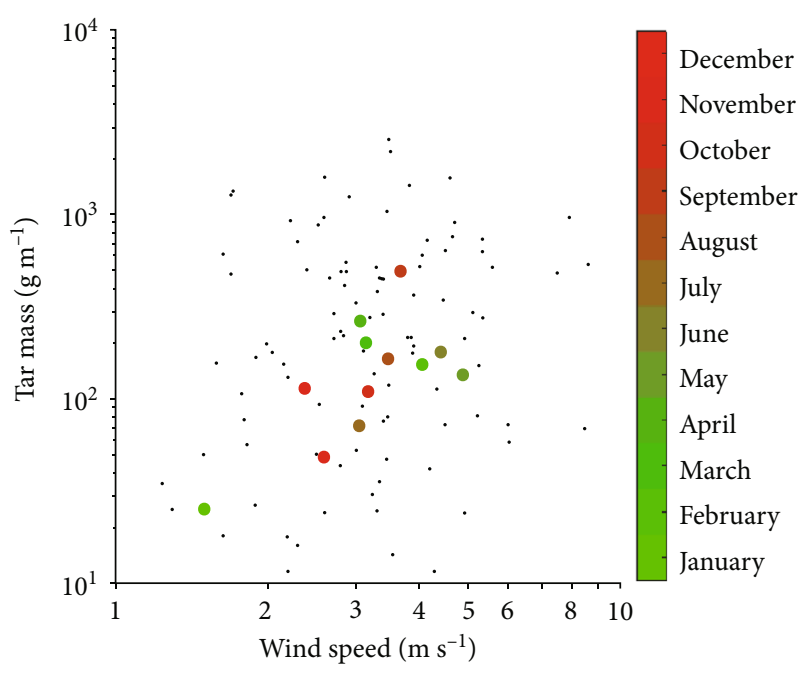

(c)

Figure 30: (a) Total beach tar accumulation for the Coal Oil Point study area. (b) Study area tar accumulation versus Julian day with 28-day smoothing with 75\% overlap (7/28) and 7-day smoothing with 50\% overlap (3.5/7), respectively. Low data density in late December-January reflects poor student availability. (c) Beach tar accumulation versus wind speed for individual and monthly averaged surveys.

(Figure 31). This asymmetry reflects longshore current differences across COP and tar arrival from the westsouthwest. Specifically, COP protects Devereaux Beach, leading to much lower wave energy and slower longshore transport. This deceleration in the longshore current increases sand (and tar) accumulation on Devereaux Beach. Tar buildup is nonuniform with distance from the bluffs, largely accumulating preferentially on the upper beach, i.e., the last high tide mark, which also is most strongly influenced by storms. For the lower beach, tar accumulation is greater on Sands Beach than on Devereaux Beach, $78 \mathrm{~g} / 80 \mathrm{~m}$ versus $53 \mathrm{~g} / 80 \mathrm{~m}$, respectively, with Transects 6 and 7 classified as outliers due to low tide outcropping at COP. The lower beach distribution on both beaches decreases monotonically towards COP from peaks at $\sim 50 \mathrm{~m}$ distant from COP (Transects 2 and 11 ), i.e., a length scale comparable to the beach width.

Under high swell, sand accumulates on the beach, whereas under low swell, the beach loses sand. Thus, under high swell, which affects the upper beach, waves increase tar accumulation on Sands Beach, with even higher tar accumulation on upper Devereaux beach due to deceleration of the longshore current as it rounds COP (Figure 31). The lower beach reflects the arrival and removal of tar in the swash zone (including the longshore current), with the decrease towards COP consistent with rip current outflows from COP (e.g., Figure 23), driven by the sharp gradients in wave stress and longshore currents [184] across COP. This highlights a mechanism by which swell affects tar accumulation by increasing the residence time of tar in the swash zone as it migrates under the longshore current. Under lower swell (summer), down-beach (east) tar migration along the beach in the swash zone (including at high tide) is slower and accumulation is larger. Given that the longshore current varies roughly linearly with swell height [186], lower summer swell should enhance summer tar accumulation over winter by a factor of $\sim 2$. This is less than the factor of 3 reported in Del Sontro et al. [189]; thus, other factors, such as seasonality in oil emissions and factors associated with transport to the beach, also likely play a role.

Wave-breaking turbulence in the surf zone strongly modifies the tar ball size distribution depending on the oil's physical characteristics. Greater wave height leads to more energetic wave breaking on the beach, which fragments tar balls into smaller tar balls. Del Sontro et al. [189] found an inverse correlation between tar ball size and wave height. This is shown by a map of the ratio $(R)$ of tar mass in small (classes 


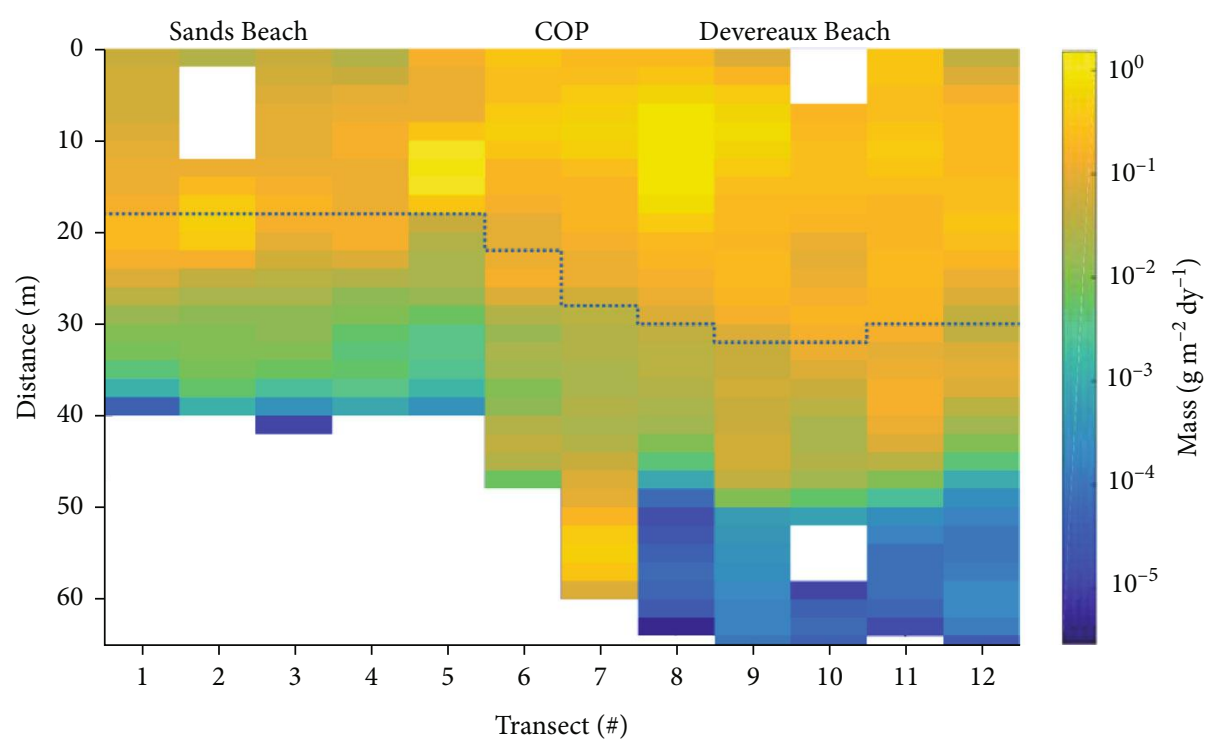

(a)

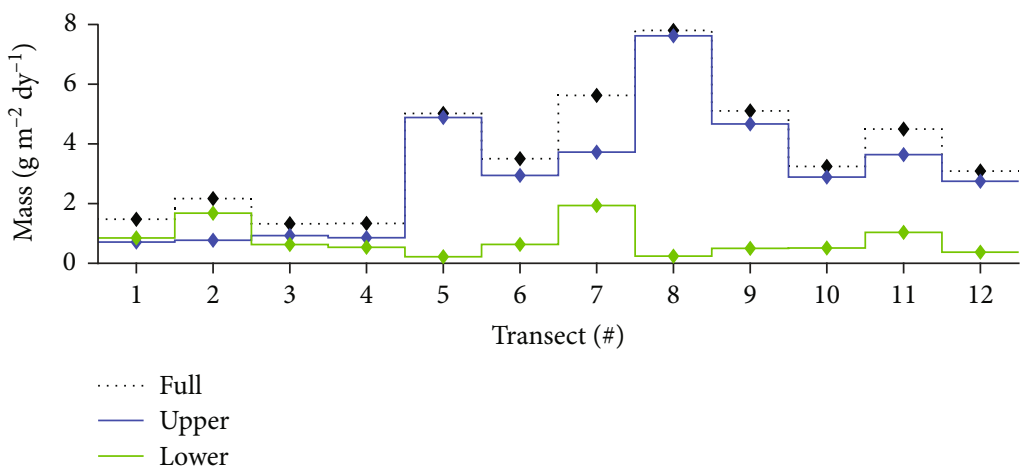

(b)

Figure 31: (a) Daily mean tar mass, 2007-2009, for Coal Oil Point (COP), versus distance from the bluffs and transect. Tar mass was $4 \mathrm{~m}$ smoothed along the distance axis. Dotted line shows midbeach point. (b) Aggregated tar mass, integrated along the distance axis for the full beach and upper and lower halves.

1 and 2) to large (classes 3 and 4) tar balls (Figure 32). Smaller tar balls were heavily focused at the swash zone, with larger tar balls focused at the high tide level. The mean $R$ for Sands Beach (neglecting tar-free quadrats) was $2.09, \sim 7 \%$ greater than that for Devereaux Beach to the east (1.95), a slight emphasis of smaller tar balls to the west. The small difference likely relates to longshore transport and greater wave energy.

Tar is unevenly distributed across the beach, tending to be stranded in tar aggregates. A total of 1,119 beach tar aggregations were identified for the 12 transects for 2007-2009. The tar aggregate probability distribution (Figure 33) was highly skewed, with mean and median aggregate mass $\left(M_{A}\right)$ of 12 and $1.6 \mathrm{~g} \mathrm{~m}^{-1}$, respectively. The maximum $M_{A}$ was $475 \mathrm{~g} \mathrm{~m}^{-1}$ with area coverage as high as $45 \%$ for a $2 \times 2$ quadrat.

Three different probability regimes were identified in the beach $M_{A}$ occurrence distribution $\left(P\left(M_{A}\right)\right.$, Figure 33) to compare the distribution of different size aggregates along the beach. One regime was for $M_{A}<\sim 10 \mathrm{~g} \mathrm{~m}^{-1}$ and was very weakly dependent on $M_{A}$. A second regime was for $10<$ $M_{A}<100 \mathrm{~g} \mathrm{~m}^{-1}$, which decreased with a power law exponent of -0.71 , and a third regime was for $M_{A}>100 \mathrm{~g} \mathrm{~m}^{-1}$ with a power law exponent of -2.27 for the largest aggregations. For very low $M_{A}\left(<10 \mathrm{~g} \mathrm{~m}^{-1}\right), P$ falls off rapidly. Correlation coefficients for the two higher $M_{A}$ populations (unsmoothed) are good, 0.84 and 0.86 , respectively.

$P\left(M_{A}\right)$ for these different mass regimes varied with transect (Figure 34), following a similar trend to the location of tar (Figure 31) with more aggregates on Devereaux Beach than Sand Beach. For the largest $M_{A}$ aggregates, the peak was located immediately to the east of COP (Transect 8), suggesting that recirculation flows associated with the outcropping in the longshore current direction played a role. In contrast, the smallest aggregates $\left(M_{A}<10 \mathrm{~g} \mathrm{~m}^{-1}\right)$ are far more evenly distributed, with peak around Transect 7 . There is an inverse correlation between the trend in the occurrence of the smallest and largest aggregates around COP for Transects 7-10, supporting the potential importance of tar 


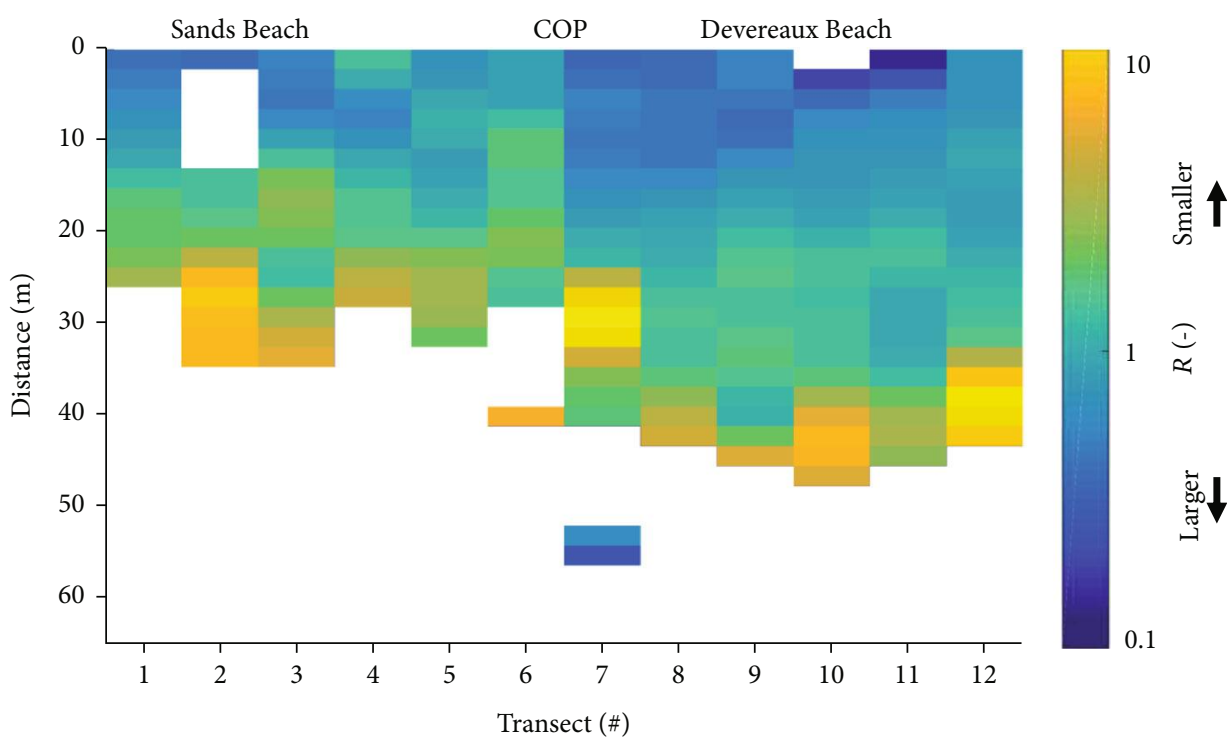

Figure 32: Tar mass accumulation ratio $(R)$ of small (classes 1 and 2$)$ to large (classes 3 and 4$)$ tar balls $(R=\operatorname{mass}(1 \& 2) /$ mass $(3 \& 4))$, 20072009 for Coal Oil Point (COP), with respect to distance from the bluffs and transect. $R$ was $4 \mathrm{~m}$ smoothed along the distance axis.

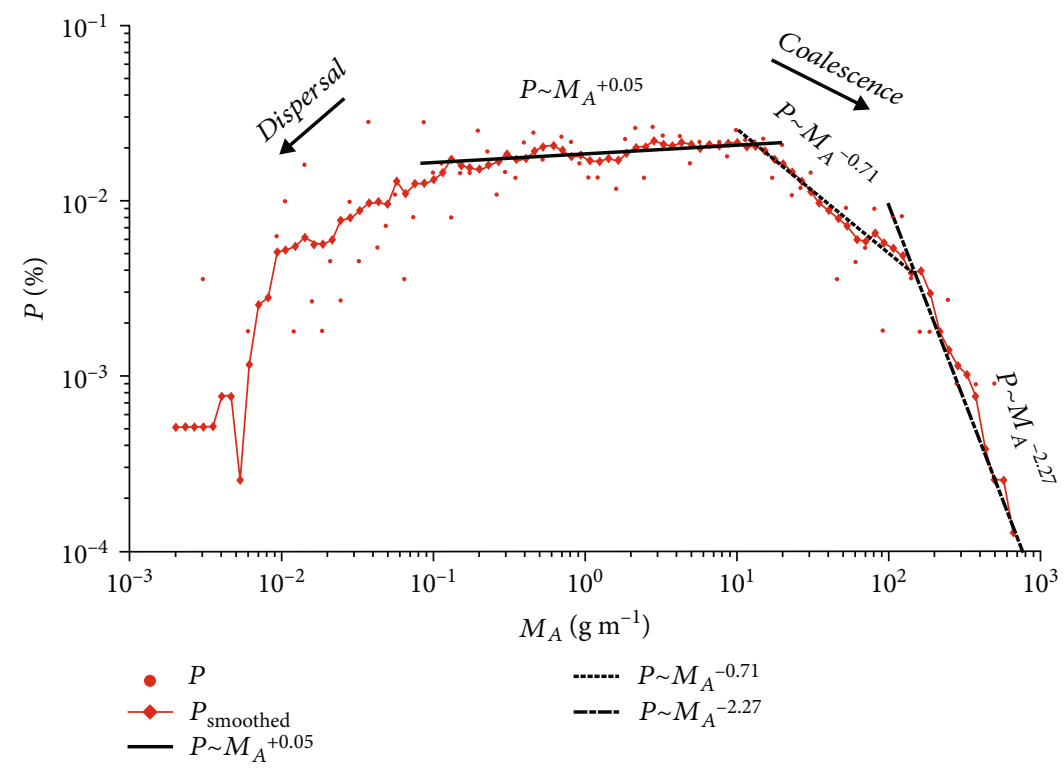

FIGURE 33: Tar aggregate mass $\left(M_{A}\right)$ versus unsmoothed and 7-point smoothed probability $(P)$, and least-squares linear regression analysis power law piecewise fits. Data key on the figure.

aggregation coalescence in the swash zone, i.e., the flow field is nondispersive, allowing growth of larger aggregates at the expense of smaller aggregates. The probability distribution of the ratios of smaller (classes 1 and 2) to larger (classes 3 and 4) tar balls for these three regimes are very similar, showing that the factor determining tar aggregation size is at most weakly related to wave energy but primarily due to the swash zone flow field associated with COP.

The aggregate mass probability distribution (Figure 33) is reminiscent of that for aerosols, where small aerosols may evaporate, shrinking while larger aerosols grow and coalesce.
By analogy, fluid motions that either disperse or coalesce floating oil seem to be the dominant underlying process controlling tar aggregate formation size.

2.7. Offshore Long-Term Fate of Seep Oil. Buried tar is not found on beaches around COP [189], i.e., wave energy is sufficient to remove stranded tar balls at the next high tide. This is in contrast to the Gulf Coast where removal of centimeter-size tar balls that have incorporated sand is challenged even by storms [188]. Underlying this are steeper beaches and greater wave energy for California. 


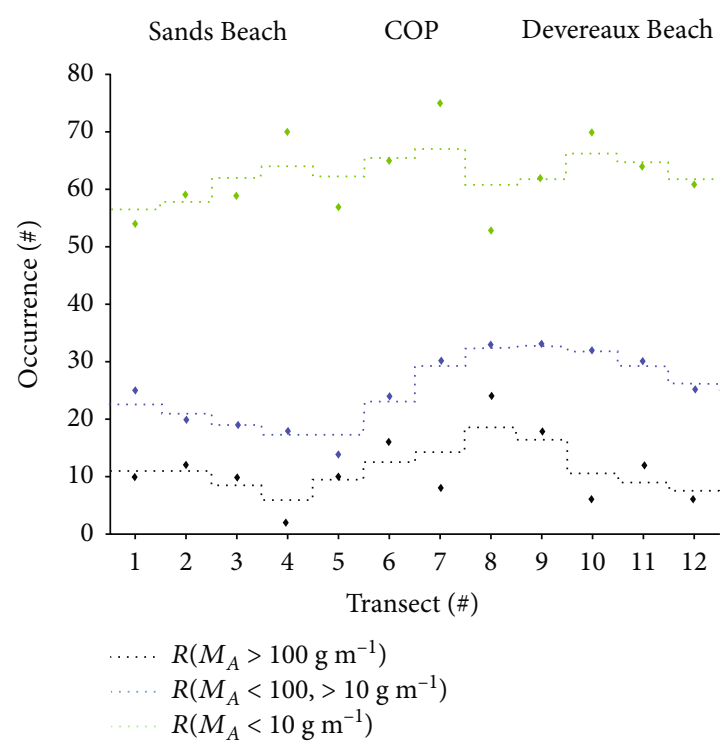

(a)

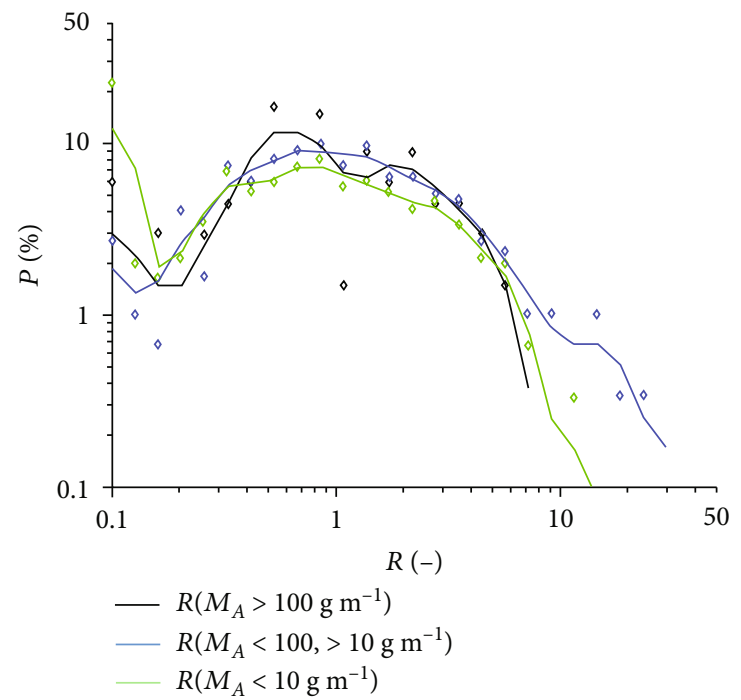

(b)

FIGURE 34: (a) Occurrence of tar aggregate in three aggregate mass $\left(M_{A}\right)$ regimes versus transect number, nearest neighbour smoothed (line) and unsmoothed (symbol). (b) Probability $(P)$ of tar mass accumulation ratio $(R)$ defined as (tar ball sizes 1 \& 2 )/(tar ball sizes $3 \& 4)$ for three aggregate mass regimes nearest neighbour smoothed (line) and unsmoothed (symbol). Data key on figure.

Del Sontro [190] showed that tar was stranded at the highest swash line by the ebbing tide until the next tide reached the same point on the beach, generally 1-3 days depending on tides. This is likewise similar to the 1-2-day residence time noted by Hartman and Hammond [191].

Beach-stranded tar weathers faster than floating oil due to warmer sand temperature for the same solar insolation. Weathering increases its density, as does incorporation of sand into its matrix, rendering it less buoyant. Note that buoyancy can be increased by incorporation of vegetative material such as kelp, often found in berms on beaches during storms.

Upon retrieval by the next flood tide, the weathered tar likely rolls along the seabed or drifts and bobs above the seabed in a sufficiently energetic wave field, rather than floating at the sea surface. In the surf zone, the near-seabed current is offshore and will transport tar towards the shoaling zone, beyond which near-seabed currents are onshore. Here, the longshore current transports submerged oil towards the east.

For typical Santa Barbara summer waves $(\sim 0.5 \mathrm{~m}$ height, $\sim 7$-second period) impinging at $15^{\circ}$ to a $3^{\circ}$ sloped beach, the longshore current is $1.2 \mathrm{~m} \mathrm{~s}^{-1}$ or $50 \mathrm{~km}$ per tidal cycle based on a simple empirical model of Harrison [186]. However, the longshore current decreases away from the swash zone, by around a factor of four based on the field data of Kraus et al. [245]; thus, longshore transport could be $\sim 10 \mathrm{~km}^{\text {day }}{ }^{-1}$.

More sophisticated treatments of longshore current have been developed; however, their application requires numerous beach and oceanography and meteorology parameters that are largely unknown. Beach parameters are highly dependent on oceanography and orientation and are continuously changing, due in part to sand removal during winter storms and buildup in the summer. Additionally, these models are for sand transport, yet tar is not sand, and thus its longshore transport is likely different from that of sand. For example, transport occurs beyond the swash zone although where and at what height above the seabed (and hence velocity relative to sand transport velocities) remain unknown.

The ultimate fate of beach tar is unclear-while on the beach, tar clearly weathers-losing volatiles (becoming less pungent) and less deformable (or more brittle) and incorporating sand into its matrix. This ensures that after removal from the beach with the next high tide, the tar balls travel as submerged oil, likely along the seabed and/or becoming buried in nearshore sediments. Nearshore offshore sediment burial is unlikely to be permanent-seasonal winter storms tend to transport sand from area beaches to deeper waters.

Rip currents are observed offshore of COP (Figure 23) that would transport sand and tar beyond the shoaling zone. These currents maintain the seabed ridge extending south of COP sand free, transporting sand and tar into the Davidson Current, which heads more westerly than surface currents. Rip currents also are likely from other coastal points, such as Campus Point.

2.8. COP Seep Ecosystem. The utilization by chemosynthetic microbial communities of seep $\mathrm{CH}_{4}$ and higher hydrocarbons in waters from the deep sea to shallow coastal is well documented [2]. These microbes include methanotrophs, which oxidize $\mathrm{CH}_{4}$, and thiotrophs, which oxidize sulfide [64]. In the deep sea, chemosynthetic energy overwhelms (locally) energy derived from the photic zone. In shallower water, nonchemosynthetic specialist organisms from the local marine ecosystem generally outcompete seep-specialist organisms [67] although typical seep species are found at strong shallow seeps [81]. Thus, shallow (photic-zone) seep-associated ecosystems can utilize energy from both chemosynthetic and photic sources [71] and terrestrial- 
sourced material in the case of coastal seepage. Leifer et al. [71] argue that whereas both oil and gas provide bioavailable chemosynthetic energy, oil's toxicity provides advantages to tolerant species. As a result, seeps are oases for infaunal species with high population density compared to the surrounding seabed, albeit at reduced species diversity $[69,75,82]$.

Compared to the numerous deep sea ecosystem studies, few studies have investigated shallow photic-zone $\mathrm{CH}_{4}$ seep ecosystems (beyond the microbial community structure), even less involving oil and gas seepage. Most of these studies have been for the COP seep field, where seep emissions have occurred over geologic timescales [192], i.e., long enough for evolutionary adaptation. Such adaptations have been identified in some marine fauna, e.g., sea urchins [246], but largely remain unstudied for shallow seeps.

COP oil and gas seep hydrocarbons provide bioavailable chemosynthetic energy that enters the shallow water food chain through microbial oxidation [71]. Despite toxicity in seep hydrocarbons, macro infaunal densities and diversity were higher at the Isla Vista Super Seep [225] than at a comparison site outside the seeps in all seasons over a three year span 1975-1978 [83]. Spies and Davis [225] reported 135 benthic species at the seep in June. Although, currently, Isla Vista Super Seep is purely gas, in the late 1970s [225], 1980s [247], and early 1990s [248], it was oily, releasing oil droplets. Davis and Spies [83] found the highest population in August, matching the August-September peak in beach tar (Figure 30).

Thick Beggiatoa bacterial matts are common at seeps in the COP seep field and appear to be a food source for invertebrates [249]. Specifically, stable carbon isotope ratios in invertebrate tissues indicated petroleum carbon uptake into the benthic community by microbial decomposition. This energy transfer was from chemoautotrophic sulfide oxidizers (Beggiatoa spp.) to nematodes, polychaetes, and other infaunal organisms [249]. Rates of seep microbial sulfate reduction and hydrocarbon (oil) degradation are greater in the center of active seepage than at the edge of the Isla Vista Super Seep [247], indicating carbon cycling scales with emissions. In this study, Montagna et al. [247] measured microbial degradation of hexadecane, naphthalene, and anthracene. At higher trophic levels, a comparison of two different fish species ( $\mathrm{Hyp}$ surus caryi and Rachochilus toxodes) from the Isla Vista Super Seep area and a reference area showed elevated petroleum hydrocarbons in the benthic feeding species at the seep [248]. These fish species feed extensively on small crustaceans. Greater sublethal effects were observed in individuals of the species from the seep, particularly the benthic feeding $H$. caryi, than reference site individuals.

Studies for the COP seep field have investigated the spatial distribution of community structure in relation to chemical gradients and identified significant complexity. However, the reality is far more complicated as seepage is highly variable on a range of time and spatial scales (Section 2.4). This variability can be slow and lead to slow evolution of the community richness, diversity, and abundance, for example, following seasonal trends (Section 2.4.5), e.g., Davis and Spies [83]. Alternatively, variability can be abrupt (Section 2.4.4) either from large transient increases in chemical stressors (eruptions) or from disappearance of chemosynthetic energy and its stressors, or by a combination of both through seep relocation as migration shifts from one pathway to another. Abrupt emissions drive a community disturbance, followed by colonization by more aggressive species and then a series of succession stages as predation by higher trophic levels takes advantage of the chemosynthetic energy, nutrients are depleted, and other stressors affect the community. Note that diversity can increase even as biomass decreases due to waning seep emissions after a transient release or initiation of new seepage in an area. These processes have been studied for deep sea seepage in the Gulf of Mexico [250] and elsewhere [3]; however, studies for shallow seeps (including the COP seep field) in general are lacking.

In general, most studies of the interaction of marine oil and the shallow marine ecosystem (outside microbial levels) have been from oil spills, which generally introduce petroleum hydrocarbons abruptly raising local concentrations to well above ambient petroleum (polycyclic aromatic hydrocarbons (PAHs)) levels, which includes pollution from industrial and transportation sources as well as natural PAHs [251, 252]. Thus, oil spills are a proxy for eruptive rather than normal seep emissions, although chronic spills exist, such as in the Persian Gulf [253], and would be a proxy for noneruptive seepage.

Beyond the immediate lethal and sublethal effects of petroleum hydrocarbon toxicity from a spill or natural seep eruption, there are rapid shifts in species composition towards species that are more tolerant of petroleum toxicity and/or with less sensitive feeding strategies and a decrease in species abundance and diversity [254]. This has highly significant and long-term ecosystem implications across the food web as the shifts in community composition affect food availability for some species [255].

For ecosystem settings where petroleum hydrocarbon seepage has occurred on geological timescales, such as the COP seep field, ecosystem adaptation occurs at all levels. This leads to higher species diversity and abundance [83] in part due to the greater diversity of ecological niches [3]. Moreover, the presence of chemosynthetic energy sources provides a bioavailable energy source that can be utilized by higher trophic levels during seasons and conditions of nutrient limitation. This has been proposed to contribute to higher biological productivity in waters with active seepage $[63,71]$.

\section{Knowledge Gaps and Research Needs}

3.1. Overview. In 2003, a seepage workshop was held to identify major knowledge gaps in our understanding of seep processes and key research needs [256]. Knowledge gaps were identified in mechanisms of control of migration and seepage and on fate with respect to how seep energy percolates up the food chain. At the time, most studies reported the presence of seepage with few quantitative studies on emissions or characterization of processes that affect the seep hydrocarbon's fate.

Since, techniques to quantitatively map seep emissions have been applied to seep fields across the world's oceans. In several areas, particularly the COP seep field, studies have related geologic controls to seep flux (prior studies had 
related geology with seep presence/absence). Additionally, new measurements and numerical bubble model studies have improved understanding of the fate of seep methane and other trace gases across the water column in the COP seep field and elsewhere. Furthermore, significant insights have been made in understanding how seepage enters the food chain at the microbial level, although our understanding of the role of seep hydrocarbons, particularly oil, to higher tropic levels remains poor. Equally important, little is known for seepage as a chemosynthetic energy source to the food chain in the photic zone.

Quantitative seep emission studies have documented high variability, implying significant uncertainty in extrapolating from short campaign measurements to annualized emissions. Underlying this uncertainty is a lack of understanding of the factors driving variability including eruptive emissions. It also should be noted that although quantitative emissions are available for a dozen or so seep areas around the globe, most areas globally where seepage is feasible remain uninvestigated and/or uncharacterized.

Although the bubble processes controlling the fate of nonoily gas seepage are reasonably well characterized, the effect of oil coatings on bubble processes remains largely unknown. Once the oil surfaces, its drift and evolution are well studied based on decades of research into surface oil spills; however, investigation of subsurface oil transport after it sinks remains a poorly understood area.

3.2. Seep Emissions. Bubble size distributions and gas emissions have been assessed for individual seep vents, for major areas of active seepage, and for the entire COP seep field $[39-41,226]$. The fate of seep gas depends strongly on bubble size; yet, the factors affecting this size remain unclear-Leifer and Culling [124] showed in lab studies a dependency on grain size and flow rate. Other processes certainly are important, such as oiliness and bacterial cementing of grains. Currently, field data are lacking in the COP seep field and elsewhere that relate sediment characteristics at the vent orifice with the bubble size distribution.

Recommendation: field studies should assess seabed sediments to understand the controlling factors of seep bubble size distribution and how it changes over the lifetime of a seep vent, facilitating extension of results from one seep field to another.

To date, seep emission measurements have been of noneruptive emissions; thus, our knowledge of eruptive emissions, e.g., Leifer and Boles [114] and Leifer et al. [130], is poor to nonexistent. Fluid motions associated with transient emissions are unlikely the same as steady state plumes and bubble size distributions are unknown for eruptive emissions; thus, little is known about the fate of these transient events. Due to the infrequency of eruptive events, observations require long-term observations such as from benthic observatories.

Recommendation: field studies should include benthic observatories and be integrated with studies to understand how the fate of eruptive emissions differs from steady-state emissions.

Although a range of measurement tools for gas seepage quantification are available and have been used in the COP seep field and elsewhere, seep oil quantification is largely absent from the literature. Tools are needed, with remote sensing showing promise [257]; however, it remains largely untapped for estimating seep oil emissions, MacDonald et al. [58] being a notable recent exception. Absent approaches to quantify oil emissions, our understanding of eruptive and continuous seep oil emissions remains largely anecdotal. Yet, given the role of oil in the sealing of migration pathways and its higher viscosity, oil emissions are likely more eruptive than gas emissions.

Recommendation: remote sensing approaches available for oil spill remote sensing should be adapted to assess quantitatively seep oil emissions. Further field data on oily bubbles are needed that characterize the factors controlling oiliness of different size bubbles in the plume. New, validated, underwater remote sensing methods are needed, such as high fidelity multibeam sonar, for characterizing and quantifying oil and oily bubble emissions.

3.3. Geological and Other Controls on Seepage. Although studies long have investigated geological controls on the spatial occurrence of seepage [96], few have investigated seep strength with respect to geological controls; e.g., Leifer et al. [102] showed fine-scale $(<100 \mathrm{~m})$ spatial control of emissions by geological structures (Figure 12), and Leifer et al. [38] showed quantitative multibeam sonar emission data that were proposed related to near-surface geological controls on a meter to $10 \mathrm{~m}$ scales in both the COP seep field and the Arctic. Bradley et al. [53] showed geological controls on trends in the spatial seepage emission distribution-proposed related to vent activation and deactivation based on overpressure and permeability. These processes are described in the seep electrical model (Figure 3), which implies, among other things, that seep field emissions should "ring" with preferred time periods to forcing. New technologies, such as rotating multibeam sonar scanners in benthic observatories $[32,117]$, will collect the $4 \mathrm{D}$ data needed to detangle spatial and temporal variability and controlling processes. On larger time and spatial scales, the unique long-term COP seep field data (Figure 18) spanning 60 years provides an opportunity to investigate long-term variability and processes.

Recommendation: whether through repeat multibeam sonar surveys or rotating multibeam sonar benthic observatories, quantitative $4 \mathrm{D}$ data are needed to relate temporal emission trends to shallow and deep geological structures. The COP seep field can continue to play a key role in developing insights due to its diverse types of seepage and sediment from bare rock to sandy, nonoily to oily, single bubble to megaplumes and its unique multidecadal data. Such data should be used to test hypothesized processes by numerical models, such as a numerical seep electrical model.

3.4. Chemical and Physical Fate(s) of Seep Hydrocarbons. Although understanding of the primary mechanisms driving the water column fate of seep field gas emissions is well studied and understood for shallow seepage, significant uncertainty remains with respect to the importance of hydrates-particularly Type 2 hydrates [122]-and 
other deep-sea processes like pressure-dependent solubility for multiple gas mixtures. Type 2 hydrates are relevant for thermogenic seepage that is not pure $\mathrm{CH}_{4}$. Unlike gas bubble processes, the effects of oil coatings on bubble processes remain unknown-oil slows bubble rise velocity and gas exchange and likely affects other bubble processes, such as particle absorption and transport, and hydrate bubble skins.

Recommendation: laboratory studies of oily bubbles for a range of oiliness and oil types and bubble sizes are critically needed to provide parameterizations for numerical bubble models. Additional field data are needed to validate parameterizations and numerical bubble models.

Subsurface oil transport from both COP seep field slicks and after remobilization from area beaches is critical to understanding the fate and impacts of oil from the COP seep field (and other coastal oil seeps). Although validation efforts of oil slick trajectory and weathering models demonstrate significant uncertainties in the underlying processes, at least there are parameterizations for most processes (except perhaps photooxidation, which at least for COP seep field oil slicks plays an important role). In contrast, there are few field studies that shed light on how oil and tar drift and evolve subsurface, particularly in the complex nearshore environment. In part, this is from a paucity of measurement tools. In contrast, quantitative and semiquantitative oil thickness remote sensing approaches are becoming available and can provide important oil slick process validation data.

Recommendation: natural oil seepage provides an invaluable natural laboratory with no release permissions required. Natural seep oil slicks should be studied to improve understanding of oil slick processes at the sea surface and floating oil subsurface. Field studies should leverage and develop the latest remote sensing approaches both airborne and vessel borne, including multibeam sonar. Furthermore, field and lab photooxidation studies are needed.

3.5. Biological Fate(s) of Seep Oil and Gas. There are large gaps in our knowledge on how seep hydrocarbons move through the food chain above the microbial level $[3,71]$, how the community structure (benthic, epibenthic, meiofaunal, and megafaunal) varies between seep-specialist organisms and nonspecialist organisms with respect to seep indicators (chemical indices, fluid flows, presence of bubbles, and substrate), and how species that predate on both seep and non-seep-specialists "chose" between chemosynthetic and non-chemosynthetic sources. This is particularly significant given that chronic exposure can lead to sublethal health problems [248] and negative evolutionary pressures.

Recent studies have investigated the flow of chemosynthetic energy to higher trophic levels, including top predators, although most aspects remain uncharacterized. Leifer et al. [71] proposed that chemosynthetic energy could also play important roles during seasons of nutrient or light limitations. Seasonality was noted in community abundance in Davis and Spies [83]; however, mechanisms and most details remain unknown. Seep systems are highly variable on a range of timescales including eruptive emissions. Thus, temporal variability likely plays important roles in seep ecosystems.
Recommendation: since the COP seep ecosystem studies in the 1970s [249], isotopic and genetic approaches have become available that also can connect to sublethal impacts on species [248]. Modern ecosystem impact studies are needed. Additionally, seep ecosystem studies should be part of benthic observatory long-term data collection to address succession and adaptation to transient and gradual variations in emissions.

3.6. California Seepage. Most California seep research has focused on the COP seep field for reasons including proximity to Santa Barbara, protection against waves and wind (compared to seepage near Point Conception), size, and shallowness and thus diver accessibility (i.e., at a low cost compared to ROV or submersible depth seepage); however, marine seepage is widespread in coastal southern and central California waters $[125,138]$, with geologic basin data suggesting that northern California waters also likely feature seepage. Our current understanding of the distribution of California marine seepage on basin and regional scales is at best poor, and processes identified for the COP seep field remain largely unverified for California marine seepage elsewhere.

In the case of riverine seepage, almost nothing is known [208], even though California streambeds and riverbeds generally follow faults and thus have enhanced seepage occurrence probability.

Marine hydrocarbon seepage extends along much of the southern and central California coasts and likely further north, albeit largely uncharacterized and/or undiscovered. Thus, "pristine" reference sites free from seepage along the southern California coast do not exist. Ecosystem impacts of the COP seep field decrease with downstream distance while impacts from other seep fields, such as the Point Conception seep field, increase. Little is known about how impacts transition between seep fields. Schmale et al. [70] showed that bubbles are efficient at transporting chemotrophs into the water column and to the sea surface. Deposited, lofted bacteria drift downstream, likely "inoculating other seep areas," and thus allow microbial and higher trophic levels of different neighboring seep fields to interact.

The COP seep field is far from industrial and urban areas and extremely strong; thus, its waters are dominated by its seep PAHs. However, other seep areas, particularly near Los Angeles, are much smaller, and in waters with significant PAH inputs from pollution as well as other nearby seep sources, and natural PAHs from microbial processes. Ecosystem impacts from seepage in these waters could be amplified due to synergies between these environmental stressors or diminished due to evolutionary adaptations. For example, few dolphins were found killed from two major oil spills in the Persian Gulf in 1986 and 1991, whereas repeat dolphin die-offs in other years likely associate with red tide events [253].

Recommendation: studies that extend to beyond the COP seep field are needed to characterize other California seep fields including river seepage. Additionally, comparisons with seep ecosystems close to major urban pollution centers, like Los Angeles, are needed. 


\section{Disclosure}

Views and conclusions in the document are those of the author and should not be interpreted as necessarily representing the official policies either expressed or implied, of the supporting institutions.

\section{Conflicts of Interest}

The author declares that they have no conflicts of interest.

\section{Acknowledgments}

Tar data analysis was supported by the US Geological Survey through a Cooperative Agreement \#M07AP12407 NSL 0603b between the Bureau of Ocean Energy Management Regulation and Enforcement (BOEMRE) and the University of California, Santa Barbara (UCSB). Structural geology analysis was supported by the California State Lands Commission, US Minerals Management Service, US Geological Survey, University of California Energy Institute, California Sea Grant, and Institute of Crustal Studies. I also thank Venoco Inc., Carpinteria, CA, for providing subsurface data and Marc Kamerling, Venoco Inc., for the subsurface geological model. Support for writing was provided by Plains All American Pipeline, LLC.

\section{References}

[1] M. A. Abrams, "Significance of hydrocarbon seepage relative to petroleum generation and entrapment," Marine and Petroleum Geology, vol. 22, no. 4, pp. 457-477, 2005.

[2] A. Judd and M. Hovland, Seabed fluid flow: the impact on geology, biology and the marine environment, Cambridge University Press, Cambridge, UK, 2007.

[3] L. A. Levin, A. R. Baco, D. A. Bowden et al., "Hydrothermal vents and methane seeps: rethinking the sphere of influence," Frontiers in Marine Science, vol. 3, no. 72, 2016.

[4] J. L. Charlou, J. P. Donval, Y. Fouquet, P. Jean-Baptiste, and N. Holm, "Geochemistry of high $\mathrm{H}_{2}$ and $\mathrm{CH}_{4}$ vent fluids issuing from ultramafic rocks at the Rainbow hydrothermal field (36 $14^{\prime}$ N, MAR)," Chemical Geology, vol. 191, no. 4, pp. 345$359,2002$.

[5] ASCE Task Committee on Modeling of Oil Spills, "State-ofthe-art review of modeling transport and fate of oil spills," Journal of Hydraulic Engineering, vol. 122, no. 11, pp. 594609, 1996.

[6] I. Leifer, B. Luyendyk, and K. Broderick, "Tracking an oil slick from multiple natural sources, Coal Oil Point, California," Marine and Petroleum Geology, vol. 23, no. 5, pp. 621630, 2006.

[7] I. R. MacDonald, I. Leifer, R. Sassen, P. Stine, R. Mitchell, and N. Guinasso, "Transfer of hydrocarbons from natural seeps to the water column and atmosphere," Geofluids, vol. 2, no. 2, pp. 95-107, 2002.

[8] J. Thrasher, A. J. Fleet, S. J. Hay, M. Hovland, and S. Düppenbecker, "Understanding geology as the key to using seepage in exploration: the spectrum of seepage styles," in Hydrocarbon Migration and Its Near-Surface Expressions, Volume 66, D. Schumacher and M. A. Abrams, Eds., pp. 223-241, AAPG Memoir, 1996.
[9] M. Cârciumaru, R.-M. Ion, E.-C. Nițu, and R. Ştefănescu, "New evidence of adhesive as hafting material on Middle and Upper Palaeolithic artefacts from Gura Cheii-Râşnov Cave (Romania)," Journal of Archaeological Science, vol. 39, no. 7, pp. 1942-1950, 2012.

[10] Z. R. Beydoun, "Prehistoric, ancient and mediaeval occurrences and uses of hydrocarbons in the Greater Middle East Region," Journal of Petroleum Geology, vol. 20, no. 1, pp. 91-95, 1997.

[11] G. Etiope, G. Papatheodorou, D. Christodoulou, M. Geraga, and P. Favali, "The geological links of the ancient Delphic Oracle (Greece): a reappraisal of natural gas occurrence and origin," Geology, vol. 34, no. 10, pp. 821-824, 2006.

[12] G. Etiope, M. Schoell, and H. Hosgörmez, "Abiotic methane flux from the Chimaera seep and Tekirova ophiolites (Turkey): understanding gas exhalation from low temperature serpentinization and implications for Mars," Earth and Planetary Science Letters, vol. 310, no. 1-2, pp. 96104, 2011.

[13] K. A. Kvenvolden and B. W. Rogers, "Gaia's breath-global methane exhalations," Marine and Petroleum Geology, vol. 22, no. 4, pp. 579-590, 2005.

[14] A. Nissenbaum, "Dead sea asphalts-historical aspects," AAPG Bulletin, vol. 62, no. 5, pp. 837-844, 1978.

[15] K. A. Clark, S. Ikram, and R. P. Evershed, "The significance of petroleum bitumen in ancient Egyptian mummies," Philosophical Transactions of the Royal Society A: Mathematical, Physical and Engineering Sciences, vol. 374, no. 2079, 2016.

[16] J. Rullkötter and A. Nissenbaum, "Dead sea asphalt in Egyptian mummies: molecular evidence," Naturwissenschaften, vol. 75, no. 12, pp. 618-621, 1988.

[17] J. Connan, "Use and trade of bitumen in antiquity and prehistory: molecular archaeology reveals secrets of past civilizations," Philosophical Transactions of the Royal Society of London. Series B: Biological Sciences, vol. 354, no. 1379, pp. 33-50, 1999.

[18] S. F. Hodgson, Onshore oil and gas seeps in California, California Department of Conservation - Division of Oil and Gas, 1987.

[19] K. K. Landes, "Mother nature as an oil polluter," AAPG Bulletin, vol. 57, no. 4, pp. 637-641, 1973.

[20] IPCC, Climate Change 2014: Synthesis Report. Contributions of Working Groups I, II and III to the Fifth Assessment Report of the Intergovernmental Panel on Climate Change, IPCC, 2014.

[21] M. Hovland, A. G. Judd, and R. A. Burke Jr., "The global flux of methane from shallow submarine sediments," Chemosphere, vol. 26, no. 1-4, pp. 559-578, 1993.

[22] IPCC, Working Group 1 Contribution to the IPCC Fifth Assessment Report Climate Change 2013-The Physical Science Basis, International Panel on Climate Change, 2013.

[23] M. Rigby, R. G. Prinn, P. J. Fraser et al., "Renewed growth of atmospheric methane," Geophysical Research Letters, vol. 35, no. 22, article L22805, 2008.

[24] S. Kirschke, P. Bousquet, P. Ciais et al., "Three decades of global methane sources and sinks," Nature Geoscience, vol. 6, no. 10, pp. 813-823, 2013.

[25] M. Saunois, P. Bousquet, B. Poulter et al., "The global methane budget 2000-2012," Earth System Science Data, vol. 8, no. 2, pp. 697-751, 2016. 
[26] P. Ciais, C. Sabine, G. Bala et al., Climate Change 2013: The Physical Science Basis. Contribution of Working Group I to the Fifth Assessment Report of the Intergovernmental Panel on Climate Change, IPCC, 2013.

[27] G. Etiope, K. R. Lassey, R. W. Klusman, and E. Boschi, "Reappraisal of the fossil methane budget and related emission from geologic sources," Geophysical Research Letters, vol. 35, no. 9, article L09307, 2008.

[28] K. R. Lassey, D. C. Lowe, and A. M. Smith, "The atmospheric cycling of radiomethane and the "fossil fraction" of the methane source," Atmospheric Chemistry and Physics, vol. 7, no. 8, pp. 2141-2149, 2007.

[29] G. Etiope, A. Feyzullayev, and C. L. Baciu, "Terrestrial methane seeps and mud volcanoes: a global perspective of gas origin," Marine and Petroleum Geology, vol. 26, no. 3, pp. 333-344, 2009.

[30] A. G. Judd, "Natural seabed gas seeps as sources of atmospheric methane," Environmental Geology, vol. 46, no. 8, pp. 988-996, 2004.

[31] K. A. Kvenvolden, T. D. Lorenson, and W. S. Reeburgh, "Attention turns to naturally occurring methane seepage," EOS, Transactions American Geophysical Union, vol. 82, no. 40, p. 457, 2001.

[32] N. Shakhova, I. Semiletov, I. Leifer et al., "Ebullition and storm-induced methane release from the East Siberian Arctic Shelf," Nature Geoscience, vol. 7, no. 1, pp. 64-70, 2014.

[33] I. Leifer and I. MacDonald, "Dynamics of the gas flux from shallow gas hydrate deposits: interaction between oily hydrate bubbles and the oceanic environment," Earth and Planetary Science Letters, vol. 210, no. 3-4, pp. 411-424, 2003.

[34] S. I. Muyakshin and E. Sauter, "The hydroacoustic method for the quantification of the gas flux from a submersed bubble plume," Oceanology, vol. 50, no. 6, pp. 995-1001, 2010.

[35] E. J. Sauter, S. I. Muyakshin, J.-L. Charlou et al., "Methane discharge from a deep-sea submarine mud volcano into the upper water column by gas hydrate-coated methane bubbles," Earth and Planetary Science Letters, vol. 243, no. 3-4, pp. 354-365, 2006.

[36] I. Leifer, "Seabed bubble flux estimation by calibrated video survey for a large blowout seep in the North Sea," Marine and Petroleum Geology, vol. 68, Part B, pp. 743-752, 2015.

[37] M. Veloso, J. Greinert, J. Mienert, and M. De Batist, “A new methodology for quantifying bubble flow rates in deep water using splitbeam echosounders: examples from the Arctic offshore NW-Svalbard," Limnology and Oceanography: Methods, vol. 13, no. 6, pp. 267-287, 2015.

[38] I. Leifer, D. Chernykh, N. Shakhova, and I. Semiletov, "Sonar gas flux estimation by bubble insonification: application to methane bubble flux from seep areas in the outer Laptev Sea," The Cryosphere, vol. 11, no. 3, pp. 1333-1350, 2017.

[39] I. Leifer, "Characteristics and scaling of bubble plumes from marine hydrocarbon seepage in the Coal Oil Point seep field," Journal of Geophysical Research, vol. 115, no. C11, article C11014, 2010.

[40] J. S. Hornafius, D. Quigley, and B. P. Luyendyk, “The world's most spectacular marine hydrocarbon seeps (Coal Oil Point, Santa Barbara Channel, California): quantification of emissions," Journal of Geophysical Research: Oceans, vol. 104, no. C9, pp. 20703-20711, 1999.

[41] A. M. Padilla, S. Loranger, F. S. Kinnaman, D. L. Valentine, and T. C. Weber, "Modern assessment of natural hydrocarbon gas flux at the Coal Oil Point Seep Field, Santa Barbara,
California," Journal of Geophysical Research: Oceans, vol. 124, no. 4, pp. 2472-2484, 2019.

[42] J. Greinert, D. F. McGinnis, L. Naudts, P. Linke, and M. De Batist, "Atmospheric methane flux from bubbling seeps: spatially extrapolated quantification from a Black Sea shelf area," Journal of Geophysical Research, vol. 115, no. C1, article C01002, 2010.

[43] S. Mau, M. Römer, M. E. Torres et al., "Widespread methane seepage along the continental margin off Svalbard - from Bjørnøya to Kongsfjorden," Scientific Reports, vol. 7, no. 1, article 42997, 2017.

[44] T. C. Weber, L. Mayer, K. Jerram, J. Beaudoin, Y. Rzhanov, and D. Lovalvo, "Acoustic estimates of methane gas flux from the seabed in a $6000 \mathrm{~km}^{2}$ region in the Northern Gulf of Mexico," Geochemistry, Geophysics, Geosystems, vol. 15, no. 5, pp. 1911-1925, 2014.

[45] M. Römer, H. Sahling, T. Pape, G. Bohrmann, and V. Spieß, "Quantification of gas bubble emissions from submarine hydrocarbon seeps at the Makran continental margin (offshore Pakistan)," Journal of Geophysical Research: Oceans, vol. 117, no. C10, article C10015, 2012.

[46] A. V. Borges, W. Champenois, N. Gypens, B. Delille, and J. Harlay, "Massive marine methane emissions from nearshore shallow coastal areas," Scientific Reports, vol. 6, no. 1, article 27908, 2016.

[47] J. F. Clark, L. Washburn, J. S. Hornafius, and B. P. Luyendyk, "Natural marine hydrocarbon seep source of dissolved methane to California coastal waters," Journal Geophysical Research: Oceans, vol. 105, no. C5, pp. 11509-11522, 2000.

[48] S. Mau, D. L. Valentine, J. F. Clark, J. Reed, R. Camilli, and L. Washburn, "Dissolved methane distributions and air-sea flux in the plume of a massive seep field, Coal Oil Point, California," Geophysical Research Letters, vol. 34, no. 22, article L22603, 2007.

[49] I. Leifer and J. Boles, "Turbine tent measurements of marine hydrocarbon seeps on subhourly timescales," Journal of Geophysical Research: Oceans, vol. 110, no. C1, article C01006, 2005.

[50] P. J. Fischer, "Oil and tar seeps, Santa Barbara Basin, California," in California Offshore Gas, Oil and Tar Seeps, D. J. Everitts, R. G. Paul, C. F. Eaton, and E. E. Welday, Eds., pp. 1-62, Sacramento, CA, USA, California State Lands Commission, 1978.

[51] S. M. Wiggins, I. Leifer, P. Linke, and J. A. Hildebrand, "Longterm acoustic monitoring at North Sea well site 22/4b," Marine and Petroleum Geology, vol. 68, Part B, pp. 776-788, 2015.

[52] M. Römer, M. Riedel, M. Scherwath, M. Heesemann, and G. D. Spence, "Tidally controlled gas bubble emissions: a comprehensive study using long-term monitoring data from the NEPTUNE cabled observatory offshore Vancouver Island," Geochemistry, Geophysics Geosystems, vol. 17, no. 9, pp. 3797-3814, 2016.

[53] E. Bradley, I. Leifer, and D. Roberts, "Long-term monitoring of a marine geologic hydrocarbon source by a coastal air pollution station in Southern California," Atmospheric Environment, vol. 44, no. 38, pp. 4973-4981, 2010.

[54] G. Marinaro, G. Etiope, N. L. Bue et al., "Monitoring of a methane-seeping pockmark by cabled benthic observatory (Patras Gulf, Greece)," Geo-Marine Letters, vol. 26, no. 5, pp. 297-302, 2006.

[55] Committee on Oil in the Sea: Inputs, Fates, and Effects, Ocean Studies Board, Marine Board, Transportation Research Board, 
Division on Earth and Life Studies, National Research Council, Oil in the Sea III: Inputs, Fates, and Effects, National Academy of Sciences, Washington, D.C., USA, 2003.

[56] K. A. Kvenvolden and C. K. Cooper, "Natural seepage of crude oil into the marine environment," Geo-Marine Letters, vol. 23, no. 3-4, pp. 140-146, 2003.

[57] A. A. Allen, R. S. Schlueter, and P. G. Mikolaj, "Natural oil seepage at Coal Oil Point, Santa Barbara, California," Science, vol. 170, no. 3961, pp. 974-977, 1970.

[58] I. R. MacDonald, O. Garcia-Pineda, A. Beet et al., "Natural and unnatural oil slicks in the Gulf of Mexico," Journal of Geophysical Research: Oceans, vol. 120, no. 12, pp. 83648380, 2015.

[59] ITOPF, Oil Tanker Spill Statistics 2016, International Tank Owners Pollution Federation Limited, 2016.

[60] B. Lehr, B. Sky, A. Possolo et al., Oil Budget Calculator Deepwater Horizon: A Report to the National Incident Command, NOAA, 2010.

[61] USGS, Deepwater Horizon MC252 Gulf Incident Oil Budget: Government Estimates through August 01 (Day 104), US Geological Survey, 2010.

[62] T. Husain and M. B. Amin, Kuwait Oil Fires: Regional Environmental Perspectives, Pergamon Press, New York, NY, USA, 1995.

[63] M. Hovland, S. Jensen, and C. Fichler, "Methane and minor oil macro-seep systems - their complexity and environmental significance," Marine Geology, vol.332-334,pp. 163-173, 2012.

[64] L. A. Levin, "Ecology of cold seep sediments: interactions of fauna with flow, chemistry and microbes," in Oceanography and Marine Biology: An Annual Review, Volume 43, R. N. Gibson, R. J. A. Atkinson, and J. D. M. Gordon, Eds., pp. 146, CRC Press, 2005.

[65] K. Olu-Le Roy, J. C. Caprais, A. Fifis et al., "Cold-seep assemblages on a giant pockmark off West Africa: spatial patterns and environmental control," Marine Ecology, vol. 28, no. 1, pp. 115-130, 2007.

[66] D. C. Bergquist, T. Ward, E. E. Cordes et al., "Community structure of vestimentiferan-generated habitat islands from Gulf of Mexico cold seeps," Journal of Experimental Marine Biology and Ecology, vol. 289, no. 2, pp. 197-222, 2003.

[67] P. R. Dando, "Biological communities at marine shallowwater vent and seep sites," in The Vent and Seep Biota: Aspects from Microbes to Ecosystems, S. Kiel, Ed., pp. 333378, Springer Netherlands, Dordrecht, 2010.

[68] C. L. van Dover, C. R. German, K. G. Speer, L. M. Parson, and R. C. Vrijenhoek, "Evolution and biogeography of deep-sea vent and seep invertebrates," Science, vol. 295, no. 5558, pp. 1253-1257, 2002.

[69] L. A. Levin, D. W. James, C. M. Martin, A. E. Rathburn, L. H. Harris, and R. H. Michener, "Do methane seeps support distinct macrofaunal assemblages? Observations on community structure and nutrition from the northern California slope and shelf," Marine Ecology Progress Series, vol. 208, pp. 21$39,2000$.

[70] O. Schmale, I. Leifer, C. Stolle et al., "Bubble transport mechanism: indications for a gas bubble-mediated inoculation of benthic methanotrophs into the water column," Continental Shelf Research, vol. 103, pp. 70-78, 2015.

[71] I. Leifer, A. Judd, and J. A. Hildebrand, "Life aquatic chemosynthetic in the photic zone - up the food chain?," Oceanography \& Fisheries, vol. 4, no. 3, article 555636, 2017.
[72] A. F. Bernardino, L. A. Levin, A. R. Thurber, and C. R. Smith, "Comparative composition, diversity and trophic ecology of sediment macrofauna at vents, seeps and organic falls," PLoS ONE, vol. 7, no. 4, article e33515, 2012.

[73] M. R. Cunha, C. F. Rodrigues, L. Génio, A. Hilário, A. Ravara, and O. Pfannkuche, "Macrofaunal assemblages from mud volcanoes in the Gulf of Cadiz: abundance, biodiversity and diversity partitioning across spatial scales," Biogeosciences, vol. 10, no. 4, pp. 2553-2568, 2013.

[74] P. R. Dando and M. Hovland, "Environmental effects of submarine seeping natural gas," Continental Shelf Research, vol. 12, no. 10, pp. 1197-1207, 1992.

[75] L. Menot, J. Galéron, K. Olu et al., "Spatial heterogeneity of macrofaunal communities in and near a giant pockmark area in the deep Gulf of Guinea," Marine Ecology, vol. 31, no. 1, pp. 78-93, 2010.

[76] E. E. Cordes, M. R. Cunha, J. Galéron et al., “The influence of geological, geochemical, and biogenic habitat heterogeneity on seep biodiversity," Marine Ecology, vol. 31, no. 1, pp. 51$65,2010$.

[77] K. Guilini, L. A. Levin, and A. Vanreusel, "Cold seep and oxygen minimum zone associated sources of margin heterogeneity affect benthic assemblages, diversity and nutrition at the Cascadian margin (NE Pacific Ocean)," Progress in Oceanography, vol. 96, no. 1, pp. 77-92, 2012.

[78] A. L. Pasulka, L. A. Levin, J. A. Steele, D. H. Case, M. R. Landry, and V. J. Orphan, "Microbial eukaryotic distributions and diversity patterns in a deep-sea methane seep ecosystem," Environmental Microbiology, vol. 18, no. 9, pp. 3022-3043, 2016.

[79] L. A. Levin, W. Ziebis, G. F. Mendoza, V. Growney-Cannon, and S. Walther, "Recruitment response of methane-seep macrofauna to sulfide-rich sediments: an in situ experiment," Journal of Experimental Marine Biology and Ecology, vol. 330, no. 1, pp. 132-150, 2006.

[80] K. Fujikura, T. Yamanaka, P. Y. G. Sumida et al., "Discovery of asphalt seeps in the deep Southwest Atlantic off Brazil," Deep Sea Research Part II: Topical Studies in Oceanography, vol. 146, pp. 35-44, 2017.

[81] C. Canet, R. M. Prol-Ledesma, P. R. Dando et al., "Discovery of massive seafloor gas seepage along the Wagner Fault, northern Gulf of California," Sedimentary Geology, vol. 228, no. 3-4, pp. 292-303, 2010.

[82] J. R. Bourque, C. M. Robertson, S. Brooke, and A. W. J. Demopoulos, "Macrofaunal communities associated with chemosynthetic habitats from the U.S. Atlantic margin: a comparison among depth and habitat types," Deep Sea Research Part II: Topical Studies in Oceanography, vol. 137, pp. 42-55, 2017.

[83] P. H. Davis and R. B. Spies, "Infaunal benthos of a natural petroleum seep: study of community structure," Marine Biology, vol. 59, no. 1, pp. 31-41, 1980.

[84] Z. Pan, L. Zhao, M. C. Boufadel et al., "Impact of mixing time and energy on the dispersion effectiveness and droplets size of oil," Chemosphere, vol. 166, pp. 246-254, 2017.

[85] I. Leifer, T. A. McClimans, S. H. Gjøsund, and E. Grimaldo, "Fluid motions associated with engineered area bubble plumes," Journal of Waterway, Port, Coastal, and Ocean Engineering, vol. 142, no. 2, 2015.

[86] M. Fitzpatrick, K. A. Hansen, and L. D. Webb, Evaluating Past and Future USCG Use of Ohmsett Test Facility: Shearwater Systems, LLC New London United States, 2016. 
[87] Ø. Johansen, H. Rye, and C. Cooper, "DeepSpill--field study of a simulated oil and gas blowout in deep water," Spill Science \& Technology Bulletin, vol. 8, no. 5-6, pp. 433443, 2003.

[88] C. E. Jones, K.-F. Dagestad, Ø. Breivik et al., "Measurement and modeling of oil slick transport," Journal of Geophysical Research: Oceans, vol. 121, no. 10, pp. 7759-7775, 2016.

[89] M. Lennon, S. Babichenko, N. Thomas, V. Mariette, G. Mercier, and A. Lisin, "Detection and mapping of oil slicks in the sea by combined use of hyperspectral imagery and laser-induced fluorescence," in Proceedings European Association of Remote Sensing Laboratories 5, pp. 120-128, Warsaw, Poland, May-June 2006.

[90] I. Leifer, W. J. Lehr, D. Simecek-Beatty et al., "State of the art satellite and airborne marine oil spill remote sensing: application to the BP Deepwater Horizon oil spill," Remote Sensing of Environment, vol. 124, pp. 185-209, 2012.

[91] J. R. Payne and A. A. Allen, "Use of natural oil seeps for evaluation of dispersant application and monitoring techniques," International Oil Spill Conference Proceedings, vol. 2005, no. 1, pp. 241-245, 2005.

[92] P. A. Dickey, “The first oil well," Journal of Petroleum Technology, vol. 11, no. 1, pp. 14-26, 1959.

[93] W. K. Link, "Significance of oil and gas seeps in world oil exploration," AAPG Bulletin, vol. 36, no. 8, pp. 1505-1540, 1952.

[94] A. Grosbard, "Treadwell Wharf in the Summerland, California Oil Field: the first sea wells in petroleum exploration," Oil Industry History, vol. 3, no. 1, pp. 1-62, 2002.

[95] T. Giallonardo and A. Koller, Gaviota Offshore Gas Field, California Division of Oil and Gas, 1978.

[96] J. M. Hunt, Petroleum Geochemistry and Geology, W. H. Freeman, 1995.

[97] M. Bonini, "Interrelations of mud volcanism, fluid venting, and thrust-anticline folding: examples from the external northern Apennines (Emilia-Romagna, Italy)," Journal of Geophysical Research, vol. 112, no. B8, 2007.

[98] J. Boles, S. Horner, and G. Garner, Fault/Fracture Permeability Estimated from Response of a Natural Marine Methane Seep to Underlying Hydrocarbon Production, American Association of Petroleum Geologists Annual Convention and Exhibition, vol. 170, no. article 40505, AAPG, Denver, CO, USA, 2009.

[99] M. G. Coburn and J. M. Gillespie, "A hydrogeologic study to optimize steamflood performance in a giant oilfield: Kern River field, California," AAPG Bulletin, vol. 86, no. 8, pp. 1489-1505, 2002.

[100] J. Whelan, L. Eglinton, L. Cathles III, S. Losh, and H. Roberts, "Surface and subsurface manifestations of gas movement through a N-S transect of the Gulf of Mexico," Marine and Petroleum Geology, vol. 22, no. 4, pp. 479-497, 2005.

[101] M. Bonini, "Fluid seepage variability across the external Northern Apennines (Italy): structural controls with seismotectonic and geodynamic implications," Tectonophysics, vol. 590, pp. 151-174, 2013.

[102] I. Leifer, M. J. Kamerling, B. P. Luyendyk, and D. S. Wilson, "Geologic control of natural marine hydrocarbon seep emissions, Coal Oil Point seep field, California," Geo-Marine Letters, vol. 30, no. 3-4, pp. 331-338, 2010.

[103] M. Hovland and A. Judd, Seabed Pockmarks and Seepages: Impact on Geology, Biology and the Marine Environment, Graham \& Trotman (Kluwer), London, 1988.
[104] A. G. Judd, "The global importance and context of methane escape from the seabed," Geo-Marine Letters, vol. 23, no. 34, pp. 147-154, 2003.

[105] M. Hovland, "On the self-sealing nature of marine seeps," Continental Shelf Research, vol. 22, no. 16, pp. 2387-2394, 2002.

[106] J. M. Hunt, "Generation and migration of petroleum from abnormally pressured fluid compartments," AAPG Bulletin, vol. 74, no. 1, pp. 1-12, 1990.

[107] M. Bonini, F. Tassi, A. A. Feyzullayev, C. S. Aliyev, F. Capecchiacci, and A. Minissale, "Deep gases discharged from mud volcanoes of Azerbaijan: new geochemical evidence," Marine and Petroleum Geology, vol. 43, pp. 450463, 2013.

[108] R. Capozzi, D. Oppo, and M. Taviani, "Cold seepages: an economic tool for hydrocarbon appraisal," AAPG Bulletin, vol. 101, no. 04, pp. 617-623, 2017.

[109] A. Boetius and E. Suess, "Hydrate Ridge: a natural laboratory for the study of microbial life fueled by methane from nearsurface gas hydrates," Chemical Geology, vol. 205, no. 3-4, pp. 291-310, 2004.

[110] L. Naudts, J. Greinert, Y. Artemov et al., "Geological and morphological setting of 2778 methane seeps in the Dnepr paleo-delta, northwestern Black Sea," Marine Geology, vol. 227, no. 3-4, pp. 177-199, 2006.

[111] A. J. Kopf, "Significance of mud volcanism," Reviews of Geophysics, vol. 40, no. 2, article 1005, 2002.

[112] I. Leifer, J. R. Boles, B. P. Luyendyk, and J. F. Clark, "Transient discharges from marine hydrocarbon seeps: spatial and temporal variability," Environmental Geology, vol. 46, no. 8, pp. 1038-1052, 2004.

[113] I. Leifer, E. Solomon, J. Schneider von Deimling, G. Rehder, R. Coffin, and P. Linke, "The fate of bubbles in a large, intense bubble megaplume for stratified and unstratified water: numerical simulations of $22 / 4 \mathrm{~b}$ expedition field data," Marine and Petroleum Geology, vol. 68, pp. 806-823, 2015.

[114] I. Leifer and J. Boles, "Measurement of marine hydrocarbon seep flow through fractured rock and unconsolidated sediment," Marine and Petroleum Geology, vol. 22, no. 4, pp. 551-568, 2005.

[115] I. Leifer and K. Wilson, "The tidal influence on oil and gas emissions from an abandoned oil well: nearshore Summerland, California," Marine Pollution Bulletin, vol. 54, no. 9, pp. 1495-1506, 2007.

[116] W. S. Reeburgh, "Oceanic methane biogeochemistry," Chemical Reviews, vol. 107, no. 2, pp. 486-513, 2007.

[117] J. Greinert, "Monitoring temporal variability of bubble release at seeps: the hydroacoustic swath system GasQuant," Journal of Geophysical Research, vol. 113, no. C7, article C07048, 2008

[118] L. Spulber, G. Etiope, C. Baciu, C. Malos, and Ş. N. Vlad, "Methane emission from natural gas seeps and mud volcanoes in Transylvania (Romania)," Geofluids, vol. 10, no. 4, pp. 463-475, 2010.

[119] M. S. Salmi, H. P. Johnson, I. Leifer, and J. E. Keister, "Behavior of methane seep bubbles over a pockmark on the Cascadia Continental margin," Geosphere, vol. 7, no. 6, pp. 1273-1283, 2011.

[120] I. Leifer and R. K. Patro, "The bubble mechanism for methane transport from the shallow sea bed to the surface: a 
review and sensitivity study," Continental Shelf Research, vol. 22, no. 16, pp. 2409-2428, 2002.

[121] E. A. Solomon, M. Kastner, I. R. MacDonald, and I. Leifer, "Considerable methane fluxes to the atmosphere from hydrocarbon seeps in the Gulf of Mexico," Nature Geoscience, vol. 2, no. 8, pp. 561-565, 2009.

[122] I. MacDonald, Remote Sensing and Sea-Truth Measurements of Methane Flux to the Atmosphere (HYFLUX Project), US Department of Energy, National Energy Technology Laboratory, 2011.

[123] A. Vazquez, I. Leifer, and R. M. Sanchez, "Consideration of the dynamic forces during bubble growth in a capillary tube," Chemical Engineering Science, vol. 65, no. 13, pp. 4046-4054, 2010.

[124] I. Leifer and D. Culling, "Formation of seep bubble plumes in the Coal Oil Point seep field," Geo-Marine Letters, vol. 30, no. 3-4, pp. 339-353, 2010.

[125] T. D. Lorenson, F. D. Hostettler, R. J. Rosenbauer et al., Natural Offshore Oil Seepage and Related Tarball Accumulation on the California Coastline - Santa Barbara Channel and the Southern Santa Maria Basin, Source identification and inventory: USGS Open File Report, 2009.

[126] I. Leifer and J. F. Clark, "Modeling trace gases in hydrocarbon seep bubbles: application to marine hydrocarbon seeps in the Santa Barbara Channel," Russian Journal of Geology and Geophysics - Geologiya I Geofizika, vol. 43, no. 7, pp. 613-621, 2003.

[127] I. Leifer and K. Wilson, "Quantified marine oil emissions with a video-monitored, oil seep-tent," Marine Technology Society Journal, vol. 38, no. 3, pp. 44-53, 2004.

[128] I. Leifer and A. G. Judd, "Oceanic methane layers: the hydrocarbon seep bubble deposition hypothesis," Terra Nova, vol. 14, no. 6, pp. 417-424, 2002.

[129] I. Leifer, H. Jeuthe, S. H. Gjøsund, and V. Johansen, "Engineered and natural marine seep, bubble-driven buoyancy flows," Journal of Physical Oceanography, vol. 39, no. 12, pp. 3071-3090, 2009.

[130] I. Leifer, B. P. Luyendyk, J. Boles, and J. F. Clark, "Natural marine seepage blowout: contribution to atmospheric methane," Global Biogeochemical Cycles, vol. 20, no. 3, article GB3008, 2006.

[131] J. R. Boles, J. F. Clark, I. Leifer, and L. Washburn, “Temporal variation in natural methane seep rate due to tides, Coal Oil Point area, California," Journal of Geophysical Research: Oceans, vol. 106, no. C11, pp. 27077-27086, 2001.

[132] B. P. Boudreau, C. Algar, B. D. Johnson et al., "Bubble growth and rise in soft sediments," Geology, vol. 33, no. 6, pp. 517520, 2005.

[133] P. K. Kannberg, A. M. Tréhu, S. D. Pierce, C. K. Paull, and D. W. Caress, "Temporal variation of methane flares in the ocean above Hydrate Ridge Oregon," Earth and Planetary Science Letters, vol. 368, pp. 33-42, 2013.

[134] P. Di, D. Feng, and D. Chen, "In-situ and on-line measurement of gas flux at a hydrocarbon seep from the northern South China Sea," Continental Shelf Research, vol. 81, pp. 80-87, 2014.

[135] P. G. Mikolaj and J. P. Ampaya, "Tidal effects on the activity of natural submarine oil seeps," Marine Technological Society Journal, vol. 7, pp. 25-28, 1973.

[136] S. E. Ingebritsen and S. A. Rojstaczer, "Geyser periodicity and the response of geysers to deformation," Journal of Geophys- ical Research: Solid Earth, vol. 101, no. B10, pp. 21891-21905, 1996.

[137] S. Hurwitz, R. A. Sohn, K. Luttrell, and M. Manga, "Triggering and modulation of geyser eruptions in Yellowstone National Park by earthquakes, earth tides, and weather," Journal of Geophysical Research: Solid Earth, vol. 119, no. 3, pp. 1718-1737, 2014.

[138] P. J. Fischer, "Natural gas and oil seeps, Santa Barbara Basin, California," in California Offshore Gas, Oil, and Tar Seeps, D. J. Everitts, R. G. Paul, C. F. Eaton, and E. E. Welday, Eds., pp. 1-62, State of California State Lands Commission, Sacramento, CA, USA, 1977.

[139] D. C. Quigley, J. Scott Hornafius, B. P. Luyendyk, R. D. Francis, J. Clark, and L. Washburn, "Decrease in natural marine hydrocarbon seepage near Coal Oil Point, California, associated with offshore oil production," Geology, vol. 27, no. 11, pp. 1047-1050, 1999.

[140] P. J. Fischer and A. J. Stevenson, "Natural hydrocarbon seeps, Santa Barbara basin," in Santa Barbara Channel Area Revisited Field Trip Guidebook, P. J. Fischer, Ed., vol. 3, pp. 1728, American Association of Petroleum Geologists, Tulsa, OK, USA, 1973.

[141] A. J. Sederman and L. F. Gladden, "Transition to pulsing flow in trickle-bed reactors studied using MRI," AIChE Journal, vol. 51, no. 2, pp. 615-621, 2005.

[142] R. Mellors, D. Kilb, A. Aliyev, A. Gasanov, and G. Yetirmishli, "Correlations between earthquakes and large mud volcano eruptions," Journal of Geophysical Research: Solid Earth, vol. 112, no. B4, article B04304, 2007.

[143] S. Planke, H. Svensen, M. Hovland, D. A. Banks, and B. Jamtveit, "Mud and fluid migration in active mud volcanoes in Azerbaijan," Geo-Marine Letters, vol. 23, no. 3-4, pp. 258-268, 2003.

[144] H. Løseth, L. Wensaas, B. Arntsen, N.-M. Hanken, C. Basire, and K. Graue, "1000 m long gas blow-out pipes," Marine and Petroleum Geology, vol. 28, no. 5, pp. 1047-1060, 2011.

[145] M. Hovland, J. V. Gardner, and A. G. Judd, "The significance of pockmarks to understanding fluid flow processes and geohazards," Geofluids, vol. 2, no. 2, pp. 127-136, 2002.

[146] D. Fischer, J. M. Mogollon, M. Strasser et al., "Subduction zone earthquake as potential trigger of submarine hydrocarbon seepage," Nature Geoscience, vol. 6, no. 8, pp. 647-651, 2013.

[147] A. Obzhirov, R. Shakirov, A. Salyuk, E. Suess, N. Biebow, and A. Salomatin, "Relations between methane venting, geological structure and seismo-tectonics in the Okhotsk Sea," Geo-Marine Letters, vol. 24, no. 3, pp. 135-139, 2004.

[148] L. Géli, P. Henry, T. Zitter et al., "Gas emissions and active tectonics within the submerged section of the North Anatolian Fault zone in the Sea of Marmara," Earth and Planetary Science Letters, vol. 274, no. 1-2, pp. 34-39, 2008.

[149] H. Kanamori and E. E. Brodsky, "The physics of earthquakes," Reports on Progress in Physics, vol. 67, no. 8, pp. 1429-1496, 2004.

[150] M. L. Rudolph and M. Manga, "Frequency dependence of mud volcano response to earthquakes," Geophysical Research Letters, vol. 39, no. 14, article L14303, 2012.

[151] İ. Kuşçu, M. Okamura, H. Matsuoka et al., "Seafloor gas seeps and sediment failures triggered by the August 17, 1999 earthquake in the Eastern part of the Gulf of İzmit, Sea of 
Marmara, NW Turkey," Marine Geology, vol. 215, no. 3-4, pp. 193-214, 2005.

[152] I. Leifer, K. Wilson, J. Tarpley et al., "Factors affecting marine hydrocarbon emissions in an area of natural seeps and abandoned oil wells - Summerland, California," International Oil Spill Conference Proceedings, vol. 2005, pp. 849-853, 2005.

[153] W. J. Lehr and D. Simecek-Beatty, "The relation of Langmuir circulation processes to the standard oil spill spreading, dispersion, and transport algorithms," Spill Science \& Technology Bulletin, vol. 6, no. 3-4, pp. 247-253, 2000.

[154] I. Leifer, T. Del Sontro, B. Luyendyk, and K. Broderick, “Time evolution of beach tar, oil slicks, and seeps in the Coal Oil Point seep field, Santa Barbara Channel, California," International Oil Spill Conference Proceedings, vol. 2005, no. 1, pp. 855-860, 2005.

[155] M. J. Olascoaga and G. Haller, "Forecasting sudden changes in environmental pollution patterns," Proceedings of the National Academy of Sciences of the United States of America, vol. 109, no. 13, pp. 4738-4743, 2012.

[156] W. J. Lehr, H. M. Cekirge, R. J. Fraga, and M. S. Belen, "Empirical studies of the spreading of oil spills," Oil and Petrochemical Pollution, vol. 2, no. 1, pp. 7-11, 1984.

[157] J. A. Fay, "The spread of oil slicks on a calm sea," in Oil on the Sea: Proceedings of a Symposium on the Scientific and Engineering Aspects of Oil Pollution of the Sea, D. P. Hoult, Ed., pp. 53-64, Pleum Press, New York, NY, USA, 1971.

[158] M. Fingas, "Oil and Petroleum Evaporation," in Handbook of Oil Spill Science and Technology, M. Fingas, Ed., pp. 207-223, John Wiley \& Sons, Inc., 2015.

[159] S. Ross and I. Buist, "Preliminary laboratory study to determine the effect of emulsification on oil spill evaporation," in Proceedings of the 18th Arctic and Marine Oilspill Program (AMOP) Technical Seminar, pp. 91-99, Alberta, Canada, June 1995.

[160] M. G. Carls, S. D. Rice, and J. E. Hose, "Sensitivity of fish embryos to weathered crude oil: part I. Low-level exposure during incubation causes malformations, genetic damage, and mortality in larval pacific herring (Clupea pallasi)," Environmental Toxicology and Chemistry, vol. 18, no. 3, pp. 481493, 1999.

[161] R. A. Heintz, J. W. Short, and S. D. Rice, "Sensitivity of fish embryos to weathered crude oil: part II. Increased mortality of pink salmon (Oncorhynchus gorbuscha) embryos incubating downstream from weathered Exxon valdez crude oil," Environmental Toxicology and Chemistry, vol. 18, no. 3, pp. 494-503, 1999.

[162] C. E. Hicken, T. L. Linbo, D. H. Baldwin et al., "Sublethal exposure to crude oil during embryonic development alters cardiac morphology and reduces aerobic capacity in adult fish," Proceedings of the National Academy of Sciences of the United States of America, vol. 108, no. 17, pp. 7086-7090, 2011.

[163] R. N. Clark, G. A. Swayze, I. Leifer et al., A Method for Quantitative Mapping of Thick Oil Spills using Imaging Spectroscopy, U.S. Geological Survey Open-File Report 2010-1167, 2010.

[164] M. Fingas and B. Fieldhouse, "Formation of water-in-oil emulsions and application to oil spill modelling," Journal of Hazardous Materials, vol. 107, no. 1-2, pp. 37-50, 2004.

[165] D. Mackay and C. D. McAuliffe, "Fate of hydrocarbons discharged at sea," Oil and Chemical Pollution, vol. 5, no. 1, pp. 1-20, 1989.
[166] R. C. Prince, R. M. Garrett, R. E. Bare et al., "The roles of photooxidation and biodegradation in long-term weathering of crude and heavy fuel oils," Spill Science \& Technology Bulletin, vol. 8, no. 2, pp. 145-156, 2003.

[167] P. Z. Ray, Mechanisms and transients involved in the solar conversion of petroleum films in aquatic systems, [Ph.D. thesis], University of New Orleans, 2014.

[168] A. J. Mearns and D. Simecek-Beatty, "Longer-term weathering - research needs in perspective," Spill Science \& Technology Bulletin, vol. 8, no. 2, pp. 223-227, 2003.

[169] H. Maki, T. Sasaki, and S. Harayama, "Photo-oxidation of biodegraded crude oil and toxicity of the photo-oxidized products," Chemosphere, vol. 44, no. 5, pp. 1145-1151, 2001.

[170] G. A. L. Delvigne and C. E. Sweeney, "Natural dispersion of oil," Oil and Chemical Pollution, vol. 4, no. 4, pp. 281-310, 1988.

[171] K. Lee, "Oil-particle interactions in aquatic environments: influence on the transport, fate, effect and remediation of oil spills," Spill Science \& Technology Bulletin, vol. 8, no. 1, pp. 3-8, 2002

[172] S. A. Thorpe, "Vertical dispersion of oil droplets in strong winds; the Braer oil spill," Marine Pollution Bulletin, vol. 30, no. 11, pp. 756-758, 1995.

[173] K. L. Daly, U. Passow, J. Chanton, and D. Hollander, "Assessing the impacts of oil-associated marine snow formation and sedimentation during and after the Deepwater Horizon oil spill," Anthropocene, vol. 13, pp. 18-33, 2016.

[174] J. Michel and K. A. Hansen, "Chapter 13 - sunken and submerged oil," in Oil Spill Science and Technology (Second Edition), M. F. Fingas, Ed., pp. 731-758, Gulf Professional Publishing, Cambridge, MA, USA, 2017.

[175] N. Das and P. Chandran, "Microbial degradation of petroleum hydrocarbon contaminants: an overview," Biotechnology Research International, vol. 2011, Article ID 941810, 13 pages, 2011.

[176] R. Atlas and J. Bragg, "Bioremediation of marine oil spills: when and when not - the Exxon Valdez experience," Microbial Biotechnology, vol. 2, no. 2, pp. 213-221, 2009.

[177] D. Ghosal, S. Ghosh, T. K. Dutta, and Y. Ahn, "Current state of knowledge in microbial degradation of polycyclic aromatic hydrocarbons (PAHs): a review," Frontiers in Microbiology, vol. 7, article 1369, 2016.

[178] NOAA, Trajectory Analysis Handbook, NOAA Ocean Service, Office of Response and Restoration, Seattle, WA, USA, 2002.

[179] R. J. Sobey and C. H. Barker, "Wave-driven transport of surface oil," Journal of Coastal Research, vol. 13, no. 2, pp. 490496, 1997.

[180] P. E. Russell and D. A. Huntley, "A cross-shore transport "shape function" for high energy beaches," Journal of Coastal Research, vol. 15, no. 1, pp. 198-205, 1999.

[181] I. J. Mariño-Tapia, P. E. Russell, T. J. O'Hare, M. A. Davidson, and D. A. Huntley, "Cross-shore sediment transport on natural beaches and its relation to sandbar migration patterns: 1. Field observations and derivation of a transport parameterization," Journal of Geophysical Research: Oceans, vol. 112, no. C3, article C03001, 2007.

[182] D. C. Conley and R. A. Beach, "Cross-shore sediment transport partitioning in the nearshore during a storm event," Journal of Geophysical Research: Oceans, vol. 108, no. C3, article 3065, 2003. 
[183] T. Butt and P. Russell, "Hydrodynamics and cross-shore sediment transport in the swash-zone of natural beaches: a review," Journal of Coastal Research, vol. 16, no. 2, pp. 255268, 2000.

[184] B. Castelle, T. Scott, R. W. Brander, and R. J. McCarroll, "Rip current types, circulation and hazard," Earth-Science Reviews, vol. 163, pp. 1-21, 2016.

[185] Y. Kuriyama, Y. Ito, and S. Yanagishima, "Cross-shore variation of long-term average longshore current velocity in the nearshore zone," Continental Shelf Research, vol. 28, no. 3, pp. 491-502, 2008.

[186] W. Harrison, "Empirical equation for longshore current velocity," Journal of Geophysical Research, vol. 73, no. 22, pp. 6929-6936, 1968.

[187] M. S. Longuet-Higgins, "Longshore currents generated by obliquely incident sea waves: 1," Journal of Geophysical Research, vol. 75, no. 33, pp. 6778-6789, 1970.

[188] P. S. Dalyander, J. W. Long, N. G. Plant, and D. M. Thompson, "Assessing mobility and redistribution patterns of sand and oil agglomerates in the surf zone," Marine Pollution Bulletin, vol. 80, no. 1-2, pp. 200-209, 2014.

[189] T. S. Del Sontro, I. Leifer, B. P. Luyendyk, and B. R. Broitman, "Beach tar accumulation, transport mechanisms, and sources of variability at Coal Oil Point, California," Marine Pollution Bulletin, vol. 54, no. 9, pp. 1461-1471, 2007.

[190] T. S. Del Sontro, Beach asphalt (tar) accumulation at Coal Oil Point, CA: identification of processes controlling temporal variations, [M.S. thesis], University of California, Santa Barbara, CA, USA, 2006.

[191] B. Hartman and D. E. Hammond, "The use of carbon and sulfur isotopes as correlation parameters for the source identification of beach tar in the southern California borderland," Geochimica et Cosmochimica Acta, vol. 45, no. 3, pp. 309319, 1981.

[192] J. R. Boles, P. Eichhubl, G. Garven, and J. Chen, "Evolution of a hydrocarbon migration pathway along basin-bounding faults: evidence from fault cement," AAPG Bulletin, vol. 88, no. 7, pp. 947-970, 2004.

[193] R. Arnold, Geology and Oil Resources of the Summerland District, USGS, Santa Barbara County, CA USA, 1907.

[194] T. J. Braje, J. M. Erlandson, and J. Timbrook, "An asphaltum coiled basket impression, tarring pebbles, and Middle Holocene water bottles from San Miguel Island, California," Journal of California and Great Basin Anthropology, vol. 25, no. 2, pp. 207-213, 2005.

[195] K. M. Brown, J. Connan, N. W. Poister, R. L. Vellanoweth, J. Zumberge, and M. H. Engel, "Sourcing archaeological asphaltum (bitumen) from the California Channel Islands to submarine seeps," Journal of Archaeological Science, vol. 43, pp. 66-76, 2014.

[196] K. M. Brown, "Asphaltum (bitumen) production in everyday life on the California Channel Islands," Journal of Anthropological Archaeology, vol. 41, pp. 74-87, 2016.

[197] F. F. Latta, Handbook of Yokuts Indians, Bear State Books, Exeter, CA, USA, 1949.

[198] E. R. Wilkinson, California Offshore Oil and Gas Seeps, California Divison of Oil, Gas, and Geothermal Resources, 1972.

[199] R. J. Behl, "Since Bramlette (1946): the Miocene Monterey Formation of California revisited," in Special Paper 338: Classic Cordilleran Concepts: A View from California, pp. 301-313, Geological Society of America, 1999.
[200] T. C. MacKinnon, Petroleum Geology of the Monterey Formation in the Santa Maria and Santa Barbara Coastal and Offshore Areas, Oil in the Monterey California Formation Los Angeles to Santa Maria, California July 20-24, 1989, American Geophysical Union, 2013.

[201] P. Eichhubl, H. G. Greene, T. Naehr, and N. Maher, "Structural control of fluid flow: offshore fluid seepage in the Santa Barbara Basin, California," Journal of Geochemical Exploration, vol. 69-70, pp. 545-549, 2000.

[202] T. L. Davis and J. S. Namson, "Field excursion: petroleum traps and structures along the San Andreas convergent strike-slip plate boundary, California," AAPG Bulletin, vol. 101, no. 4, pp. 607-615, 2017.

[203] M. Kamerling, S. Horner, and L. Thompson, "The Monterey Formation at South Ellwood Field, Santa Barbara Channel, California," in Proceedings Society of Petroleum Engineers Western Regional / AAPG Pacific Section Joint Meeting, Long Beach, California, Bakersfield, CA, USA, May 2003.

[204] D. J. Olsen, Surface and Subsurface Geology of the Santa Barbara Goleta Metropolitan Area, Santa Barbara County, California, [M.S. thesis], Oregon State University, 1982.

[205] T. Finkbeiner, C. A. Barton, and M. D. Zoback, "Relationships among in-situ stress, fractures and faults, and fluid flow: Monterey formation, Santa Maria Basin, California," AAPG Bulletin, vol. 81, no. 12, pp. 1975-1999, 1997.

[206] W. L. Bartlett, "Elwood Oil Field Santa Barbara County, California," in Proceedings Structure and Petroleum Geology, Santa Barbara Channel, California, pp. 217-237, Ventura, CA, USA, 1998.

[207] M. Duffy, F. S. Kinnaman, D. L. Valentine, E. A. Keller, and J. F. Clark, "Gaseous emission rates from natural petroleum seeps in the Upper Ojai Valley, California," Environmental Geosciences, vol. 14, no. 4, pp. 197-207, 2007.

[208] I. Leifer and K. Wilson, Santa Paula Creek Seep SSEP: Vol 1, Department of Fish and Wildlife-Oil Spill Prevention Response, 2015, http://www.dfg.ca.gov/ospr/Science/ SSEPReportsPublications.aspx.

[209] T. D. Lorenson, I. Leifer, F. L. Wong et al., Biomarker Chemistry and Flux Quantification Methods for Natural Petroleum Seeps and Produced Oils, Offshore Southern California, US Geological Survey Scientific Investigations Report: US Geological Survey, BOEM 2011-016, 2011.

[210] T. D. Lorenson, F. L. Wong, P. Dartnell, and R. W. Sliter, "Greenhouse gases generated from the anaerobic biodegradation of natural offshore asphalt seepages in southern California," Geo-Marine Letters, vol. 34, no. 2-3, pp. 281295, 2014

[211] J. W. Vernon and R. A. Slater, "Submarine tar mounds, Santa Barbara County, California," AAPG Bulletin, vol. 47, no. 8, pp. 1624-1627, 1963.

[212] D. Weber, B. A. Marquez, C. Taylor et al., "Macroseepage of methane and light alkanes at the La Brea tar pits in Los Angeles," Journal of Atmospheric Chemistry, vol. 74, no. 3, pp. 339-356, 2017.

[213] G. Etiope, L. A. Doezema, and C. Pacheco, "Emission of methane and heavier alkanes from the La Brea Tar Pits seepage area, Los Angeles," Journal of Geophysical Research: Atmospheres, vol. 122, no. 21, pp. 12,008-12,019, 2017.

[214] P. Farrell, D. Culling, and I. Leifer, "Transcontinental methane measurements: part 1. A mobile surface platform for 
source investigations," Atmospheric Environment, vol. 74, pp. 422-431, 2013.

[215] Y.-K. Hsu, T. VanCuren, S. Park et al., "Methane emissions inventory verification in Southern California," Atmospheric Environment, vol. 44, no. 1, pp. 1-7, 2010.

[216] J. Peischl, T. B. Ryerson, J. Brioude et al., "Quantifying sources of methane using light alkanes in the Los Angeles basin, California," Journal of Geophysical Research: Atmospheres, vol. 118, no. 10, pp. 4974-4990, 2013.

[217] P. O. Wennberg, W. Mui, D. Wunch et al., "On the sources of methane to the Los Angeles atmosphere," Environmental Science \& Technology, vol. 46, no. 17, pp. 9282-9289, 2012.

[218] W. E. Crain, W. E. Mero, and D. Patterson, "Geology of the Point Arguello discovery," AAPG Bulletin, vol. 69, no. 4, pp. 537-595, 1985.

[219] P. A. Jackson and R. S. Yeats, "Structural evolution of Carpinteria Basin, western Transverse Ranges, California," AAPG Bulletin, vol. 66, no. 7, pp. 805-829, 1982.

[220] P. W. Prutzman, Petroleum in Southern California, California State Mining Bureau, Sacramento, CA, USA, 1913.

[221] B. H. Hesson and H. R. Olilang, Seal Beach Oil Field: Alamitos and Marine Areas, Department of Conservations, Division of Oil and Gas, 1990.

[222] F. D. Hostettler, R. J. Rosenbauer, T. D. Lorenson, and J. Dougherty, "Geochemical characterization of tarballs on beaches along the California coast: part I - Shallow seepage impacting the Santa Barbara Channel Islands, Santa Cruz, Santa Rosa and San Miguel," Organic Geochemistry, vol. 35, no. 6, pp. 725-746, 2004.

[223] I. Leifer and K. Wilson, "Santa Paula Creek Seep SSEP," in Bird Oiling: Oil Spill Prevention and Response, vol. 2, California Department of Fish and Wildlife, 2017.

[224] H. Tsuge, S. Hibino, and U. Nojima, "Volume of a bubble formed at a single submerged orifice in a flowing liquid," International Chemical Engineering, vol. 21, no. 4, pp. 630-636, 1981.

[225] R. B. Spies and P. H. Davis, "The infaunal benthos of a natural oil seep in the Santa Barbara Channel," Marine Biology, vol. 50, no. 3, pp. 227-237, 1979.

[226] J. F. Clark, L. Washburn, and K. S. Emery, "Variability of gas composition and flux intensity in natural marine hydrocarbon seeps," Geo-Marine Letters, vol. 30, no. 3-4, pp. 379-388, 2010.

[227] H. Nunn, "The 1925 Santa Barbara earthquake: Herbert Nunn's account," Bulletin of the Seismological Society of America, vol. 15, pp. 308-319, 1925.

[228] P. Jokuty, S. Whiticar, Z. Wang, B. Fieldhouse, and M. Fingas, A Catalogue of Crude Oil and Oil Product Properties for the Pacific Region, Environment Canada, Ottawa, ON, USA, 1999.

[229] C. E. Dorman and C. D. Winant, "The structure and variability of the marine atmosphere around the Santa Barbara Channel," Monthly Weather Review, vol. 128, no. 2, pp. 261-282, 2000.

[230] E. H. Beckenbach, Surface circulation in the Santa Barbara Channel: an application of high frequency radar for descriptive physical oceanography in the coastal zone, [Ph.D. thesis], University of California, Santa Barbara, CA, USA, 2004.

[231] R. Lu and R. P. Turco, "Air pollutant transport in a coastal environment-II. Three-dimensional simulations over Los Angeles Basin,” Atmospheric Environment, vol. 29, no. 13, pp. 1499-1518, 1995.
[232] C. Jones, F. Fujioka, and L. M. V. Carvalho, "Forecast skill of synoptic conditions associated with Santa Ana Winds in Southern California," Monthly Weather Review, vol. 138, no. 12, pp. 4528-4541, 2010.

[233] C. N. Cudaback, L. Washburn, and E. Dever, "Subtidal innershelf circulation near Point Conception, California," Journal of Geophysical Research: Oceans, vol. 110, no. C10, article C10007, 2005.

[234] J. M. Wilczak, W. F. Dabberdt, and R. A. Kropfli, "Observations and numerical model simulations of the atmospheric boundary layer in the Santa Barbara Coastal region," Journal of Applied Meteorology, vol. 30, no. 5, pp. 652-673, 1991.

[235] M. Hughes and A. Hall, "Local and synoptic mechanisms causing Southern California's Santa Ana winds," Climate Dynamics, vol. 34, no. 6, pp. 847-857, 2010.

[236] R. L. Kolpack, "Relationship of migration of natural seep material to oceanography of Santa Barbara Channel," in California Offshore Gas, Oil, and Tar Seeps, D. J. Everitts, R. G. Paul, C. F. Eaton, and E. E. Welday, Eds., pp. 225255, State Lands Commission, State of California, Sacramento, CA, USA, 1977.

[237] C. D. Winant, E. P. Dever, and M. C. Hendershott, "Characteristic patterns of shelf circulation at the boundary between central and southern California," Journal of Geophysical Research: Oceans, vol. 108, no. C2, article 3021, 2003.

[238] T. McClimans, I. Leifer, S. H. Gjøsund, E. Grimaldo, P. Daling, and F. Leirvik, "Pneumatic oil barriers: the promise of area bubble plumes," Proceedings of the Institution of Mechanical Engineers, Part M: Journal of Engineering for the Maritime Environment, vol. 227, no. 1, pp. 22-38, 2013.

[239] C. Farwell, C. M. Reddy, E. Peacock, R. K. Nelson, L. Washburn, and D. L. Valentine, "Weathering and the fallout plume of heavy oil from strong petroleum seeps near Coal Oil Point, CA," Environmental Science \& Technology, vol. 43, no. 10, pp. 3542-3548, 2009.

[240] A. L. Alldredge and C. Gotschalk, "In situ settling behavior of marine snow," Limnology and Oceanography, vol. 33, no. 3, pp. 339-351, 1988.

[241] C. Ohlmann, Santa Barbara Channel Inner-Shelf Study: University of California, Santa Barbara, University of California, Santa Barbara, CA, USA, 2007, https://icess.eri.ucsb.edu/ drifter/SBCIS/index.php.

[242] J. E. Estes, R. E. Crippen, and J. L. Star, "Natural oil seep detection in the Santa Barbara Channel, California, with shuttle imaging radar," Geology, vol. 13, no. 4, pp. 282-284, 1985.

[243] S. A. Thorpe, "Langmuir circulation and the dispersion of oil spills in shallow seas," Spill Science \& Technology Bulletin, vol. 6, no. 3-4, pp. 213-223, 2000.

[244] R. C. Mertz, Determination of the quantity of oil substances on beaches and in nearshore waters, State Water Pollution Control Board, Sacramento, CA, USA, 1959.

[245] N. C. Kraus, M. Isobe, H. Igarashi, T. O. Sasaki, and K. Horikawa, "Field experiments on longshore sand transport in the surf zone," in 18th International Conference on Coastal Engineering, pp. 969-988, Cape Town, South Africa, November 1982.

[246] H. Coleman, Ecological consequences of chronic marine oil contamination, [Ph.D. thesis], University of California, Santa Barbara, CA, USA, 2009.

[247] P. A. Montagna, J. E. Bauer, M. C. Prieto, D. Hardin, and R. B. Spies, "Benthic metabolism in a natural coastal petroleum 
seep," Marine Ecology Progress Series, vol. 34, pp. 31-40, 1986.

[248] R. B. Spies, J. J. Stegeman, D. E. Hinton et al., "Biomarkers of hydrocarbon exposure and sublethal effects in embiotocid fishes from a natural petroleum seep in the Santa Barbara Channel," Aquatic Toxicology, vol. 34, no. 3, pp. 195-219, 1996.

[249] R. B. Spies and D. J. Desmarais, "Natural isotope study of trophic enrichment of marine benthic communities by petroleum seepage," Marine Biology, vol. 73, no. 1, pp. 67-71, 1983.

[250] E. E. Cordes, D. C. Bergquist, and C. R. Fisher, "Macro-ecology of Gulf of Mexico cold seeps," Annual Review of Marine Science, vol. 1, no. 1, pp. 143-168, 2009.

[251] K. Hylland, "Polycyclic aromatic hydrocarbon (PAH) ecotoxicology in marine ecosystems," Journal of Toxicology and Environmental Health, Part A, vol. 69, no. 1-2, pp. 109-123, 2006.

[252] M. Shahidul Islam and M. Tanaka, "Impacts of pollution on coastal and marine ecosystems including coastal and marine fisheries and approach for management: a review and synthesis," Marine Pollution Bulletin, vol. 48, no. 7-8, pp. 624-649, 2004.

[253] C. Sheppard, M. Al-Husiani, F. Al-Jamali et al., "The Gulf: a young sea in decline," Marine Pollution Bulletin, vol. 60, no. 1, pp. 13-38, 2010.

[254] J. M. Teal and R. W. Howarth, "Oil spill studies: a review of ecological effects," Environmental Management, vol. 8, no. 1, pp. 27-43, 1984.

[255] C. H. Peterson, S. D. Rice, J. W. Short et al., "Long-term ecosystem response to the Exxon Valdez Oil Spill," Science, vol. 302, no. 5653, pp. 2082-2086, 2003.

[256] I. Leifer, J. F. Clark, B. Luyendyk, and D. Valentine, "Identifying future directions for subsurface hydrocarbon migration research," Eos, Transactions American Geophysical Union, vol. 84, no. 37, pp. 364-371, 2003.

[257] M. Fingas and C. E. Brown, "A review of oil spill remote sensing," Sensors, vol. 18, no. 2, p. 91, 2018.

[258] WESTCARB, Status of Sedimentary Basins in California, West Coast Regional Carbon Sequestration Partnership, Berkeley, CA, USA, 2011, http://gif.berkeley.edu/westcarb/ images/maps/CA_basins_status.pdf.

[259] CDOG, California Oil and Gas Fields Volume II - Southern, Central Coastal, and Offshore California Oil and Gas Fields (CD-1), California Division of Oil and Gas, 1992.

[260] S. J. Hornafius, B. P. Luyendyk, and M. J. Kamerling, Seismic Mapping of the North Channel Fault Near Santa Barbara, CA, Geological Society of America, 1996.

[261] D. L. Divins and D. Metzger, NGDC Coastal Relief Model, Southern California Coastal Ocean Observing System, 2017. 

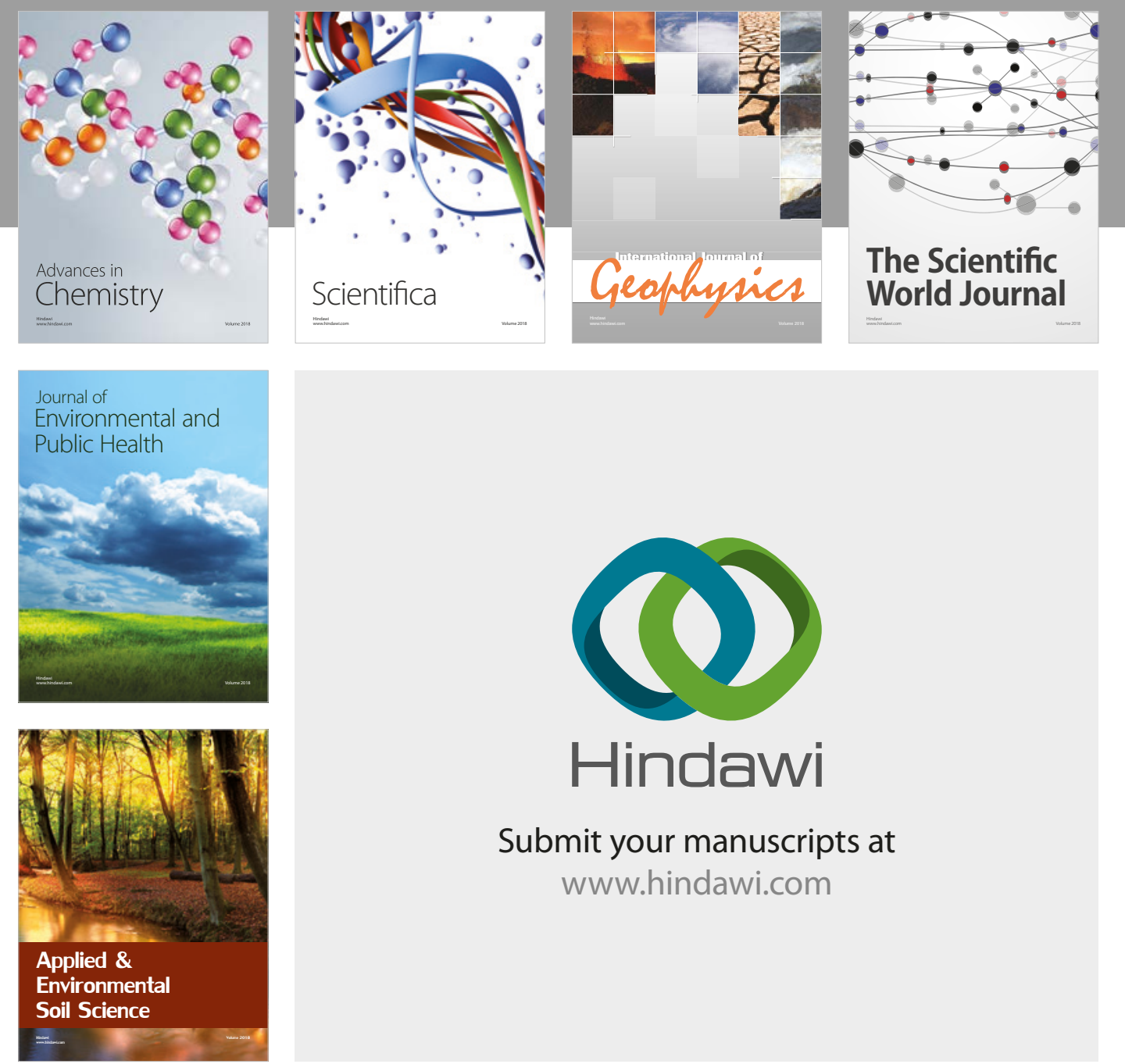

The Scientific

\section{World Journal}
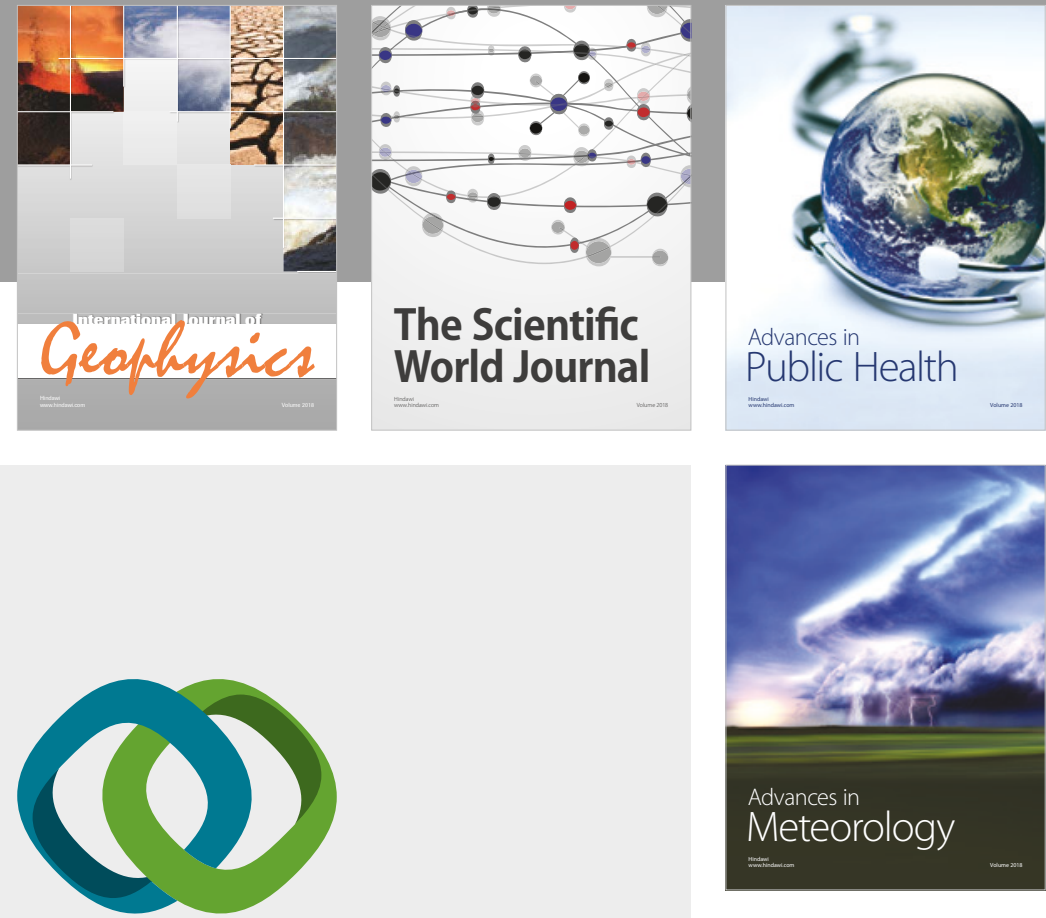

Advan

Public Health

\section{Hindawi}

Submit your manuscripts at

www.hindawi.com
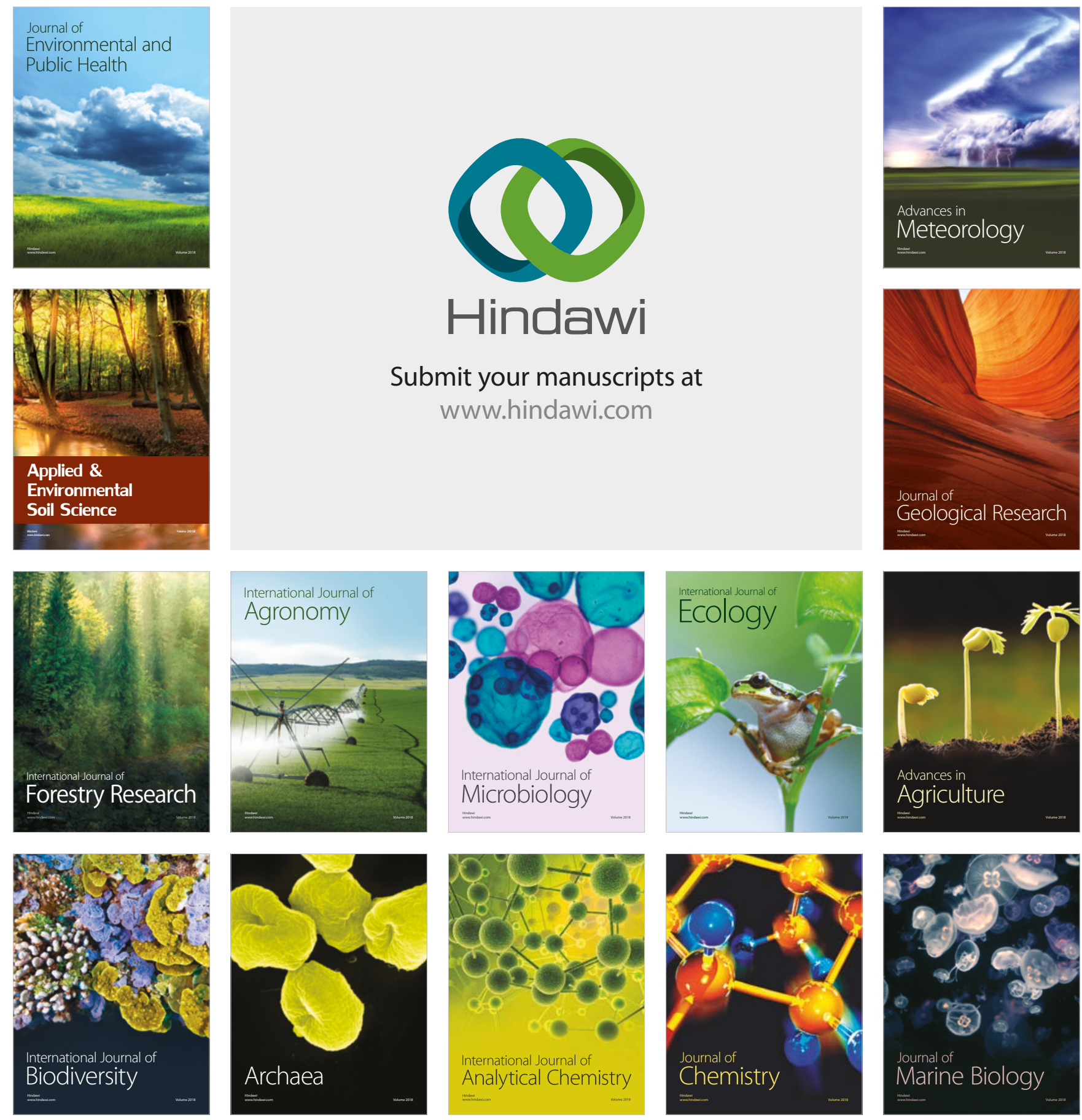